Universidade de São Paulo

Faculdade de Medicina de Ribeirão Preto

Departamento de Genética

\title{
A IMUNOMODULAÇÃO EXERCIDA POR RECEPTORES DO TIPO TOLL EM CÉLULAS-TRONCO MESENQUIMAIS
}

Bruno Braga Sangiorgi 
Universidade de São Paulo

Faculdade de Medicina de Ribeirão Preto

Departamento de Genética

Bruno Braga Sangiorgi

\section{A IMUNOMODULAÇÃO EXERCIDA POR RECEPTORES DO TIPO TOLL EM CÉLULAS-TRONCO MESENQUIMAIS}

Dissertação apresentada ao Programa de PósGraduação em Genética da Faculdade de Medicina de Ribeirão Preto da Universidade de São Paulo, como parte dos pré-requisitos para obtenção do título de Mestre em Ciências.

Área de concentração: Genética

Orientador: Dr. Rodrigo Alexandre Panepucci 
AUTORIZO A DIVULGAÇÃO TOTAL OU PARCIAL DESTE TRABALHO, POR QUALQUER MEIO CONVENCIONAL OU ELETRÔNICO, PARA FINS DE ESTUDO OU PESQUISA, DESDE QUE CITADA A FONTE.

FICHA CATALOGRÁFICA

Sangiorgi, Bruno Braga.

A imunomodulação exercida por receptores do tipo Toll em células-tronco mesenquimais.

Ribeirão Preto, 2014.

Dissertação de Mestrado, apresentada à Faculdade de Medicina de Ribeirão Preto/USP. Área de concentração: Genética

Orientador: Panepucci, Rodrigo Alexandre.

1. Células-tronco mesenquimais. 2. Imunomodulação.

3. Receptores do tipo Toll. 4. Via NF-кB. 


\section{FOLHA DE APROVAÇÃO}

Bruno Braga Sangiorgi

\section{A imunomodulação exercida por receptores do tipo Toll em células-tronco mesenquimais}

Dissertação apresentada a Faculdade de Medicina de Ribeirão Preto da Universidade de São Paulo para obtenção do título de Mestre em Ciências.

Área de concentração: Genética

Aprovado em:

\section{Banca examinadora:}

Prof. Dr. Rodrigo Alexandre Panepucci

Instituição:

Assinatura:

Prof. Dr.

Instituição:

Assinatura:

Prof. Dr.

Instituição:

Assinatura: 


\section{AGRADECIMENTOS}

Gostaria de agradecer primeiramente ao meu orientador, o Prof. Dr. Rodrigo Alexandre Panepucci, por sua confiança em meu potencial de conduzir o presente estudo, e também por sua participação ativa, com ideias e discussões relevantes para a realização deste trabalho.

Aos meus amigos do laboratório de Hemalogia: Danuta Sastre, Felipe Canto, Helder Freitas, Ildercílio Lima, Josiane Sciavinato, Lara Zapatta, Mariane Fráguas, Rodrigo Haddad, Sarah Blima e Vitor Leão, pelo companheirismo e participação.

Às técnicas do laboratório de Biologia Molecular I e Hematologia: Amélia Góes, Cláudia Avelar, Elizabete Tavares, Marli Tavella e Júlia Mieko.

À Susie Nalon, secretária do departamento de genética da Faculdade de Medicina de Ribierão Preto, pela boa vontade e paciência.

À minha família, pelo grande apoio que tenho recebido.

À Maria Luiza Prudente de Oliveira, pelo companheirismo apresentado durante toda condução deste trabalho.

À CAPES, pela bolsa concedida, a FAEPA e ao Hemocentro pelo auxílio financeiro junto a eventos científicos.

E a todos os demais que contribuíram de forma direta ou indireta para a realização deste trabalho. 
“A ciência é a melhor ferramenta já concebida para o entendimento de como o mundo funciona"

Michael Shermer 


\section{RESUMO}

Sangiorgi, B. A imunomodulação exercida por receptores do tipo Toll em células-tronco mesenquimais. Dissertação de Mestrado - Faculdade de Medicina de Ribeirão Preto, Universidade de São Paulo, Ribeirão Preto, 2014.

Diversos estudos tem demonstrado que as células-tronco mesenquimais (CTM) são imbuídas de uma forte atividade imunossupressora in vitro, no entanto, os resultados de imunoterapias utilizando CTM têm sido variáveis até o momento. Nossa hipótese para tal variação são interações que devem ocorrer entre as CTM e fragmentos de patógenos circulantes nos pacientes, resultando na modulação da atividade imunossupressora. Para avaliar a ocorrência deste fenômeno em CTM de medula óssea, inicialmente foi avaliado a presença de diversos TLR através da marcação com anticorpos e posterior quantificação por citometria de fluxo, sendo observada a presença dos TLR2, TLR3, TLR4 e TLR9. No intuito de avaliar alterações no potencial imunossupressor, linfócitos $\mathrm{T}$ ativados e marcados a nível intracelular foram cocultivados com CTM estimuladas com LPS, POLY IC e oligonucleotídeos com motivos CpG: DSP30, CpG-A e CpG-B, sendo sua proliferação quantificada por citometria de fluxo. Como resultados, foi observado que a estimulação com LPS e DSP30 levaram a perda e acentuação da capacidade supressora, respectivamente, enquanto o estímulo simultâneo com LPS e DSP30 resultou em sua manutenção. Tais modulações na imunossupressão foram corroboradas ao serem avaliadas modulações na expressão gênica, tendo em vista que o estímulo por LPS e DSP30 induziram no aumento da expressão de IL1 $\beta$ e TGF $\beta$, respectivamente. Em seguida, foi avaliado o efeito das mesmas condições experimentais na indução a proliferação das CTM, ao ser mensurada alterações na quantidade de células em um equipamento de High content Screening (HCS). Como resultados, foi possível observar que somente o tratamento com DSP30 foi capaz de aumentar significativamente a quantidade de células, fenômeno corroborado ao ser mensurada a síntese de DNA, através da utilização de um produto comercial, seguido de análise por citometria de fluxo. No intuito de avaliar possíveis modulações na via NF- $\mathrm{B}$, CTM estimuladas com LPS ou DSP30 foram sujeitas ao ensaio de imunoprecipitação de cromatina, utilizando anticorpos específicos a subunidades de RelA e RelB, sendo o DNA imunoprecipitado sujeito a PCR quantitativo com primers específicos para a regiões promotoras do gene VCAM-1. Como resultados, foi observado que o estímulo com LPS aumentou a atividade do RelA, enquanto não foram observados efeitos após o estímulo com DSP30. No entanto, o estímulo simultâneo com ambos os ligantes levou ao aumento de atividade de RelA e RelB. Ao serem avaliadas estas condições em um ensaio de imunofluorescência analisado em HCS, foi possível observar maiores níveis da proteína RelB no citoplasma das células tratadas com DSP30, sugerindo um aumento da sua formação. Apesar dos mecanismos moleculares subjacentes aos resultados observados ainda necessitarem de maior elucidação, nosso trabalho indica que a estimulação das CTM com DSP30 pode trazer benefícios no sentido de potencializar a imunossupressão e proliferação celular, além de impedir a perda da imunossupressão, decorrente da interação com LPS. Tais resultados poderão servir como diretrizes para o aprimoramento de imunoterapias utilizando CTM de medula óssea, principalmente em casos de pacientes com infecções por patógenos.

Palavras-chaves: Células-tronco mesenquimais; Imunomodulação; Receptores do tipo Toll; Via NF- $\kappa$ B. 


\begin{abstract}
Sangiorgi, B. The Immunomodulation of toll-like receptors on mesenchymal stem cells. Faculdade de Medicina de Ribeirão Preto, Universidade de São Paulo, Ribeirão Preto, 2014.

Several studies have shown that mesenchymal stem cells (MSC) are imbued with a strong immunosuppressive activity in vitro, however, the results of immunotherapies using MSC have been varied so far. Our hypothesis for such variations are interactions that may occur between MSC and fragments of circulating pathogens in patients, resulting in the modulation of the immunosuppressive activity. To evaluate the occurrence of this phenomenon in bone marrow MSC, the presence of various TLR was initially evaluated by labeling with antibodies and subsequent quantification by flow cytometry, being observed the presence of TLR2, TLR3, TLR4 and TLR9. In order to measure changes in the immunosuppressive potential, activated $\mathrm{T}$ cells labeled at intracellular level were co-cultured with MSC stimulated with LPS, POLY IC and oligonucleotides with CpG motifs: DSP30, CpG-A and CpG-B, being their proliferation quantified by flow cytometry. As a result, it was observed that stimulation with LPS and DSP30 hampered and enhanced the immunosuppressive capacity, respectively, while simultaneous stimulation with LPS and DSP30 resulted in the maintenance of this capacity. Such modulations on immunosuppression were corroborated when assessing modulation in gene expression, as seemed by LPS and DSP30 stimulation lead to an increase on expression of IL1 $\beta$ e TGF $\beta$, respectively. Thereafter, the effect of the same experimental conditions were evaluated in its capacity to induce MSC proliferation, being measured the changes in cells amount on a High Content Screening (HCS) device. As a result, it was observed that only the DSP30 stimulation was able to significantly increase the amount of cells, which was confirmed when measured the DNA synthesis using a commercial product, followed by analysis by flow cytometry. In order to evaluate possible modulations in NF-kB pathway, MSC stimulated with LPS or DSP30 were subjected to Chromatin Immunoprecipitation assay using antibodies against subunits RelA and RelB, being the immunoprecipitated DNA subjected to quantitative PCR with primers specific to the regions VCAM-1 promoter gene. As a result, it was observed that stimulation with LPS increased the activity of RelA, while no effects were observed after stimulation with DSP30. However, simultaneous stimulation with both ligands led to increased activity of RelA and RelB. When those conditions were evaluated by an immunofluorescence assay, followed by analysis on HCS, was possible to observe a higher level of RelB at cytoplasm DSP30 treated cells, suggesting an increase in its production. Although the molecular mechanisms underlying the observed results still require further elucidation, our work indicates that stimulation of MSC with DSP30 can bring benefits in terms of enhancing immunosuppression, cell proliferation and prevent the loss of immunosuppression caused by LPS stimulation. These results may serve as guidelines for the improvement of immunotherapies using MSC bone marrow, especially in cases of patients with infections caused by pathogens.
\end{abstract}

Keywords: Mesenchymal stem cells; immunomodulation; Toll-like receptors; NF- $\mathrm{B}$ pathway. 


\section{SUMÁRIO}

1. INTRODUÇÃ

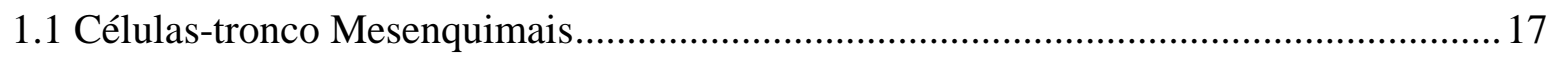

1.2 A imunorregulação mediada por células-tronco mesenquimais ..................................21

1.3 A imunomodulação excercida por receptores do tipo Toll ........................................25

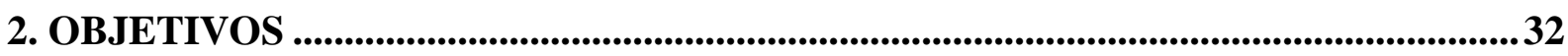

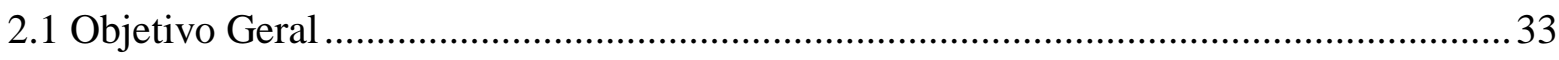

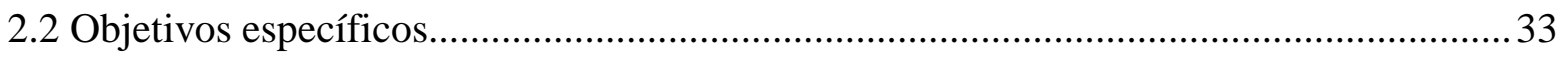

3. MATERIAIS E MÉTODOS .....................................................................................34

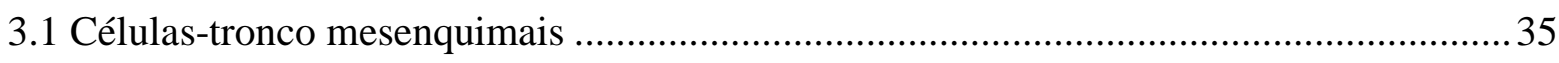

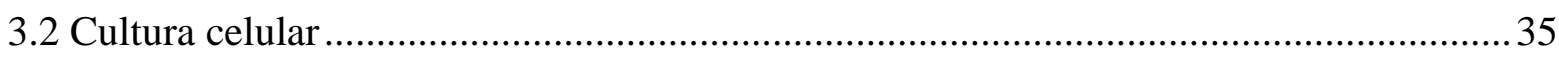

3.3 Obtenção das Células Mononucleares do Sangue Periférico (PBMC) ............................36

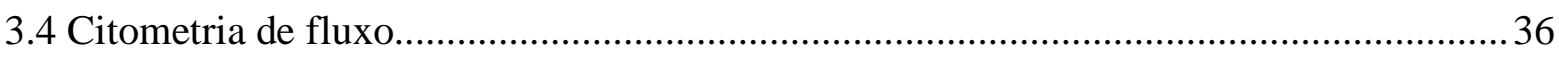

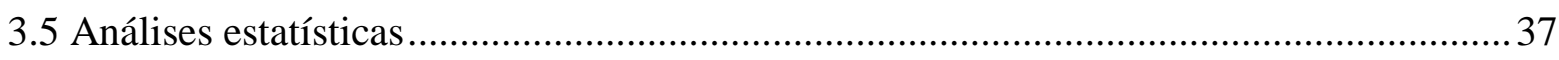

3.6 Avaliação da expressão de receptores do tipo Toll a níveis proteicos. ............................37

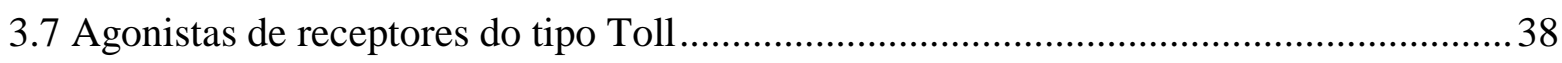

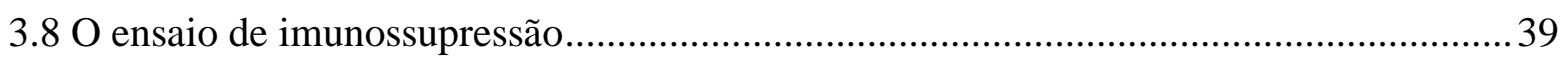

3.9 Estimulação das células-tronco mesenquimais com agonistas de TLR ..........................40

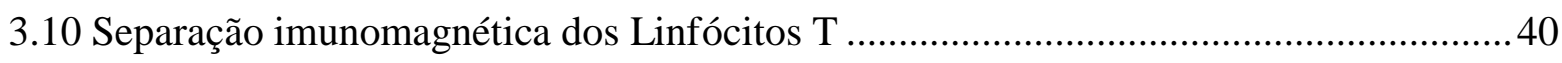

3.11 Marcação intracelular dos linfócitos T .................................................................... 41

3.12 Ativação de linfócitos T e co-cultivo com células-tronco mesenquimais......................42

3.13 Avaliação da imunossupressão exercida por células-tronco mesenquimais ..................44

3.14 Avaliação de alterações na proliferação celular - High Content Screening (HCS) .......46

3.15 Avaliação de alterações na proliferação celular - Síntese de DNA ..............................47

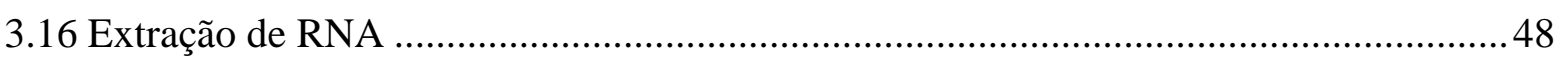

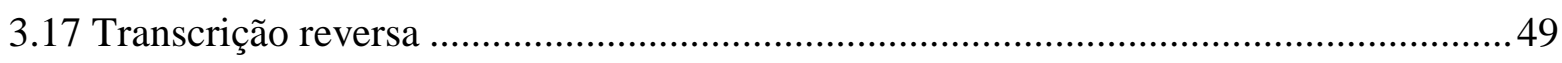

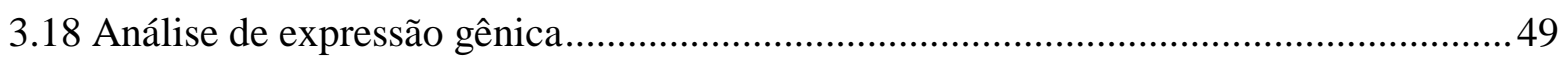

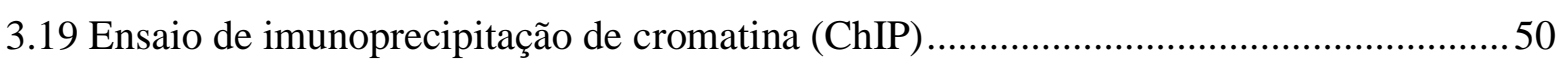

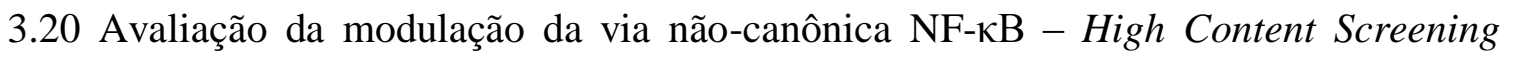

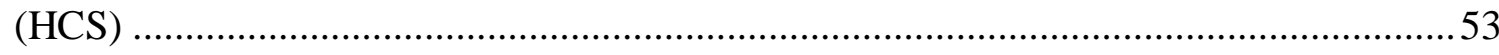


4.1 Eficiência do protocolo de marcação com anticorpos anti-TLR .56

4.2 Expressão de receptores do tipo Toll em células-tronco mesenquimais de medula óssea. .57

4.3 Análises de pureza da população de linfócitos 58

4.4 Padronização do período de co-cultivo para o ensaio de imunossupressão 59

4.5 Padronização da razão Linfócitos:CTM para o ensaio de imunossupressão . .60

4.6 A modulação da imunosupressão exercida por agonistas de receptores do tipo Toll.....62

4.7 Alterações na proliferação celular - High Content Screening (HCS) . .64

4.8 Alterações na proliferação celular - Síntese de DNA .65

4.9 Modulações da expressão gênica . .66

4.10 Modulações da atividade das vias canônica e não-canônica NF-אB - ChIP .67

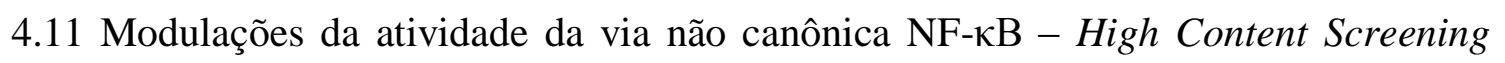
(HCS) 


\section{LISTA DE TABELAS}

Tabela1. Sondas específicas a citocinas inflamatórias, provenientes da applied

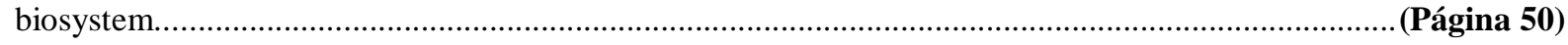

Tabela2. Níveis de expressão proteica (FL2-H Subset) de receptores do tipo Toll em monócitos isolados de PBMC..

(Página 57) 


\section{LISTA DE ILUSTRAÇÕES}

Figura 1. Representação das principais fontes de obtenção das células-tronco mesenquimais e seu potencial de diferenciação em linhagens mesodérmicas (Mesodermal differentiation) e não mesodérmicas (transdifferentiation) (extraído de Zhang et al, 2012).

(Página 21)

Figura 2. Esquema representativo da imunorregulação exercida por CTM em diversas células do sistema imune, bem como os possíveis mecanismos moleculares elucidados até o momento (extraído de Bassi et al, 2011).

(Página 22)

Figura 3. Representação da localização dos receptores do tipo Toll em membranas celulares e seus respectivos agonistas (extraído de Takeda e Akira, 2005).

(Página 26)

Figura 4. Ilustração acerca das vias de sinalização desencadeadas pela estimulação de receptores do tipo Toll, com destaque para vias dependente de MyD88 e dependente de TRIF (extraído de Kaisho e Akira, 2005).

(Página 27)

Figura 5. Ilustração acerca do mecanismo de ativação das vias canônica e não-canônica NF-кB, com destaque para os eventos de degradação do repressor $\mathrm{IkB}$ (via canônica), ou processamento do repressor dímero p100/ReLB (via não-canônica) e posterior translocação nuclear (Extraído de Gilmore, 2006).

..(Página 29)

Figura 6. Fluxograma ilustrado do ensaio de imunossupressão, destacando as etapas de separação imunomagnética (1), marcação e ativação dos linfócitos (2), cultivo de linfócitos marcados com CFSE (CN), marcados com CFSE e ativados (CP) ou co-cultivados com CTM (CTM) (3) e avaliação da proliferação celular em linfócitos isolados a partir da estratégia de gate, a partir da citometria de fluxo (4).

(Página 39)

Figura 7. Ilustração acerca da perda de intensidade de fluorescência do corante intracelular CFSE, a partir do momento de adição do corante (T1) e divisões celulares subsequentes (T2; T3; T4).

(Página 42)

Figura 8. Ilustração acerca do processo in vivo e in vitro de ativação dos linfócitos T, sendo o último realizado a partir do kit comercial: $\mathrm{T}$ cell activation/expansion kit, human (Miltenyi Biotec). Extraído de http://www.ebioscience.com/...

(Página 43)

Figura 9. Ilustração acerca das intensidades de fluorescência do corante CFSE, mensuradas após ensaios de imunossupressão, em linfócitos não ativados $(\mathrm{CN})$, ativados e cultivados isoladamente $(\mathrm{CP})$ e co-cultivados com as CTM (CTM)

(Página 45)

Figura 10. Ilustração geral do ensaio de imunoprecipitação de cromatina (ChIP), destacando as etapas de crosslink, sonicação, imunoprecipitação, purificação do DNA e qPCR. Modificado de: http://www.millipore.com/

(Página 51)

Figura11. Imagens representativas dos resultados dos níveis de expressão proteicos (PE subset) dos receptores do tipo Toll (linha azul): TLR2, TLR3, TLR4 e TLR9, em relação ao isotipo controle (linha vermelha), em monócitos derivados de PBMC, bem como o isolamento por estratégia de gate após as marcações extracelular e intracelular.

(Página 56)

Figura12. Imagens representativas dos resultados dos níveis de expressão proteicos (PE subset) dos receptores do tipo Toll (linha azul): TLR2, TLR3, TLR4 e TLR9, em relação ao isotipo controle (linha vermelha), em CTM derivadas de medula óssea.

(Página 58)

Figura13. Gráfico representando os níveis de expressão proteica (PE subset) dos receptores do tipo Toll: TLR2, TLR3, TLR4 e TLR9, observados em monócitos e CTM derivadas de medula óssea. *diferença estatisticamente significativa $(\mathrm{p}<0.05)$.

(Página 58) 
Figura14. Imagens representativas acerca das análises de pureza dos linfócitos T CD3+, isolados por separação imunomagnética, com destaque para o quadrante estabelecido através de amostras marcadas com isotipo controle (controle) a porcentagem de células $\mathrm{T}$ CD3+ marcadas com anticorpos anti-CD3 FITC (anti-CD3 FITC)

(página 59)

Figura 15. Padronização do período de co-cultivo durante o ensaio de imunossupressão. Gráficos acerca da avaliação da proliferação do controle positivo (linfócitos) ou linfócitos co-cultivados com CTM (CTM), após 3 ou 5 dias (A). Imagem representativa sobre a estratégia de gate para isolamento dos linfócitos a serem analisados quanto a proliferação celular (B). Imagens representativas acerca da perda de intensidade de fluorescência do corante CFSE, no controle positivo (linfócitos) ou linfócitos co-cultivado com CTM (CTM) após 3 dias (C) e 5 $\operatorname{dias}(\mathrm{D})$.

(página 60)

Figura 16. Padronização da razão linfócitos:CTM para o ensaio de imunossupressão. Comparações acerca da proliferação do controle positivo (controle) e linfócitos co-cultivados com CTM (CTM) em razões de 5:1, 10:1 e 20:1 (A). Comparação entre a proliferação dos linfócitos co-cultivados com CTM a razões de 5:1, 10:1 e 20:1 (B). *diferença estatisticamente significativa $(\mathrm{p}<0.05)$

(Página 62)

Figura 17. Gráfico acerca da triagem em triplicata experimental comparando a proliferação do controle positivo (Linfócitos) e de linfócitos co-cultivados com CTM não tratadas (CTM), ou estimuladas com LPS (CTM + LPS), POLY IC (CTM + POLY IC), CpG-A (CTM + CpG-A), CPG-B (CTM + CpG-B) ou DSP30 (CTM + DSP30). *diferença estatisticamente significativa $(\mathrm{p}<0.05)$.

(Página 63)

Figura 18. Gráfico representando o ensaio de imunossupressão em triplicata biológica, comparando a proliferação observada no controle positivo (Linfócitos) e linfócitos co-cultivados com CTM não tratadas (CTM) ou estimuladas com LPS (CTM + LPS), DSP30 (CTM + DSP30) ou com LPS e DSP30 simultaneamente (CTM + LPS + DSP30). *diferença estatisticamente significativa $(\mathrm{p}<0.05)$

(Página 64)

Figura 19. Alterações na proliferação celular em virtude do estímulo com agonistas de TLR. Gráfico representando o significativo da quantidade das CTM tratadas com DSP30, em relação a células não tratadas (CTM) (A). Imagens representativas acerca do aumento na quantidade de células em virtude do tratamento com DSP30 (B). *diferença estatisticamente significativa $(\mathrm{p}<0.05)$

(Página 65)

Figura 20 Alterações na síntese de DNA em virtude do estímulo com ligantes de TLR. Gráfico acerca do aumento significativo da quantidade de DNA sintetizado em virtude do estímulo com DSP30 (CTM + DSP30) em relação a CTM não estimuladas $(\mathrm{CTM}) . *$ diferença estatisticamente significativa $(\mathrm{p}<0.05)$.

(Página 66)

Figura 21. Gráficos representando alterações dos níveis de expressão gênica (Fold Change) de IL-1b e TGF $\beta$ entre as condições experimentais: CTM não estimuladas (CTM), estimuladas com LPS (CTM + LPS), DSP30 $(\mathrm{CTM}+\mathrm{DSP} 30)$ ou LPS e DSP30 simultaneamente (CTM + LPS + DSP30). *diferença estatisticamente significativa $(\mathrm{p}<0.05)$.

(Página 67)

Figura 22. Modulações por agonistas de TLR, na magnitude da força de ligação dos fatores de transcrição das

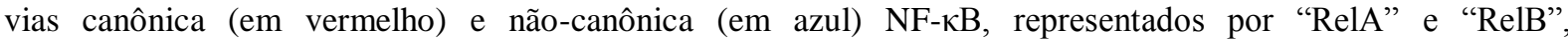
respectivamente.

(Página 68)

Figura 23. Gráfico acerca de intensidades médias de fluorescência no citoplasma, correspondente a proteína RelB, em CTM não estimuladas (CTM) ou estimuladas com LPS (CTM + LPS), DSP30 (CTM + DSP30) e ambos os ligantes simultaneamente (CTM + LPS + DSP30) (A). Imagens representativas acerca da intensidade de fluorescência observada em CTM não estimuladas (CTM) ou estimuladas simultaneamente com LPS e DSP30 $($ CTM + LPS + DSP30) $(\mathrm{B})$. *diferença estatisticamente significativa $(\mathrm{p}<0.05)$

(Página 69)

Figura 24. Ilustração acerca da polarização de fenótipos acentuadamente imunossupressor ou pró-inflamatório em virtude da estimulação com os agonistas de TLR DSP30 e LPS, respectivamente. Em destaque, está a expressão de TGF $\beta$ após estimulação por DSP30 e seu efeito em induzir a proliferação das CTM e reduzir a ativação de células T CD4+ E T CD8+. Adicionalmente, foi destacada a expressão de IL-1 $\beta$ após estimulação por LPS e seu efeito em propiciar a diferenciação de células Th17 e T CD8+....

(Página 84) 


\section{LISTA DE ABREVIATURAS E SIGLAS}

- $\mu g=$ micrograma

- $\mu \mathrm{L}=$ microlitro

- $\mu \mathrm{M}=$ micromolar

- $\mathrm{CD}=$ do inglês "Cluster of Differentiation"

- $\quad \mathrm{cDNA}=$ do inglês "Complementary Desoxiribonucleic Acid"

- DCs = do inglês "Dendritic Cells"

- $\quad \mathrm{DNA}=$ do inglês "Desoxirribonucleic Acid"

- $\quad$ DMSO = Dimetilsulfóxido

- $\quad \mathrm{FGF}=$ do inglês "Fibroblast Growth Factor"

- $\quad$ FITC $=$ do inglês "Fluorescein isothiocyanate"

- $\mathrm{FSC}=$ do inglês "Forward Scatter"

- $\mathrm{G}-\mathrm{CSF}=$ do inglês "Granulocyte colony-stimulating factor"

- $\mathrm{GVHD}=$ do inglês "Graft Versus Host Disease"

- $\mathrm{HGF}=$ do inglês: "Hepatocyte growth fator"

- $\mathrm{HLA}=$ do inglês "Human Leukocyte Antigen"

- $\quad \mathrm{ICAM}=$ do inglês "Intracellular adhesion molecule"

- $\quad$ IDO = Indoleamina 2,3-dioxigenase

- IFN-y = Interferon gamma

- $\operatorname{IgG}=$ Imunoglobulina Gama

- $\quad \mathrm{IL}=$ do inglês "Interleukin"

- $\mathrm{M}-\mathrm{CSF}=$ do inglês "Macrophage colony-stimulating factor"

- $\mathrm{MHC} 1=$ do inglês "major histocompatibility complex-1"

- $\mathrm{MHC} 2=$ do inglês "major histocompatibility complex-2"

- $\mathrm{MyD} 88$ = do inglês "myeloid differentiation primary response 88"

- $\mathrm{NF}-\kappa \mathrm{B}=$ do inglês "Nuclear Factor kappa B"

- $\mathrm{ng}=$ nanograma

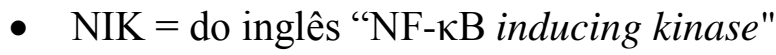

- $\mathrm{NK}=$ do inglês "Natural Killer"

- $\mathrm{nM}=$ nanomolar

- $\quad \mathrm{PBMC}=$ do inglês "Peripheral Blood Mononuclear Cells"

- $\mathrm{PBS}=$ do inglês "Phosphate Buffered Saline" 
- $\quad \mathrm{PCR}=$ do inglês "Polymerase Chain Reaction"

- $\mathrm{PE}=$ do inglês "Phycoeritrin"

- PGE2 = do inglês "Prostaglandin 2"

- $\quad$ POLY IC = do inglês "Polyinosinic:polycytidylic acid"

- $\quad \mathrm{qPCR}=$ do inglês "Quantitative Polymerase Chain Reaction"

- $\quad$ RNA = do inglês "Ribonucleic Acid"

- $\quad \mathrm{rpm}=$ rotações por minuto

- $\mathrm{SBF}=$ Soro Bovino Fetal

- $\quad \mathrm{SSC}=$ do inglês "Side Scatter"

- $\quad \mathrm{TCR}=$ do inglês " $T$ cell receptor"

- TGF- $\beta$ : Do inglês "Transforming Growth Factor beta"

- $\quad \mathrm{TLR}=$ do inglês "Toll-like receptors"

- $\quad \mathrm{TNF}=$ do inglês "Tumor Necrosis Factor"

- $\quad$ TRIF $=$ do inglês "TIR-domain-containing adapter-inducing interferon- $\beta$ "

- $\quad \mathrm{VCAM}=$ do inglês "Vascular adhesion molecule"

- VCAM1 = do inglês "Vascular cell adhesion protein 1" 


\subsection{Células-tronco mesenquimais}

Diferentemente de outros tipos celulares, as células-tronco caracterizam-se por apresentar o potencial de auto renovação, ao originar células com as mesmas propriedades das progenitoras, e também de originar células pertencentes a diferentes linhagens celulares (Ramalho-Santos et al., 2002). De acordo com a fonte de obtenção, as células-tronco podem ser classificadas em embrionárias (CTE) ou adultas (CTA), sendo as primeiras encontradas na massa celular interna do blastocisto (Bongso e Tan, 2005), enquanto as segundas em órgãos e tecidos adultos (Martinez-Agosto et al., 2007; Uccelli et al., 2008; Chong et al., 2011; Kajstura et al., 2011; Snippert e Clevers, 2011). Esta diferença no período de surgimento, durante o desenvolvimento do organismo, também é refletida no potencial de diferenciação, tendo em vista que enquanto as CTE são capazes de se diferenciar em virtualmente todas as células do organismo, as CTA apresentam o potencial de diferenciação restrito a uma ou mais linhagem celulares (Bongso e Tan, 2005; Martinez-Agosto et al., 2007; Uccelli et al., 2008).

Dentre as células-tronco adultas, até o momento se encontram mais estudadas e caracterizadas as células-tronco hematopoiéticas $(\mathrm{CTH})$ e as células-tronco mesenquimais (CTM). As células-tronco hematopoiéticas podem ser identificadas pelo fenótipo "CD34+", do qual é apresentado por cerca de $0,5 \%$ a $5 \%$ do total de células sanguíneas na medula óssea, fígado fetal e cordão umbilical, sendo capazes de se diferenciarem nas linhagens mielóide e linfóide do tecido sanguíneo (Civin et al., 1984; Digiusto et al., 1994; Krause et al., 1996). Este grupo de células apresenta a sua aplicação estabelecida na área da terapia celular, tendo em vista seu uso na reconstituição do tecido sanguíneo, necessário no tratamento de leucemias, linfomas e doenças autoimunes (Passweg et al., 2012). Uma vez no microambiente da medula óssea, as CTH compõem o estroma medular, qual também integram as célulastronco mesenquimais (CTM) (Deans e Moseley, 2000). 
O termo "células-tronco mesenquimais" (CTM) foi primeiramente cunhado por Caplan (Caplan, 1991), ao observar a capacidade in vitro e in vivo de diferenciação osteogênica e condrogênica de um grupo de células aderentes derivadas da medula óssea, postulando então a capacidade destas células de se diferenciarem em diversas outras originárias do mesênquima. Corroborando esta definição, diversos estudos foram bem sucedidos em isolar CTM de tecidos adultos derivados do mesênquima, tais como musculatura esquelética, tecido adiposo, sangue periférico e sangue de cordão umbilical (Stewart e Stewart, 2011). Devido a pluralidade de fontes de obtenção, a sociedade internacional de terapia celular (ISCT) estabeleceu diretrizes para a classificação das célulastronco mesenquimais, quais além da aderência ao plástico e capacidade de diferenciação condrogênica e osteogênica in vitro, estas células necessitam também apresentar os antígenos de superfície: CD73, CD90 e CD105, não apresentando: CD11b, CD45, CD14, CD31, CD34, CD79a e HLA DR (Dominici et al., 2006). Além destas características, foi demonstrado por Covas e colaboradores que as CTM derivadas de medula óssea e cordão umbilical apresentam níveis similares de diversos antígenos de superfície, tais como a positividade para CD29, CD13, CD49e, CD54 e negatividade para CD14, CD51/61, CD106 e CD49d (Covas et al., 2003).

Apesar do compartilhamento das características estabelecidas pela ISCT ou observadas por estudos independentes, ao comparar células-tronco mesenquimais derivadas de medula óssea e tecido adiposo, De Ugarte e colaboradores observaram que as células derivadas de medula óssea apresentam maior atividade proliferativa, além de diferenças na expressão de antígenos de superfície, tendo em vista que somente em CTM derivadas de medula óssea foi observada a presença de CD106, enquanto o CD49d foi observado somente em CTM derivadas de tecido adiposo (De Ugarte et al., 2003). Adicionalmente, através de um estudo de expressão gênica serial (SAGE), foi demonstrado por Panepucci e colaboradores 
que as CTM derivadas de medula óssea e cordão umbilical apresentam uma maior magnitude de expressão gênica relacionada a osteogênese e angiogênese, respectivamente (Panepucci et al., 2004). Estas diferenças fenotípicas fornecem indícios de que as CTM constituem um grupo heterogêneo de células, o que deve ser considerado quanto a suas aplicações na terapia celular.

Os estudos iniciais acerca da terapia celular com CTM foram direcionados a sua aplicação na medicina regenerativa, de forma a avaliar a capacidade de diferenciação destas células, objetivando sua aplicação futura na regeneração de órgãos.

A princípio, tais estudos se limitaram a avaliar o potencial de diferenciação das CTM em linhagens celulares oriundas do mesênquima, sendo demonstrada a geração in vitro de mioblastos (Jackson et al., 2010; Wakitani et al., 1995) e cardiomiócitos (Jackson et al., 2010; Planat-Benard et al., 2004; Martin-Rendon et al., 2008) funcionais, a partir de CTM humanas expandidas em cultura. Entretanto, apesar do estudo de Ferrari e colaboradores ter observado uma regeneração significativamente maior de células musculares em modelos murinos transplantados com células aderentes derivadas de medula óssea (Ferrari et al., 1998), até o momento não há evidências na literatura acerca da geração in vivo de células musculares a partir de CTM. Portanto, ainda existem dúvidas acerca da regeneração obtida após a infusão de CTM serem resultado da diferenciação direta das CTM (Orlic et al., 2001), ou somente de uma ação protetora, através da fusão celular ou secreção de fatores indutores de reprogramação celular ou regeneração (Alvarez-Dolado et al., 2003; Acquistapace et al., 2011; Kouris et al., 2012).

Mais recentemente, diversos estudos foram realizados no sentido de avaliar o potencial das CTM quanto a sua capacidade de diferenciação em múltiplas linhagens, tais como células derivadas da endoderme e ectoderme, um fenômeno denominado "transdiferenciação" (figura1). Através tanto de análises morfológicas, quanto da expressão 
de proteínas específicas, estudos demonstraram a geração de células similares a neurônios in vitro, a partir de protocolos específicos, aplicados tanto a CTM de medula óssea quanto de tecido adiposo (Pacary et al., 2006; Hayashi et al., 2013). Do mesmo modo, estudos in vitro foram bem sucedidos em diferenciar as CTM em células similares a hepatócitos, através da estimulação destas células com diversos hormônios e citocinas, incluindo HGF e FGF, fatores relacionados ao comprometimento endodermal durante o desenvolvimento embrionário (Snykers et al., 2009). De um modo geral, os estudos acerca da plasticidade fenotípica das CTM indicam que estas células podem adquirir um fenótipo similar ao encontrado por células das linhagens endodérmica e ectodérmica, quando estimuladas apropriadamente in vitro, carecendo ainda de observações controladas acerca do seu potencial de diferenciação in vivo.

Além do potencial de diferenciação das CTM, diversos estudos foram realizados sobre a sua participação durante o desenvolvimento das CTH no estroma medular. Tais estudos observaram a expressão de diversos fatores solúveis, tais como CXCL12, G-CSF, M-CSF, e SCF (Han et al., 2007; Sugiyama et al., 2006; Bernstein et al., 1991), bem como proteínas de superfície que promovem o contato celular, tais como ICAM e VCAM (Deans e Moseley, 2000; Li e Wu, 2011), que em conjunto estão relacionados a preservação de diversos aspectos das CTH, tais como proliferação, auto renovação e diferenciação (Li e Wu, 2011; Carrancio et al., 2011). De modo geral, estas observações indicam a necessidade das CTM no estroma medular para a manutenção e desenvolvimento das $\mathrm{CTH}$, além de fornecer indícios de possíveis interações também com células do sistema imune. 


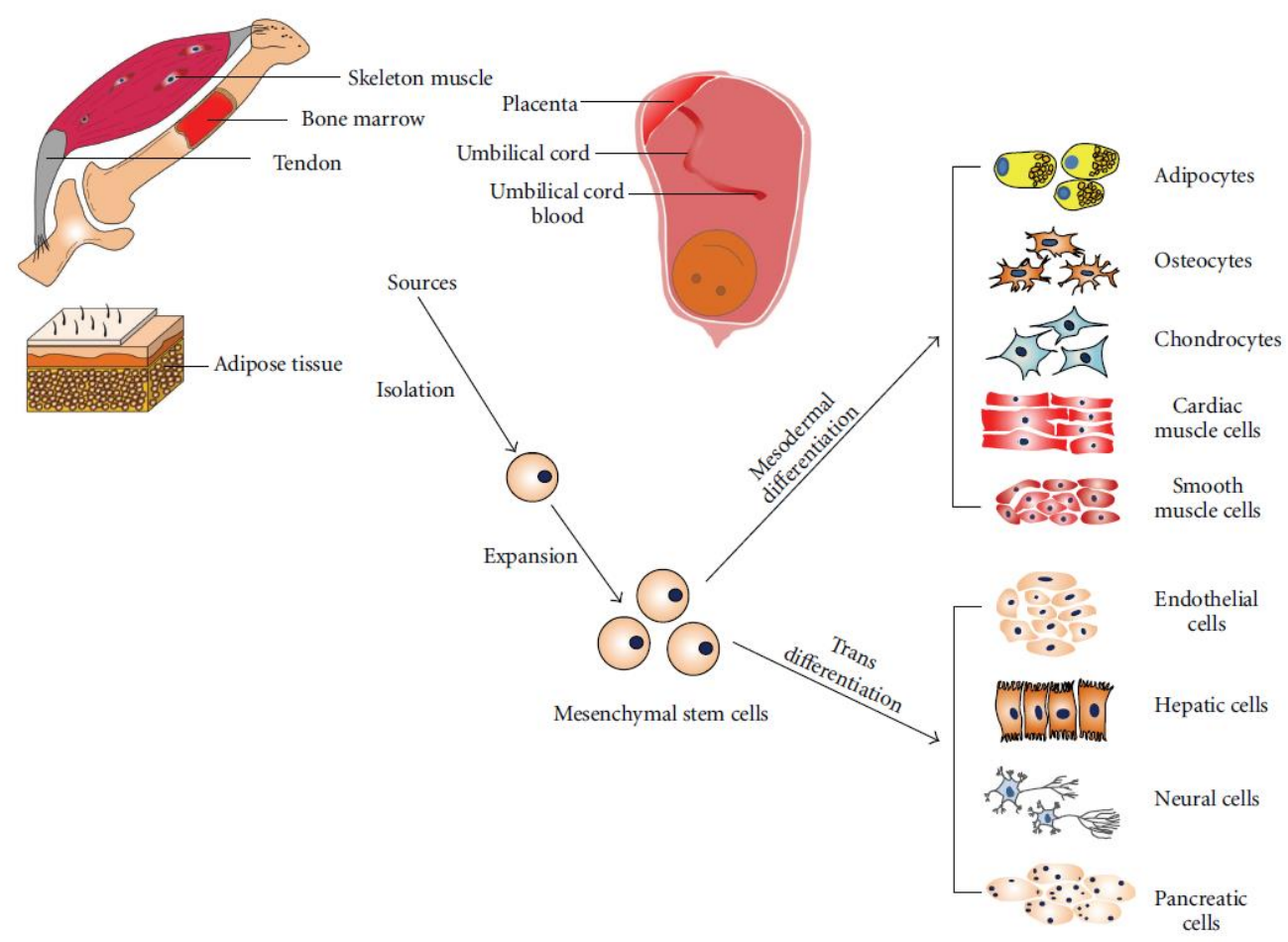

Figura 1. Representação das principais fontes de obtenção das células-tronco mesenquimais e seu potencial de diferenciação em linhagens mesodérmicas (Mesodermal differentiation) e não mesodérmicas (transdifferentiation) (extraído de Zhang et al, 2012).

\subsection{Imunorregulação mediada por células-tronco mesenquimais}

Possivelmente devido ao fato das células-tronco mesenquimais terem sido encontradas primeiramente na medula óssea, um órgão que origina e abriga células imaturas do sistema imune (Zhao et al., 2012), diversos estudos foram realizados no intuito de avaliar as contribuições destas células no desenvolvimento de linfócitos. Nesse sentido, Barda-Saad e colaboradores observaram que as células do timo, um órgão onde ocorre a maturação de linfócitos T imaturos (ou “naive”) (Germain, 2002), são capazes de aderir em células-tronco mesenquimais in vitro (Barda-Saad et al., 1997; Barda-Saad et al., 1999). Adicionalmente, Li e colaboradores observaram que após realizado o transplante de CTH (TCTH) em camundongos, as células-tronco mesenquimais são capazes de migrar para o timo, sendo sua presença neste órgão relacionada a uma quantidade significativamente maior de células maduras T CD4+ e CD8+ (Li et al., 2000). 
Analisando uma possível atividade imunorregulatória inerente as CTM, Di nicola e colaboradores observaram a síntese constitutiva da citocina anti-inflamatória TGF- $\beta$, bem como a inibição da proliferação de células T ativadas, co-cultivadas com as CTM (Di Nicola, 2002). Posteriormente, este efeito imunossupressor também foi observado em células dendríticas (DCs), pois a presença das CTM foi capaz de inibir sua maturação, o que foi confirmado pela incapacidade destas células em induzir respostas inflamatórias em células T (Zhang et al., 2004). Corroborando que o efeito imunossupressor das CTM se estende para células do sistema imune inato, Németh e colaboradores observaram que a infusão de CTM em camundongos induzidos a sepse resultou na geração de macrófagos secretores de IL-10, uma citocina anti-inflamatória (Nemeth et al., 2009). Atualmente, o potencial imunorregulatório das CTM se encontra amplamente corroborado in vitro, sendo conhecida a participação de mecanismos de contato celular e secreção de fatores solúveis, tais como HGF, TGF- $\beta$, PGE2 e IDO (Yagi et al., 2010; Bassi et al., 2011; Soleymaninejadian et al., 2012), atuando em diversas células do sistema imune (Figura 2).

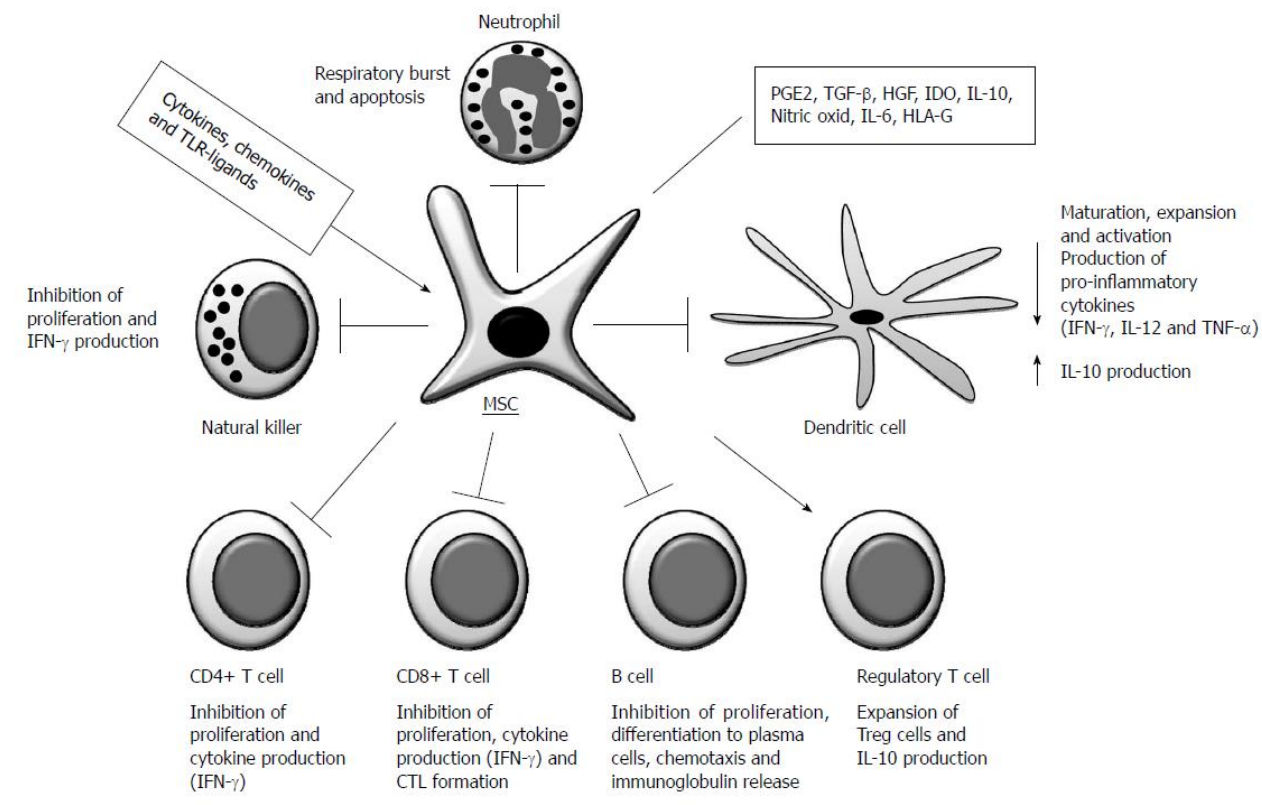

Figura 2. Esquema representativo da imunorregulação exercida por CTM em diversas células do sistema imune, bem como os possíveis mecanismos moleculares elucidados até o momento (extraído de Bassi et al, 2011) 
Além da privação do aminoácido Triptofano, através do seu catabolismo induzido pela ação do IDO (Mellor e Munn, 1999), a supressão da proliferação das células T pode decorrer de diferentes vias metabólicas, ativadas após sua interação com os fatores secretados pelas CTM. Mais recentemente, Saldanha-Araújo e colaboradores demonstraram que este efeito imunossupressor decorre, ao menos em parte, de uma indução a ativação da via não-canônica NF-кB em linfócitos, como observado pela inibição da atividade imunossupressora ao ser silenciada a expressão de RelB, uma proteína mediadora desta mesma via(Saldanha-Araujo et al., 2012). Posteriormente, foi observado pelo mesmo grupo que durante o co-cultivo entre CTM e linfócitos T ativados, ocorreu um aumento da expressão de CD39 e CD73, respectivamente, o que esteve relacionado a secreção de adenosina pelas CTM e redução na proliferação dos linfócitos (Saldanha-Araujo et al., 2011). Tal observação indica que a secreção da adenosina através das CTM possivelmente atua como um mecanismo imunossupressor adicional, de atuação nos receptores CD73 presente em linfócitos e consequentemente levando ao aumento dos níveis intracelulares de cAMP, um agente imunossupressor (Ruppelt et al., 2007; Ramstad et al., 2000).

Além da atividade imunossupressora, estudos anteriores observaram que as CTM apresentam um fenótipo imunoprivilegiado, devido a expressão de baixos níveis das proteínas de membrana MHC1 e MHC2, utilizadas pelos linfócitos para o reconhecimento como células do próprio corpo (self) ou células estranhas (non-self), bem como baixos níveis de moléculas co-estimulatórias de linfócitos, a exemplo de CD40, CD80 e CD86 (Bassi et al., 2011; Franquesa et al., 2012).

Em conjunto, tanto a atividade imunossupressora quanto o fenótipo imunoprivilegiado das CTM obtiveram atenção da comunidade científica, tendo em vista sua aplicação em imunoterapias objetivando reverter o estado alterado de ativação em células do sistema imune, em especial os linfócitos T CD4+ e T CD8+. Tal fenômeno está associado a diversas 
enfermidades, tais como doenças autoimunes (Uccelli et al., 2013; Papadopoulou et al., 2012; Connick et al., 2012; Ciccocioppo et al., 2011; Carrion e Figueroa, 2011; Mao et al., 2010; Duijvestein et al., 2010; Zhou et al., 2008; Chen e Tuan, 2008) e a Doença do Encherto Contra o Hospedeiro (DECH) (Tolar et al., 2011; Le Blanc et al., 2004), quais respostas inflamatórias desencadeadas por células do sistema imune são direcionadas a células do próprio organismo. Diferentemente das outras enfermidades, a DECH se desenvolve em pacientes sujeitos ao TCTH, sendo desencadeada devido a incompatibilidade imunológica entre as células apresentadoras de antígenos (APC) do hospedeiro e as células $\mathrm{T}$ do doador (Weisdorf, 2007; Jacobsohn e Vogelsang, 2007).

De um modo geral, os estudos clínicos realizados até o momento demonstraram a segurança e eficácia da terapia celular com CTM, em termos do aprimoramento do quadro clínico ou mesmo remissão completa, de pacientes com Lúpus Sistêmico Eritematoso (Sun et al., 2009), Doença de Crohn (Garcia-Olmo et al., 2009), Esclerose Múltipla (Connick et al., 2012) e DECH (Le Blanc et al., 2004; Le Blanc et al., 2008). Neste último caso, estudos multicêntricos realizados em larga escala observaram também a ineficácia da terapia com CTM (Lazarus et al., 2005; Caimi et al., 2010; Kim et al., 2013), indo de encontro com resultados de outros estudos e também com o esperado, a partir de observações in vitro, acerca do potencial imunossupressor das CTM.

Estas diferenças encontradas em estudos clínicos podem refletir não somente a variação em métodos de isolamento, expansão e período de infusão das CTM, mas também a presença de infecções por diferentes vírus, bactérias e fungos comumente associadas a DECH (Jacobsohn e Vogelsang, 2007; Deeg, 2007; Goerner et al., 2002). Tal situação possibilita que fragmentos de patógenos, circulantes na corrente sanguínea, possam interagir com as CTM após a infusão, através de receptores do tipo Toll, modulando sua atividade imunossupressora e resultando na variabilidade observada nos resultados de estudos clínicos. 


\subsection{A imunomodulação excercida por receptores do tipo Toll}

Para que as células do sistema imune inato sejam capazes para discernir estruturas próprias do corpo (self) daquelas pertencentes aos patógenos (non-self), elas apresentam receptores específicos tais como os receptores do tipo Toll (TLR) (Aderem e Ulevitch, 2000). Em seres humanos, os TLR são um grupo de 10 proteínas (TLR1 - TLR10) transmembranares com um domínio C-terminal intracelular e um N-terminal extracelular, cuja função é o reconhecimento de Padrões Moleculares Associados a Patógeno (PAMPs): estruturas presentes em bactérias, protozoários, fungos e vírus (West et al., 2006). Exemplos de estruturas patogênicas reconhecidas como PAMPs por TLR são: RNA de dupla fita (dsRNA, reconhecido por TLR3) presentes em vírus de RNA, lipopeptídeo (reconhecido por TLR2) presente em bactérias gram negativas, lipopolissacarídeo bacteriano (LPS, reconhecido por TLR4) e DNA com motivos CpG não metilados (CpG-DNA, reconhecido por TLR9), presentes no DNA de diversos patógenos, tais como vírus, bactérias e protozoários (West et al., 2006).

A localização de cada receptor tipo Toll está associada ao tipo de ligante reconhecido (figura 3), visto que enquanto aqueles que reconhecem lipídios e peptídeos estão localizados na membrana plasmática, os que reconhecem nucleotídeos estão localizados em endossomos (Mcgettrick e O'neill, 2010). Este fato têm implicações biológicas importantes, pois a presença do TLR9 em endossomos impede o reconhecimento de fragmentos de DNA do self, que usualmente não adentra em compartimentos endossômicos, dificultando a ativação de células do sistema imune (Blasius e Beutler, 2010). Adicionalmente, TLR situados na membrana plasmática, responsáveis pelo reconhecimento do microambiente externo, são específicos para lipídios e peptídeos de patógenos (West et al., 2006; Mcgettrick e O'neill, 2010). 


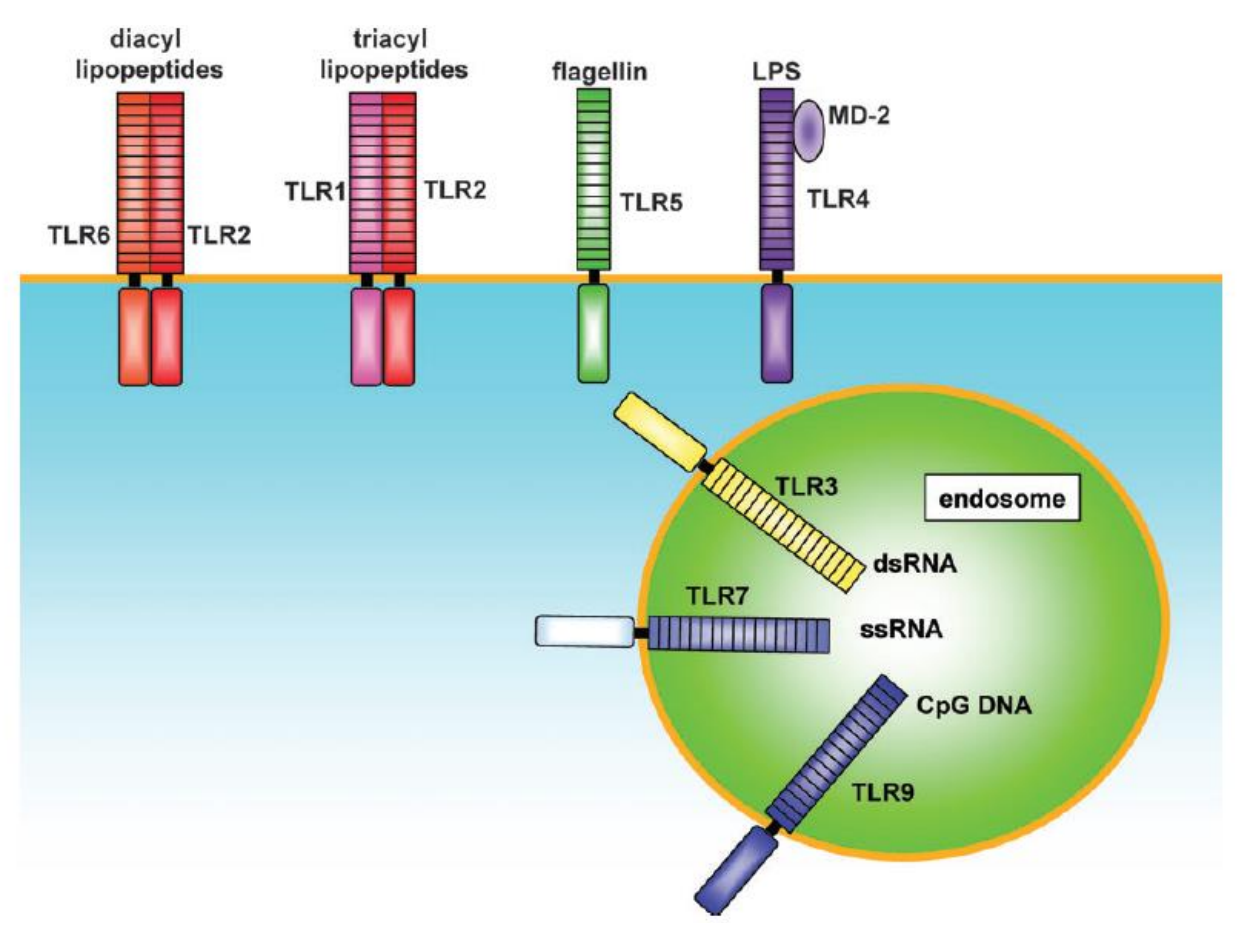

Figura 3. Representação da localização dos receptores do tipo Toll em membranas celulares e seus respectivos agonistas (extraído de Takeda e Akira, 2005).

Estudos acerca das funções dos TLR, realizados em células apresentadoras de antígenos, demonstraram que a estimulação destes receptores têm como resultado a indução da expressão de moléculas co-estimulatórias de linfócitos e secreção de citocinas inflamatórias, sendo crucial para o recrutamento e ativação de linfócitos no combate a infecção por patógenos (Takeda e Akira, 2005). Embora os mecanismos inerentes a esta resposta não estejam completamente esclarecidos, atualmente é sabido que de um modo geral, os receptores do tipo Toll podem ativar duas cascatas de sinalização distintas: a dependente de MyD88 e a dependente de TRIF (figura 4) (Kaisho e Akira, 2005). Resumidamente, tanto a sinalização dependente MyD88 quanto a dependente de TRIF resultam no recrutamento de cinases e fosforilação de proteínas, que em última instância levam a ativação do fator de transcrição dia via canônica NF- $\kappa \mathrm{B}$ e consequente síntese de citocinas inflamatórias, entretanto, a via dependente de TRIF resulta também na ativação do fator de regulação 3 de interferon (IRF3), resultando na expressão de IFN $\beta$ (Uematsu e Akira, 2007). 


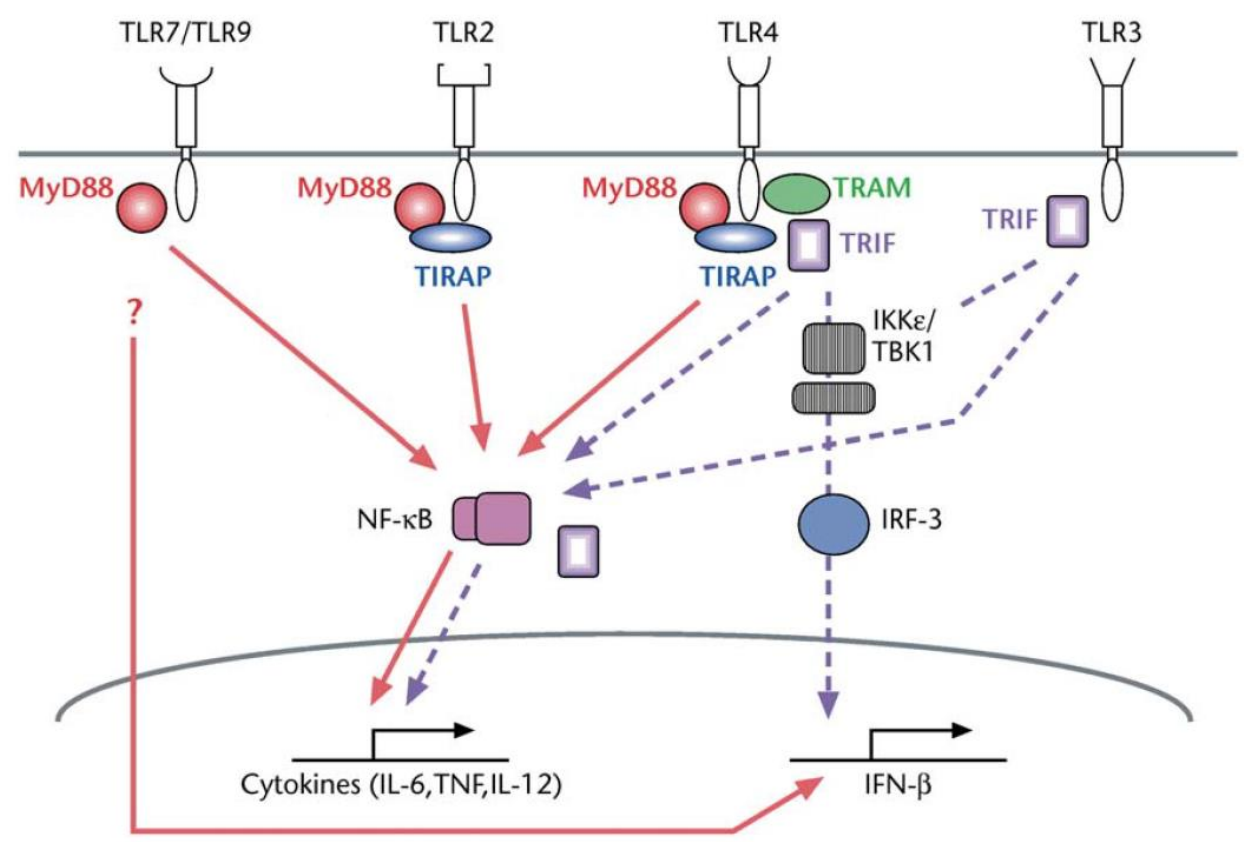

Figura 4. Ilustração acerca das vias de sinalização desencadeadas pela estimulação de receptores do tipo Toll, com destaque para vias dependente de MyD88 e dependente de TRIF (extraído de Kaisho e Akira, 2005).

Apesar de estudos anteriores terem observado a ativação de vias de sinalização proinflamatórias de um modo geral, a estimulação de receptores do tipo Toll parece também resultar na ativação de vias anti-inflamatórias, sendo isto particularmente verdadeiro quanto a estimulação do TLR9. Recentemente, o grupo de Wingender e colaboradores demonstraram que a aplicação sistêmica de um constructo sintético de oligonucleotídeo com motivos CpG (CpG ODN), em modelo murino, resultou em uma maior secreção de IDO por células do baço e supressão da proliferação de linfócitos (Wingender et al., 2006). Corroborando estas observações, o grupo de Mellor e colaboradores observaram uma potente atividade imunossupressora proveniente de uma subpopulação de células dendríticas, isoladas do baço de camundongos, quando estimuladas por constructos distintos de CpG ODN (Mellor et al., 2005).

Observações acerca da ativação de vias pró e anti-inflamatórias, induzidas após a estimulação de receptores do tipo Toll, podem estar relacionados ao papel duplo exercida pelas vias $\mathrm{NF}-\kappa \mathrm{B}$. 
A via clássica (ou canônica) NF-אB é mediada por um fator de transcrição composto pelas proteínas dimerizadas p50/RelA, mantidas no citoplasma devido a sua interação com a proteína repressora I $\mathrm{B} \alpha$ (Figura 5) (Gilmore, 2006). Após a estimulação por diversos receptores celulares situados na membrana plasmática, tais como exemplo de receptores para TNF e receptores do tipo Toll, proteínas adaptadoras são recrutadas para o domínio

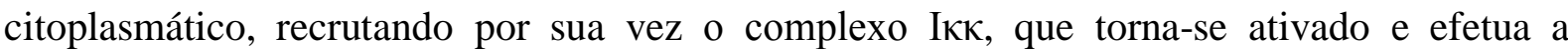
fosforilação da proteína $\mathrm{IkB} \alpha$, sendo ubiquitinada e degradada pelo proteassoma (Hayden, 2004). Este mecanismo têm como consequência a liberação do fator de transcrição da via canônica, sendo então translocado para o núcleo e ligando-se a regiões promotoras de diversos genes, tais como citocinas pro-inflamatórias, proteínas de adesão e também para sua proteína repressora, em um mecanismo de "feedback" negativo (Hayden, 2004; Oeckinghaus e Ghosh, 2009; Ghosh et al., 2012; Biswas e Lewis, 2010).

Alternativamente a via clássica, a via não-canônica NF-кB é mediada pelo fator de transcrição composto pelas proteínas dimerizadas p52/RelB, que somente é formado após a degradação do seu precursor: p100/RelB (Gilmore, 2006). Este fenômeno é induzido principalmente pela estimulação do ligante de CD40 (CD40L) em células T, resultando na ativação da cinase indutora do NF-אB (NIK), que participa da fosforilação de complexos Ikk $\alpha$, que por sua vez atuam na fosforilação da proteína p100, levando a sua degradação parcial e formando a proteína p52 (Gilmore, 2006; Sun, 2012). Uma vez formado o fator de transcrição p52/ReLB, este sofre translocação para o núcleo, atuando em regiões promotoras para genes codificadores de diversas quimiocinas, além da enzima IDO (Biswas e Lewis, 2010; Sun, 2012). 


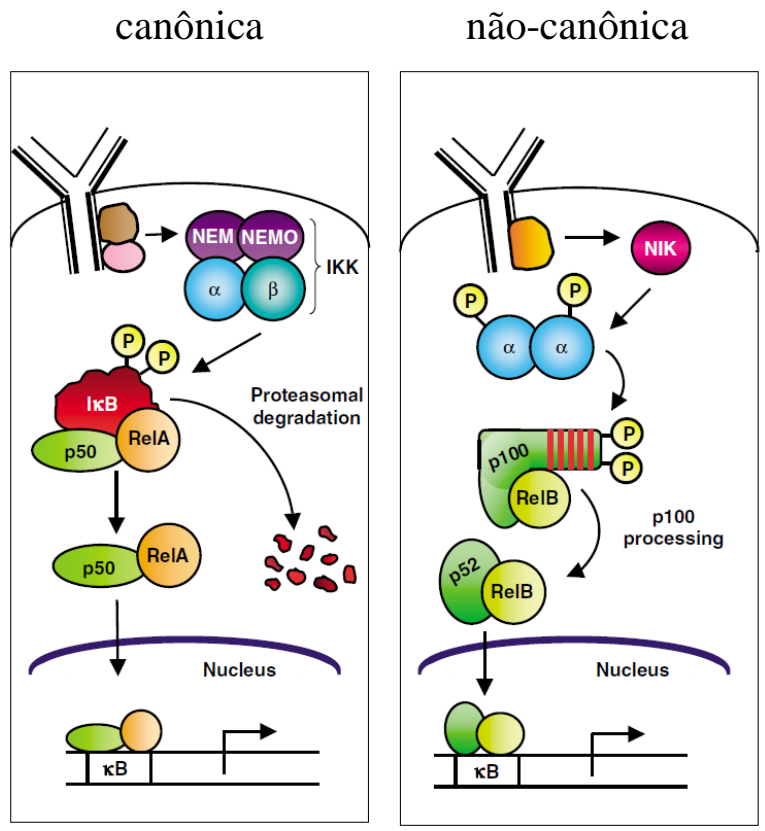

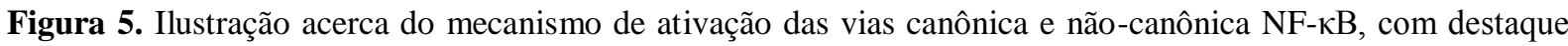
para os eventos de degradação do repressor IkB (via canônica), ou processamento do repressor dímero p100/ReLB (via não-canônica) e posterior translocação nuclear (Extraído de Gilmore, 2006).

Devido a sua capacidade de modular a atividade imunossupressora, a presença dos receptores do tipo Toll em células-tronco mesenquimais apresenta implicações importantes quanto a terapia celular, tendo em vista a frequente presença de infecções associadas em indivíduos com DECH e doenças autoimunes. Estudos anteriores observaram que a expressão dos TLR em células-tronco mesenquimais parece variar de acordo com a fonte e técnica utilizada, tendo em vista que enquanto os TLR2, TLR3 e TLR4 foram encontrados em CTM derivadas de tecido adiposo e medula óssea, através de qPCR e citometria de fluxo, a expressão do TLR9 não foi encontrada em estudos que utilizaram a técnica de qPCR, mas citometria de fluxo e western blot (Hwa Cho et al., 2006; Liotta et al., 2008; Lombardo et al., 2009).

Além de a literatura ser recente acerca da modulação do potencial imunorregulatório das CTM em virtude da estimulação com agonistas para TLR, os estudos realizados até o momento apresentam dados contraditórios acerca dos agonistas avaliados. Como exemplos, enquanto o grupo de Lombardo e colaboradores observou que o tratamento com LPS não 
alterou a imunossupressão das CTM de tecido adiposo (Lombardo et al., 2009), o grupo de Opitz e colaboradores observou que a interação das CTM de medula óssea com LPS resultou no aumento da capacidade imunossupressora, resultante de uma maior síntese de IDO, mas não TGF $\beta$ (Opitz et al., 2009). De outro modo, os grupos de Liotta e colaboradores (Liotta et al., 2008), também o de Waterman e colaboradores (Waterman et al., 2010), corroboraram que o estímulo com LPS é capaz de prejudicar a capacidade imunossupressora das CTM sem alterar o padrão de expressão de IDO e TGFß. Apesar da concordância entre os resultados observados pelos estudos de Liotta e Waterman quanto ao estímulo por LPS, estes apresentaram dados contraditórios acerca dos efeitos moduladores do POLY IC, visto que enquanto o primeiro demonstrou a redução da capacidade imunossupressora, o segundo observou um aumento na mesma, o que foi acompanhado pela maior atividade de IDO e PGE2.

De forma ainda menos esclarecida estão os efeitos da estimulação das CTM com CpGODN. Um estudo publicado por Cho e colaboradores utilizando CTM derivadas de tecido adiposo, observou que dois constructos desse ligante resultaram na redução da capacidade de diferenciação osteogênica e também na proliferação celular (Hwa Cho et al., 2006). Avaliando possíveis modulações no potencial imunossupressor, enquanto o estudo de Tomchuck e colaboradores não detectou alterações na via NF-אB e citocinas inflamatórias em CTM derivadas de medula óssea (Tomchuck et al., 2008), recentemente, o estudo de Chen e colaboradores observou que o tratamento de CTM derivadas de cordão umbilical com um constructo diferente de $\mathrm{CpG} \mathrm{ODN}$, resultou no aumento do potencial imunossupressor e síntese de IDO (Chen et al., 2013). Esta variedade de observações distintas em relação aos efeitos da estimulação do TLR9 possivelmente é devido não somente a variação na fonte das CTM utilizada nos estudos, mas também a utilização de constructos diferentes deste oligonucleotídeo sintético. 
Ao contrário de outros ligantes de TLR, os CpG ODN constituem um grupo heterogêneo de constructos sintéticos, que são agrupados em três classes distintas, de acordo tanto com sua estrutura molecular quanto seu efeito em células do sistema imune (Sivori et al., 2006). Os CpG ODN de classe A apresentam uma região palindrômica central flanqueada por regiões ricas em guanina, não apresentando efeitos em células $\mathrm{B}$, mas ativando células dendríticas (Krug et al., 2001; Krieg, 2002; Van Ojik et al., 2003). De outro modo, CpG ODN de classe B apresentam sequências hexaméricas " 5 '-GTCGTT-3", induzindo a proliferação de células B, enquanto não exercem efeitos em células dendríticas (Krieg, 2002; Van Ojik et al., 2003; Vollmer et al., 2004). Mais recentemente, um outro tipo de oligonucleotídeo foi descoberto: o CpG ODN de classe C, apresentando sequências hexaméricas a 5' e sequências palindrômicas a 3', ligadas por sequências de Timina, tendo como efeitos a indução na proliferação e ativação de células B e DCs, respectivamente (Vollmer et al., 2004).

Como um todo, existe a necessidade de maior elucidação acerca da imunomodulação desencadeada pelo estímulo de receptores do tipo-Toll em CTM, bem dos mecanismos inerentes a estes efeitos. Tendo em vista a possibilidade da estimulação das CTM com agonistas para TLR, previamente sua aplicação em imunoterapias, bem como da antecipação acerca da modulação de seu potencial imunossupressor após a infusão, em decorrência de infecções por patógenos, o conhecimento acerca do potencial imunomodulador dos TLR apresenta um potencial quanto a sua aplicação em imunoterapias. 


\subsection{Objetivo Geral:}

Avaliar imunomodulação exercida através da estimulação dos receptores do tipo Toll, em células-tronco mesenquimais de medula óssea, bem como os possíveis mecanismos moleculares envolvidos.

\subsection{Objetivos Específicos:}

- Avaliar a expressão proteica dos receptores do tipo Toll, em células-tronco mesenquimais de medula óssea.

- Padronizar o ensaio de imunossupressão.

- Avaliar a capacidade das CTM em suprimir a proliferação dos linfócitos, bem como a modulação desta capacidade, através do estímulo com agonistas de receptores do tipo Toll.

- Avaliar alterações na capacidade proliferativa das CTM, em virtude do estímulo com agonistas de receptores do tipo Toll.

- Mensurar a modulação na expressão gênica de fatores relacionados a imunossupressão, após o estímulo com agonistas de receptores do tipo Toll.

- Mensurar a modulação na atividade dos fatores de transcrição das vias canônica e não-

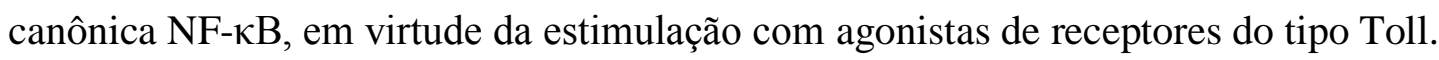




\subsection{Células-tronco mesenquimais}

As CTM a serem utilizadas neste projeto foram obtidas conforme descrito em trabalhos anteriores (Panepucci et al., 2004; Silva et al., 2003) a partir de amostras de medula óssea de doadores com consentimento, após total esclarecimento, de acordo com protocolos aprovados pelo Comitê de Ética em Pesquisa do Hospital das Clínicas da USP de Ribeirão Preto, que estão inseridos no projeto: "Isolamento e Caracterização de Células Progenitoras Mesenquimais de Diferentes Tecidos.” Processo HCRP no 4855/2004. Adicionalmente, todas as amostras de CTM utilizadas neste estudo foram previamente caracterizadas por técnicas de imunofenotipagem e colorações, sendo positivas para os marcadores CD73, CD90, CD105, CD106, CD166, CD29 e CD44 e negativas para CD45, CD14, CD31, CD34 e HLA DR, bem como capazes de se diferenciarem em adipócitos (coloração com “Sudan II"), osteócitos (coloração com “von kossa”) e condrócitos (imunocoloração com antígeno tipo II).

\subsection{Cultura celular}

Culturas de CTM foram realizadas em garrafas de cultura celular de $75 \mathrm{~cm}^{2}$, contendo 10 ml de meio de cultura composto por meio alfa-mínimo essencial (alpha-MEM, Invitrogen; Carlsbad, CA, EUA), suplementado com $50 \mathrm{U} / \mathrm{ml}$ de penicilina e $50 \mu \mathrm{g} / \mathrm{ml}$ streptomicina e $15 \%$ de SBF, sendo dispostas em uma estufa de $\mathrm{CO} 2$ a $37^{\circ} \mathrm{C}$. A cada dois dias, houve substituição de $50 \%$ do meio de cultura até que a confluência de $80 \%$ fosse atingida, havendo remoção do meio de cultura e adição de $5 \mathrm{ml}$ de solução de tripsina a $1 \mathrm{X}$ em água destilada, por 5 minutos, para que as células aderentes atingissem o estado de suspensão. Após este período, $15 \mathrm{ml}$ de meio de cultura foi adicionado e a suspensão celular foi então submetida a centrifugação a $1.500 \mathrm{rpm}$ por 10 minutos, havendo o descarte do sobrenadante e suspensão do pellet celular em meio de cultura. Após a quantificação das células a partir da contagem em câmara de Neubauer, as células foram cultivadas novamente em garrafas de cultura celular 
com meio de cultura, criopreservadas em meio de congelamento (90\% SBF e $10 \%$ DMSO) ou utilizadas em procedimentos experimentais. Em todo caso, as CTM foram utilizadas até no máximo a quinta passagem.

\subsection{Obtenção das Células Mononucleares do Sangue Periférico (PBMC)}

As células mononucleares do sangue periférico (PBMC) foram fornecidas por doadores saudáveis, no intuito de serem utilizadas em diversos ensaios, tais como padronizações de protocolos de marcação com anticorpos e isolamento de linfócitos T. Uma vez coletada amostras de sangue periférico, foi adicionado PBS em volume correspondente a três vezes o volume sanguíneo, sendo a solução sanguínea disposta na parte superior do gradiente de centrifugação Ficoll-Hypaque (GE Healthcare; Piscataway, NJ, EUA), seguido da centrifugação a $2.500 \mathrm{rpm}$ por 30 minutos para separação das frações celulares. Posteriormente, foi coletada a fração correspondente as PBMC e efetuadas três lavagens em PBS a $1.500 \mathrm{rpm}$ por 10 minutos, seguido da quantificação do número de células através da contagem em câmara de Neubauer.

\subsection{Citometria de fluxo}

Nos ensaios descritos neste projeto que necessitaram de análise por citometria de fluxo, o citômetro FACSCalibur (Becton Dickinson; San Jose, CA, EUA) foi utilizado para aquisição de células. Em todo caso, um total de 10.000 eventos foram adquiridos em células dispostas em tubos de ensaio para $3 \mathrm{ml}$ de fundo redondo (Becton Dickinson; San Jose, CA, EUA), para posterior análise no software FlowJo Vx (Tree Star, Ashland, OR, EUA). Quando necessário, populações celulares foram isoladas, através da estratégia de gate, sendo então analisadas as intensidades de fluorescência nas populações celulares de interesse. 


\subsection{Análises estatísticas}

O software Graphpad Prism 5.0 foi utilizado para todas as análises estatísticas realizadas neste trabalho. Análises paramétricas foram utilizadas para comparações entre dois ("Teste t de student”) ou mais (“One-Way ANOVA”) grupos experimentais, havendo a comparação dos grupos experimentais entre si (pós-teste de Tukey), quando necessário. Em todo caso, os resultados foram considerados estatisticamente significativos quando $\mathrm{p}<0.05$.

\subsection{Avaliação da expressão de receptores do tipo Toll a níveis proteicos}

No intuito de avaliar a eficiência tanto do protocolo de marcação quanto dos anticorpos anti-TLR, foram utilizadas PBMC derivadas de doadores saudáveis $(\mathrm{n}=3)$ com posterior isolamento de monócitos, devido as células do sistema imune inato apresentarem a expressão de todos TLR a níveis proteicos (Takeda e Akira, 2005; Kaisho e Akira, 2005). Para tanto, $2 \times 10^{5}$ PBMC foram separadas em tubos de ensaio de fundo redondo, sendo lavadas com $2 \mathrm{ml}$ de PBS a $1.500 \mathrm{rpm}$ por 10 minutos, sendo e ressuspensas e fixadas com uma solução de formol a 2\% em PBS, por 5 minutos, seguido de lavagem com PBS. Posteriormente, células sujeitas as marcações extracelular e intracelular foram ressuspensas em $100 \mu 1$ de PBS e 100 $\mu \mathrm{l}$ do reagente de permeabilização contido no kit comercial: Fix \& Perm Kit (Caltag Medsystems; Burlingame, CA, EUA), respectivamente, por 15 minutos, sendo lavadas com PBS a $1.500 \mathrm{rpm}$ por 10 minutos. Finalmente, as células foram ressuspensas em PBS e incubadas por 20 minutos com $5 \mu \mathrm{l}$ de isotipo controle: IgG1 FITC, IgG2a PE (BDBiosciences; San Diego, CA, EUA), ou $5 \mu 1$ de anticorpos específicos, conjugados a PE, contra TLR2, TLR3, TLR4 ou TLR9 (eBioscience; San Diego, CA, EUA).

Após o período de incubação, as células foram lavadas e ressuspensas em uma solução de formol a $2 \%$ em PBS, sendo analisadas por citometria de fluxo no canal FL-2, correspondente ao espectro de emissão do fluoróforo PE. Com uso do software Flow Jo VX, os monócitos 
foram isolados a partir da estratégia de gate, sendo avaliados os níveis de expressão proteica de cada TLR, a partir do intervalo de fluorescência delimitado pelo isotipo controle.

Uma vez confirmada a eficiência do protocolo de marcação com anticorpos anti-TLR, em PBMC, CTM derivadas de três doadores foram cultivadas em placas de cultura celular de 6 poços, por $24 \mathrm{~h}$. Após este período, o meio de cultura foi removido e as células foram lavadas por duas vezes em PBS, ressuspensas em PBS a $0^{\circ} \mathrm{C}$ e separadas $2 \times 10^{5}$ células por tubo de ensaio. Em seguida, as células foram marcadas com anticorpos específicos contra TLR2, TLR3, TLR4 e TLR9, utilizando-se o mesmo protocolo descrito para a marcação em PBMC. Os resultados dos níveis de expressão proteica de cada TLR, correspondentes tanto aos monócitos isolados de PBMC quanto as amostras de CTM, foram exportados para planilhas no software Microsoft Excel, sendo comparados por análises estatísticas.

\subsection{Agonistas de receptores do tipo Toll}

Para estimulação dos receptores do tipo Toll em CTM de medula óssea, no intuito de avaliar a modulação de diversas propriedades biológicas relacionadas a imunorregulação, foram utilizados agonistas específicos de determinados receptores. Portanto, foram utilizados agonistas específicos de TLR3: ácido poli-inosínico-poli-citidílicode de baixo peso molecular (POLY IC LMW, INVIVOGEN; San diego, CA, EUA), TLR4: Lipopolissacarídeo bacteriano extraído em fenol e enzimas hidrolíticas (LPS, Sigma-Aldrich; Steinhein, Alemanha) e TLR9: Oligonucleotídeo ODN 2216 (CpG-A; 1 $\mu \mathrm{g} / \mathrm{ml}$; CpG ODN-B, INVIVOGEN; San diego, CA, EUA), Oligonucleotídeo ODN 2006 (CpG-B; 1 $\mu \mathrm{g} / \mathrm{ml}$; CpG ODN-A, INVIVOGEN; San diego, CA, EUA) ou Oligonucleotídeo DSP30 (TCGTCGCTGTCTCCGCTTCTTCTTGCC, TIB-MOLBIOL; Berlin, Alemanha). 


\subsection{O ensaio de imunossupressão}

A capacidade das CTM de medula óssea em suprimir a proliferação dos linfócitos, bem como a modulação da imunossupressão por agonistas de TLR, foram avaliadas em ensaios de imunossupressão (figura 6). Resumidamente, os linfócitos $\mathrm{T}$ isolados a partir de um kit comercial foram marcados intracelularmente com o corante diacetato carboxifluoresceína succinimidyl éster (CFSE), sendo ativados ou não com partículas magnéticas acopladas e anticorpos específicos a receptores das células T. Os linfócitos marcados e não ativados foram cultivados isoladamente, enquanto outros marcados e ativados foram cultivados isoladamente ou co-cultivados com CTM, previamente tratadas ou não com os agonistas de TLR. Após um determinado período de tempo, a proliferação celular foi avaliada por citometria de fluxo, a partir da quantificação da intensidade de fluorescência do corante intracelular presente na população de linfócitos T, após seu isolamento através da estratégia de gate.

(1)

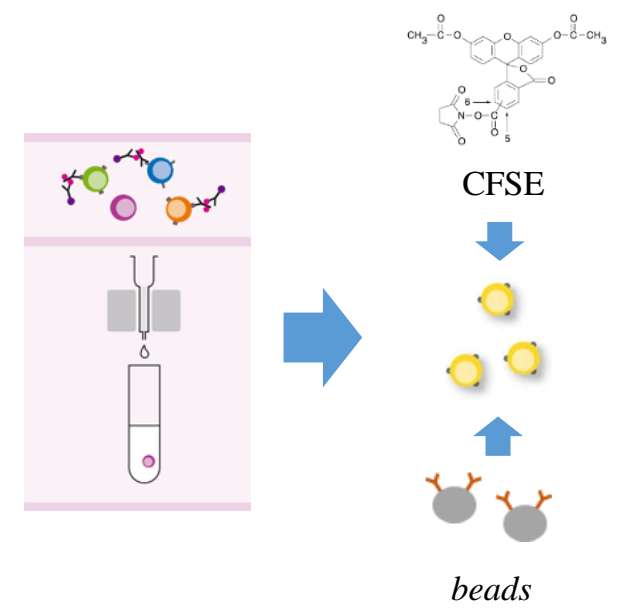

(2)

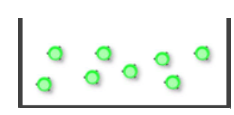

$\mathrm{CP}$
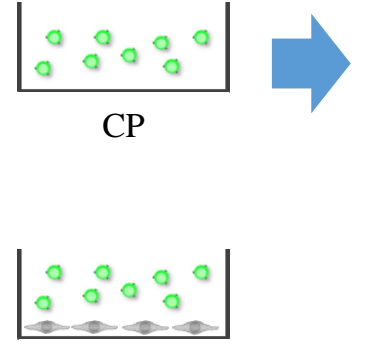

CTM
(4)
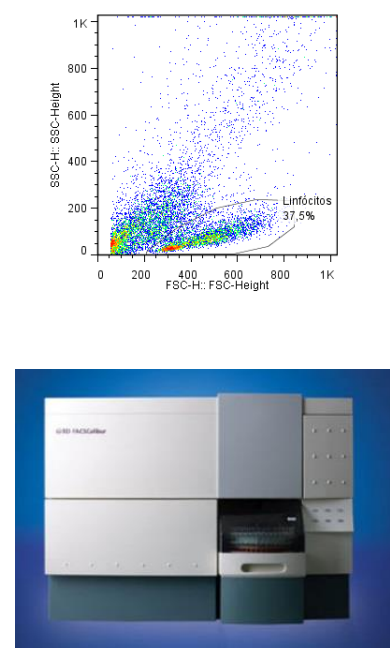

Figura 6. Fluxograma ilustrado do ensaio de imunossupressão, destacando as etapas de separação imunomagnética (1), marcação e ativação dos linfócitos (2), cultivo de linfócitos marcados com CFSE (CN), marcados com CFSE e ativados (CP) ou co-cultivados com CTM (CTM) (3) e avaliação da proliferação celular em linfócitos isolados a partir da estratégia de gate, a partir da citometria de fluxo (4). 


\subsection{Estimulação das células-tronco mesenquimais com agonistas de TLR}

Em virtude de avaliar o efeito imunomodulatório decorrente da estimulação de receptores do tipo Toll, CTM $(n=3)$ foram cultivadas em placas de cultura celular de 24 poços, a $1 \times 10^{4} /$ poço e por 24 horas. Após este período, as células foram estimuladas ou não com agonistas para TLR: LPS $(1 \mu \mathrm{g} / \mathrm{ml})$, POLY IC $(1 \mu \mathrm{g} / \mathrm{ml})$, CPG-A $(1 \mu \mathrm{g} / \mathrm{ml})$, CPG-B $(1 \mu \mathrm{g} / \mathrm{ml})$ ou DSP30 $(1 \mu \mathrm{M})$, em concentrações similares àquelas encontradas na literatura (Hwa Cho et al., 2006; Lombardo et al., 2009; Tomchuck et al., 2008). 24 horas após o tratamento com ligantes para TLR, o meio de cultura foi substituído por meio RPMI 1640 (Invitrogen; Carlsbad, CA, EUA), suplementado com $50 \mathrm{U} / \mathrm{ml}$ de penicilina e $50 \mu \mathrm{g} / \mathrm{ml}$ estreptomicina e $10 \%$ de soro bovino fetal, no sentido de proporcionar as condições ótimas de proliferação dos linfócitos a serem co-cultivados durante o ensaio de imunossupressão.

\subsection{Separação imunomagnética dos linfócitos $\mathbf{T}$}

A separação imunomagnética da população de linfócitos T foi realizada com auxílio do kit comercial: Pan T Cell Isolation Kit II, human (Miltenyi Biotec; Bergisch Gladbach, Alemanha), segundo as instruções do fabricante. Resumidamente, após a obtenção das PBMC, as células não-T (B, NK, $\gamma / \delta$, monócitos, células dendríticas, granulócitos, plaquetas e eritrócitos) foram marcadas, ao serem incubadas com $10 \mu 1 / 10^{7}$ células de um coquetel de anticorpos biotinilados contra CD14, CD16, CD19, CD56, CD36, CD123, TCR $\gamma / \delta$ e CD235a. Em seguida, foram adicionados $30 \mu 1 / 10^{7}$ células de tampão de coluna (PBS, 0,6\% ACD e $0,5 \%$ albumina) e $20 \mu 1 / 10^{7}$ células de partículas magnéticas (beads) ligadas a anticorpos anti-biotina, possibilitando a sua ligação a células marcadas com anticorpos. Deste modo, as células foram dispostas em uma coluna separadora LS (Miltenyi Biotec; Bergisch Gladbach, Alemanha) na presença de um imã SuperMACS (Miltenyi Biotec; Bergisch Gladbach, Alemanha), sendo lavadas com tampão de coluna (PBS 1X, 0,6\% ACD e 0,5\% 
albumina) no intuito de reter as células não-T na coluna separadora. Finalmente, as células T isoladas foram lavadas com tampão de coluna a $1.500 \mathrm{rpm}$ por 10 minutos, ressuspensas em PBS e utilizadas para marcação intracelular ou análise de pureza.

Para análise da pureza e caracterização da composição da amostra em citometria de fluxo, cerca de $2 \times 10^{5}$ células foram dispostas em dois tubos de ensaio contendo $100 \mu \mathrm{l}$ de PBS, sendo em um destes adicionado $5 \mu 1$ do anticorpo anti-CD3 conjugado a FITC (Becton Dickinson, San Jose, CA, EUA) e ao outro (controle) adicionado $5 \mu 1$ de isotipo controle IgG1 FITC, IgG2a PE (BD-Biosciences; San Diego, CA, EUA), por um período de incubação de 20 minutos a temperatura ambiente. As amostras foram então centrifugadas a $1800 \mathrm{rpm}$ por 5 minutos, sendo então descartado o sobrenadante e as células ressuspensas em uma solução de Formol a 2\% em PBS, para então serem analisadas por citometria de fluxo. Durante a análise no sofware Flow Jo VX, foi estabelecido o quadrante correspondente a intensidade de fluorescência observada pelas células incubadas com o isotipo controle, sendo então utilizado para mensurar a porcentagem de células T CD3+, na população de células marcadas com o anticorpo anti-CD3 conjugado a FITC.

\subsection{Marcação intracelular dos linfócitos T}

Os linfócitos $\mathrm{T}$, isolados por separação magnética, foram marcados com auxílio do kit comercial CellTrace ${ }^{\mathrm{TM}}$ CFSE Cell Proliferation Kit (INVITROGEN; San Diego, CA, EUA). Este produto contém CFSE, que difunde passivamente para o interior das células, reagindo com grupos aminas intracelulares e formando compostos fluorescentes que permanecerão retidos nas células. Deste modo, após a divisão celular, os compostos fluorescentes são divididos entre as células filhas, reduzindo a fluorescência das células, o que permite a avaliação indireta da proliferação celular através da determinação da fluorescência por 
citometria de fluxo, pois uma menor fluorescência irá necessariamente corresponder a uma maior proliferação celular (Figura 7).

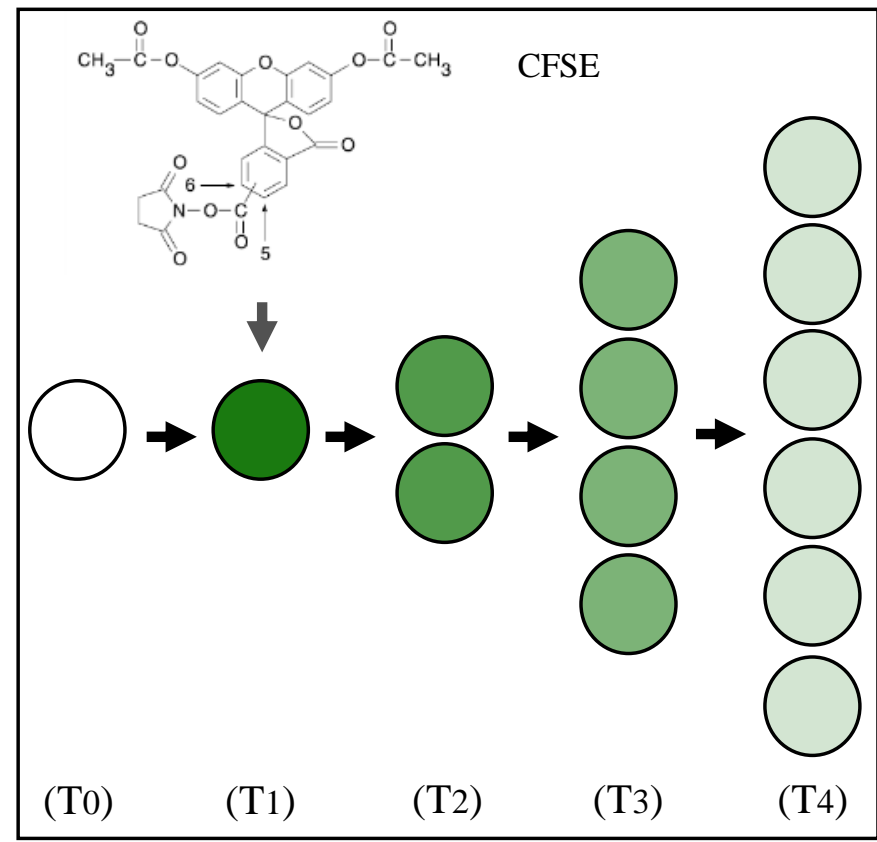

Figura 7. Ilustração acerca da perda de intensidade de fluorescência do corante intracelular CFSE, a partir do momento de adição do corante (T1) e divisões celulares subsequentes (T2; T3; T4).

Seguindo as especificações do fabricante, os linfócitos $T$ isolados por separação imunomagnética foram incubados por 10 minutos com uma solução a $2 \%$ de albumina bovina em PBS, contendo $5 \mu \mathrm{M}$ de CFSE. Após este período, foi adicionado meio RPMI a $0^{\circ} \mathrm{C}$, permanecendo as células por 5 minutos em gelo, sendo efetuadas então 3 lavagens com meio RPMI, a $1500 \mathrm{rpm}$ por 10 minutos, seguido da determinação da quantidade de células por contagem em câmara de Neubauer. Em seguida, uma alíquota de células marcadas foram cultivadas isoladamente em uma placa de cultura celular de 24 poços, servindo como um grupo controle negativo, correspondente a células não induzidas a proliferação.

\subsection{Ativação dos linfócitos $T$ e co-cultivo com células-tronco mesenquimais}

Com o intuito de mimetizar a indução in vivo de ativação dos linfócitos (Figura 8), fenômeno envolvido em respostas imunes relacionadas a doenças autoimunes e na DECH, foi 
utilizado o produto comercial: $\mathrm{T}$ cell activation/expansion kit, human (Miltenyi Biotec; Bergisch Gladbach, Alemanha), segundo as instruções do fabricante. Resumidamente, a partir de reagentes fornecidos pelo fabricante, foi feita uma solução composta por anticorpos biotinilados contra os receptores $\mathrm{CD} 2, \mathrm{CD} 3$ e CD28, ao qual foi adicionado partículas (beads) e uma solução tampão (PBS, $0.5 \%$ albumina sérica humana e $2 \mathrm{mM}$ ACD), sendo posicionada em um rotor de tubo PTR-35 (GRANT; Cambridge, Reino Unido) mantido a $4^{\circ} \mathrm{C}$, por duas horas, no intuito de permitir a ligação entre beads e anticorpos. Após este período, foi adicionado meio RPMI para atingir uma concentração de $2 \times 10^{7}$ bead/500 $\mu 1$, sendo uma alíquota da solução transferida para os linfócitos marcados com CFSE, a uma razão linfócito:bead de 2:1, por um período de 5 minutos.

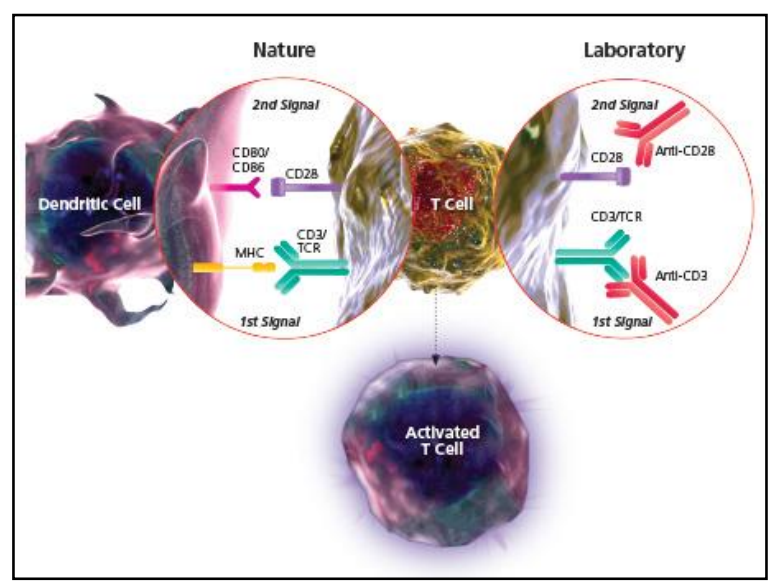

Figura 8. Ilustração acerca do processo in vivo e in vitro de ativação dos linfócitos $\mathrm{T}$, sendo o último realizado a partir do kit comercial: $\mathrm{T}$ cell activation/expansion kit, human (Miltenyi Biotec). Extraído de http://www.ebioscience.com/.

Após este período, os linfócitos ativados foram cultivados isoladamente para formação do grupo controle positivo, correspondente a linfócitos induzidos a proliferação, ou co-cultivados com as CTM a razões linfócitos:CTM de 5:1, 10:1 ou 20:1, no intuito de observar as razões quais são observadas a imunossupressão. Posteriormente, intuito de padronizar o período de tempo necessário para se observar a atividade imunossupressora das CTM, os linfócitos ativados foram cultivados isoladamente ou co-cultivados com as CTM, a uma razão de 10:1, 
por períodos de 3 e 5 dias, sendo neste último caso adicionado 100U de IL-2 após três dias de incubação. A partir dos resultados destas padronizações, foram estabelecidas diretrizes acerca tanto da razão linfócitos:CTM quanto do período de co-cultivo, utilizadas em ensaios de imunossupressão posteriores, no intuito de avaliar a modulação no potencial imunossupressor das CTM.

Para avaliar a modulação na imunossupressão de CTM, em virtude da estimulação com agonistas de TLR, os linfócitos marcados e ativados foram co-cultivados com CTM previamente estimuladas ou não com ligantes para TLR, a razão de 10:1 linfócitos:CTM, sendo também cultivados isoladamente. Devido ao CFSE ser extremamente fotossensível, as placas de cultura celular contendo linfócitos ou linfócitos co-cultivados com CTM foram cobertas com papel alumínio e incubadas em uma estufa de $\mathrm{CO} 2$, por um período de cinco dias, sendo adicionadas $100 \mathrm{U}$ de IL-2 por ml após três dias de incubação.

\subsection{Avaliação da imunossupressão exercida por células-tronco mesenquimais}

Ao final do período de co-cultivo, as células foram removidas dos poços de cultura e a magnitude da fluorescência dos linfócitos, em cada condição experimental, foi avaliada por citometria de fluxo no canal FL-1, correspondente ao espectro de emissão de fluorescência do CFSE. Uma vez adquiridas as células no citômetro, com auxílio do software Flowjo VX, a população de linfócitos foi isolada das demais a partir da estratégia de gate, para análise da intensidade de fluorescência somente nesta população de interesse. Tendo em vista que a magnitude de fluorescência observada no controle negativo corresponde a uma situação de ausência de divisão celular, a magnitude de proliferação celular do controle positivo, bem como a dos linfócitos ativados e co-cultivados com as CTM, foi determinada pela porcentagem de eventos com intensidade de fluorescência inferior ao apresentado pelo controle negativo (Figura 9). 


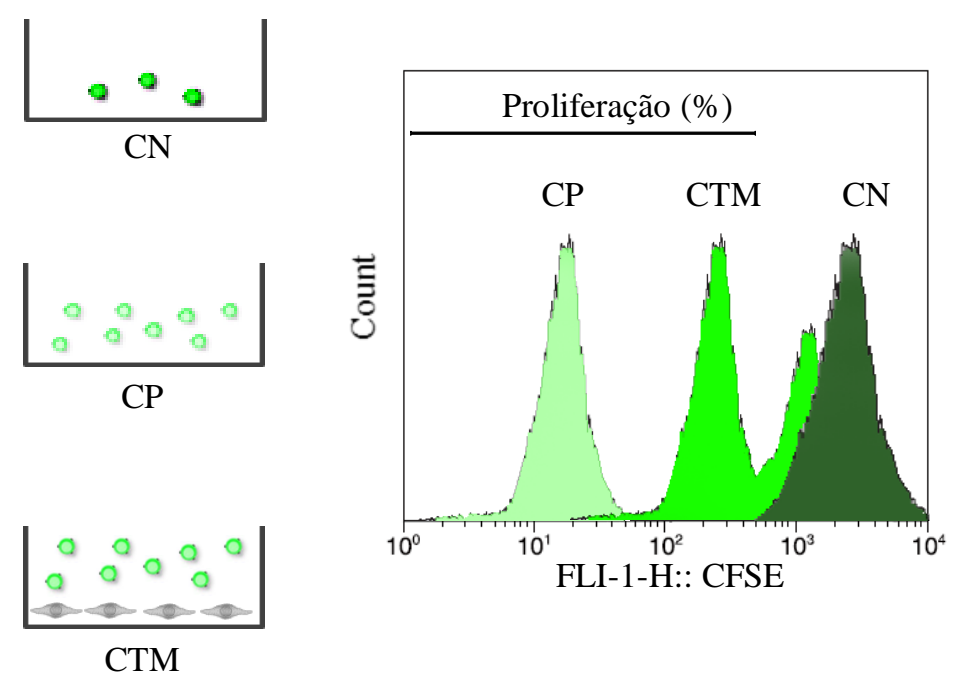

Figura 9. Ilustração acerca das intensidades de fluorescência do corante CFSE, mensuradas após ensaios de imunossupressão, em linfócitos não ativados $(\mathrm{CN})$, ativados e cultivados isoladamente $(\mathrm{CP})$ e co-cultivados com as CTM (CTM).

Para tornar possíveis comparações entre diferentes ensaios, os resultados foram normalizados, de modo similar ao realizado por trabalhos publicados anteriormente (Waterman et al., 2010; Venken et al., 2007), quais a intensidade de fluorescência observada pelo controle positivo foi sempre considerada como indicativa de $100 \%$ de proliferação celular. Deste modo, a proliferação relativa dos linfócitos em cada condição de co-cultivo, foi determinada como a porcentagem de proliferação celular em relação àquela apresentada pelo controle positivo. Estes dados foram obtidos a partir da compilação das porcentagens de proliferação celular referentes ao controle positivo e condições de co-cultivo, no software Microsoft Excel, a partir do qual foi calculada a proliferação celular relativa, com uso da equação: $\mathrm{X} * 100 / \mathrm{Y}$, qual "X" e "Y" são valores correspondentes as percentagens de proliferação celular correspondentes as condições de co-cultivo e controle positivo, respectivamente. 


\subsection{Avaliação de alterações na proliferação celular - High Content Screening (HCS)}

A descoberta de ligantes que alterem a proliferação celular apresenta o potencial no aprimoramento tanto de protocolos de terapia celular, visando uma expansão mais eficiente de células, quanto em imunoterapias, tendo em vista uma maior expansão de células infundidas provavelmente levará a uma atividade imunossupressora de maior magnitude. Com isso em vista, foi realizado um ensaio baseado em imunofluorescência, acerca da capacidade de agonistas de receptores do tipo Toll em induzir um aumento na quantidade de CTM, marcadas com o corante intracelular CellMask ${ }^{\mathrm{TM}}$ Deep Red (Invitrogen; Carlsbad, CA, EUA). O corante CellMask $^{\mathrm{TM}}$ utilizado neste ensaio consiste em moléculas anfipáticas que apresentam um radical lipofílico, que proporciona sua ligação em membranas celulares, além do corante hidrofílico negativamente carregado, possibilitando a demarcação dos compartimentos nucleares e citoplasmático.

Para realização deste ensaio, CTM em réplicas experimentais $(n=12)$ foram cultivadas em placas de 96 poços de fundo claro (Corning Costar; Cambridge, MA, EUA), a 2x10³ células por poço e por $24 \mathrm{~h}$, sendo posteriormente tratadas ou não com os agonistas: LPS $(1 \mu \mathrm{g} / \mathrm{ml})$, DSP30 $(1 \mu \mathrm{M})$, CpG-A $(1 \mu \mathrm{g} / \mathrm{ml})$, CpG-B $(1 \mu \mathrm{g} / \mathrm{ml})$ e POLY IC $(1 \mu \mathrm{g} / \mathrm{ml})$, por $24 \mathrm{~h}$. Após este período, as células foram lavadas por duas vezes com $200 \mu \mathrm{l}$ de PBS, permeabilizadas com $100 \mu 1$ de uma solução a 1X do reagente TRITON-X100 (Sigma-Aldrich; Steinhein, Alemanha), lavadas por duas vezes com $200 \mu \mathrm{l}$ de PBS e marcadas com $100 \mu \mathrm{l}$ de uma solução contendo o corante CellMask ${ }^{\mathrm{TM}}$ Deep Red (Invitrogen; Carlsbad, CA, EUA), por 20 minutos, seguido por duas lavagens com $200 \mu 1$ de PBS e fixação com $100 \mu 1$ de uma solução de formol a $2 \%$ em PBS. Finalmente, as células foram lavadas com $200 \mu 1$ de PBS e dispostas em um aparelho de High Content Screening (HCS): ImageXpress micro XL (Molecular Devices, Sunnyvale, CA). 
No HCS, através do software MetaXpress foi selecionada uma objetiva de $20 \mathrm{X}$ e adquiridas quatro imagens por poço da placa de cultura, sendo selecionado o módulo de análise de imagens "Cell Scoring”, a partir do qual foi possível estabelecer a área média e intensidade de fluorescência correspondente ao citoplasma, permitindo identificar as células presentes em cada campo do poço de cultura. Adicionalmente, como análise subsequente a aquisição das imagens, foi selecionada a opção "Total Cells", para ser informado a quantidade total de células em cada campo dos poços da placa de cultura celular. Estes resultados foram exportados para planilhas do software Microsoft Excel, sendo então somadas as quantidades de células por campo e obtidas as quantidades de células totais por poço da placa de cultura.

\subsection{Avaliação de alterações na proliferação celular - Síntese de DNA}

Para avaliar os resultados preliminares obtidos no ensaio em HCS, foi realizado um experimento no intuito de observar a magnitude de DNA sintetizado pelas CTM, estimuladas com determinados ligantes para TLR, com auxílio do kit comercial: Click-iT® EdU Alexa Fluor® 488 Flow Cytometry (Life Technologies, Paisley, UK) e de acordo com as normas do fabricante. Resumidamente, o uso deste produto permite avaliar a quantidade de DNA sintetizado a partir da incubação das células com nucleosídeos análogos a Timidina (EdU), que são modificados no sentido de serem acessíveis ao fluoróforo Alexa Fluor ${ }^{\circledR}$ 488, ambos fornecidos pelo fabricante. Deste modo, durante a divisão celular, a magnitude de incorporação dos nucleosídeos (e consequentemente, de células em divisão) incorporados pelas células é determinada indiretamente, a partir da mensuração da intensidade de fluorescência do fluoróforo Alexa Fluor® 488, através da citometria de fluxo no canal FL-1.

Para avaliar alterações na proliferação celular, CTM obtidas de três doadores foram cultivadas em placas de 6 poços, a $2 \times 10^{5}$ célula por poço e por $24 \mathrm{~h}$, sendo então tratadas com os ligantes: LPS $(1 \mu \mathrm{g} / \mathrm{ml})$, DSP30 $(1 \mu \mathrm{M})$, CpG-A $(1 \mu \mathrm{g} / \mathrm{ml})$ e CpG-B $(1 \mu \mathrm{g} / \mathrm{ml})$, por 24h. Após 
este período, foi adicionado ao meio de cultura uma solução contendo nucleosídeos EdU, a uma concentração final de $10 \mu \mathrm{M}$, a uma período de incubação e $24 \mathrm{~h}$. Após este período, as células foram ressuspensas em PBS a $0^{\circ} \mathrm{C}$, sendo lavadas em PBS a $1.500 \mathrm{rpm}$ por 10 minutos, sendo ressuspensas e fixadas com $100 \mu 1$ do reagente "Click-iT® fixative", por 15 minutos. Em seguida, as células foram lavadas em PBS a $1.500 \mathrm{rpm}$ por 10 minutos, seguido de permeabilização com adição de $100 \mu$ do reagente fornecido pelo fabricante: “Click-iT® saponin-based permeabilization and wash reagent", sendo adicionado em seguida $500 \mu \mathrm{um}$ coquetel de reagentes, cujo está incluso o fluoróforo Alexa Fluor® 488. Após 30 minutos de incubação, as células foram lavadas com o reagente: "Click-iT® saponin-based permeabilization and wash reagent" a $1.500 \mathrm{rpm}$ por 10 minutos, sendo ressuspensas em PBS e determinadas as magnitudes de incorporação do nucleosídeo EdU, com auxílio da citometria de fluxo e posterior análise no software Flow Jo VX.

\subsection{Extração de RNA}

As amostras de CTM obtidas de diferentes doadores $(n=5)$, cultivadas em placas de 6 poços a $2 \times 10^{5}$ célula por poço e por $24 \mathrm{~h}$, foram estimuladas com os agonistas LPS $(1 \mu \mathrm{g} / \mathrm{ml})$, DSP30 $(1 \mu \mathrm{M})$ ou ambos, por $24 \mathrm{~h}$, sendo então ressuspensas em $250 \mu \mathrm{l}$ de uma solução composta de PBS e DEPC (Dietilpirocarbonato; Sigma-Aldrich, Steinhein, Alemanha). Posteriormente, foi adicionado $750 \mu \mathrm{l}$ de TRIZOL (solução monofásica de fenol e isotiocianato de guanidina - Invitrogen, Carlsbad, CA, EUA), sendo as amostras transferidas para um freezer a $-80^{\circ} \mathrm{C}$, até o momento da extração do RNA.

Para extrair o RNA, as amostras foram descongeladas e em seguida foi adicionado 10 $\mu \mathrm{l}$ de glicogênio e $200 \mu \mathrm{l}$ de clorofórmio, sendo então centrifugadas a $14.000 \mathrm{rpm}$ por 15 minutos a $4^{\circ} \mathrm{C}$. Em seguida, foram retirados os anéis formados em cada amostra, transferindoos a outros tubos quais foram adicionados $500 \mu \mathrm{l}$ de isopropanol gelado, a um período de 
incubação de 15 minutos a temperatura ambiente, no intuito de precipitar o material, que em seguida foi centrifugado a $14000 \mathrm{rpm}$ por 15 minutos a $4^{\circ} \mathrm{C}$, sendo descartado o sobrenadante.

O pellet formado foi ressuspenso em etanol $70 \%$ e centrifugado a $14.000 \mathrm{rpm}$ por 10 minutos a $4^{\circ} \mathrm{C}$, em seguida, o sobrenadante foi descartado e o pellet ressuspenso em $15 \mu 1$ de água livre de RNAse, sendo as amostras então congeladas em um freezer $-80^{\circ} \mathrm{C}$. O RNA total obtido das amostras foi quantificado no espectrofotômetro NanoVuePlus (GE Healthcare; Piscataway, NJ, EUA) através do comprimento de onda de $260 \mathrm{~nm}$, sendo utilizado a equivalência de $40 \mu \mathrm{g} / \mathrm{ml}$ para 1 unidade de absorbância. $\mathrm{O}$ grau de pureza das amostras foi avaliado através da razão 260/280 nm, sendo considerada uma boa extração aquela que apresentou valores entre 1,6 e 1,8 .

\subsection{Transcrição reversa}

O RNA extraído $(1 \mu \mathrm{g})$ das amostras foi utilizado para síntese do cDNA, realizada por transcrição reversa a partirdo produto comercial: High Capacity cDNA Archive Kit (AppliedBiosystems, Foster City, CA, EUA), seguindo as instruções do fabricante. As amostras de cDNA resultantes desta reação foram diluídas para uma concentração final de $100 \mathrm{ng} / \mu \mathrm{l}$ em água livre de nucleases (Promega, Madison, WI, EUA), para então serem utilizadas em análises de expressão gênica através de ensaios de PCR quantitativo.

\subsection{Análise de expressão gênica}

A análise de expressão gênica das CTM estimuladas com agonistas para TLR, foi realizada em ensaios de PCR quantitativo (qPCR), com o cDNA das CTM, reagente TaqMan Universal MIX II - NO UNG (AppliedBiosystems; Foster City, CA, EUA) e sondas TaqMan (“Assayondemand”, tabela 1), em um aparelho BioRad CFX96 Real Time System (Bio-Rad, Hercules, CA). As condições de termociclagem compreenderam uma incubação a $50^{\circ} \mathrm{C}$ por 2 minutos, $95^{\circ} \mathrm{C}$ por 10 minutos (ativação da DNA polimerase), seguidos por 40 ciclos de $95^{\circ} \mathrm{C}$ 
por 15 segundos (desnaturação) e $60^{\circ} \mathrm{C}$ por 1 minuto (anelamento e extensão simultâneos), sendo os resultados de CT exportados para planilhas no software Microsoft Excel, utilizando o software Bio-Rad CFX manager.

Os resultados dos ensaios de qPCR (CT), provenientes do cDNA de CTM estimuladas com agonistas para TLR, foram normalizados ao subtrair o valor do CT obtido daquele observado no controle endógeno GAPDH da mesma amostra (obtendo o valor de $\Delta \mathrm{Ct}$ ). Para calcular a expressão relativa $\left(2^{-\Delta \Delta C t}\right)$ das CTM estimuladas com agonistas para TLR, foi utilizada a condição das CTM não estimuladas.

\begin{tabular}{|c|c|}
\hline Símbolo do Gene & ID Sonda \\
\hline IL-1 $\beta$ & Hs00174097_m1 \\
\hline IL-4 & Hs00929862_m1 \\
\hline IL-10 & Hs00174086_m1 \\
\hline TGF $\beta$ & Hs00171257_m1 \\
\hline
\end{tabular}

Tabela1. Sondas específicas a citocinas inflamatórias provenientes da applied biosystem.

\subsection{Ensaio de imunoprecipitação de cromatina (ChIP)}

Para realização do ensaio de imunoprecipitação de cromatina (ChIP), células foram cultivadas em garrafas de cultura celular de $175 \mathrm{~cm}^{2}$ até atingirem a confluência de aproximadamente $80 \%$. Em seguida, as células foram tratadas ou não com LPS $(1 \mu \mathrm{g} / \mathrm{ml})$, DSP30 $(1 \mu \mathrm{M})$ ou ambos, por um período de seis horas, após o qual foi realizado o ensaio de ChIP utilizando o kit comercial: Magna ChIPTM G (Millipore; Billerica, MA, EUA). Este ensaio consiste em isolar e fragmentar a cromatina (DNA e histonas) a partir de células ou tecidos, preservando a ligação de fatores de transcrição ao DNA e possibilitando o posterior isolamento dos fatores de transcrição juntamente ao fragmento de DNA conjugado, o que é feito através de anticorpos específicos, permitindo avaliações por qPCR acerca da força de ligação qual um determinado fator de transcrição está ligado a determinados genes (figura $10)$. 


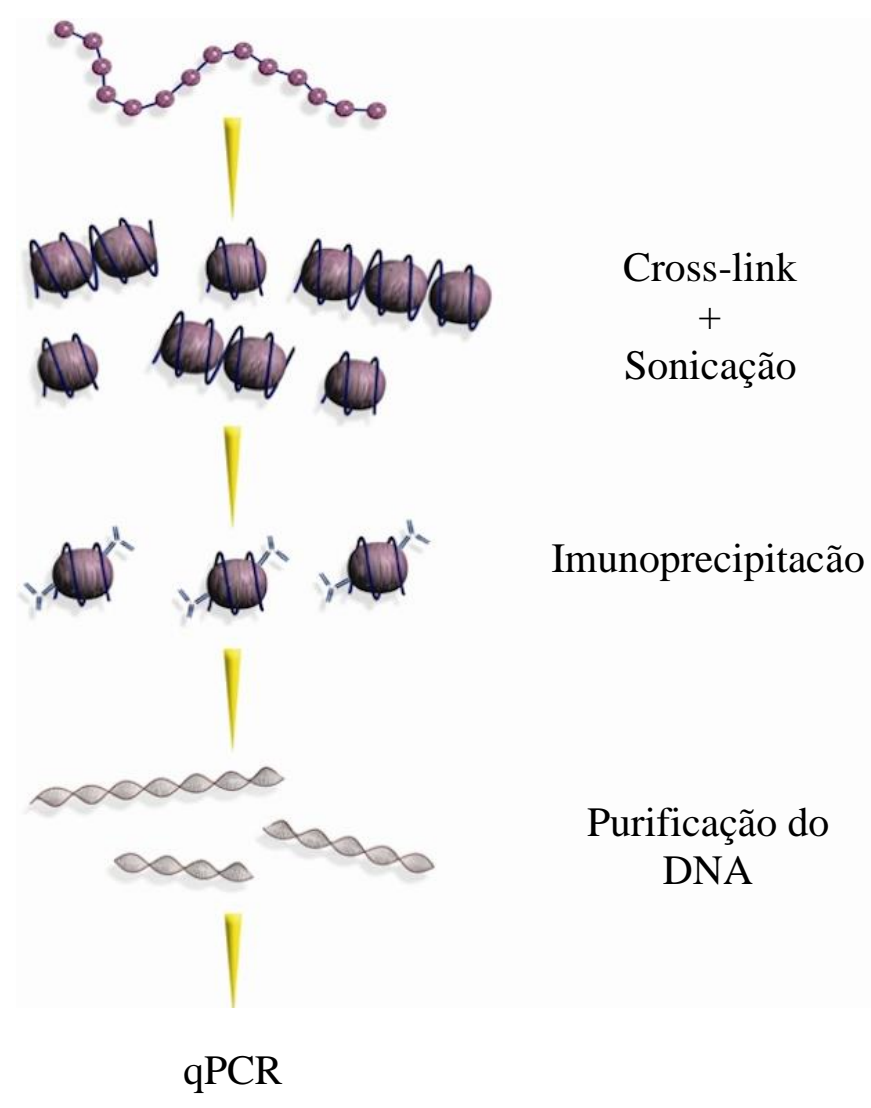

Figura 10. Ilustração geral do ensaio de imunoprecipitação de cromatina (ChIP), destacando as etapas de crosslink, sonicação, imunoprecipitação, purificação do DNA e qPCR. Modificado de: http://www.millipore.com/.

Após o período de tratamento e de acordo com as instruções de fabricante, foi realizado o crosslink das células com a adição de formaldeído (concentração final de 1\%) para estabilização das ligações proteína-DNA, sendo adicionado $125 \mathrm{mM}$ de glicina após 15 minutos, seguido de incubação de gelo por 5 minutos, para neutralizar a reação. Posteriormente, foi adicionado um coquetel inibidor de protease II e as células foram removidas mecanicamente com auxílio de um raspador de células (Greiner Bio One; Frickenhausen, Alemanha), seguido da adição dos reagentes de lise celular e lise nuclear com incubação em gelo por 10 minutos para cada reagente. A fragmentação do DNA foi realizada utilizando o aparelho Sonics VibraCell VCX130 (Sonics; Newtown, CT, EUA) no qual foram realizados 6 ciclos de sonicação de 30 segundos com 30\% de amplitude e 30 segundos de descanso em gelo, gerando assim o DNA genômico fragmentado. A imunoprecipitação foi

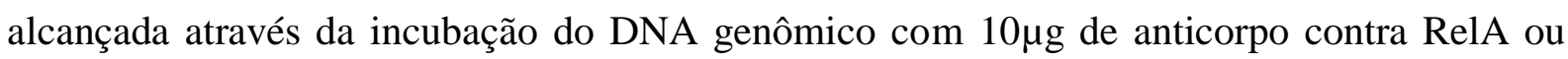


RelB (Santa Cruz Biotechnology; Santa Cruz, CA, EUA) ou IgG humano como controle negativo inespecífico. Após a obtenção da cromatina imunoprecipitada, a reação de crosslink foi revertida com digestão com RNAse A $(10 \mathrm{mg} / \mathrm{ml})$ e Proteinase K $(10 \mathrm{mg} / \mathrm{ml})$ e passos de eluição e lavagens do DNA com os reagentes fornecidos pelo fabricante, para obtenção do DNA purificado, que em seguida foi sujeito a ensaios de PCR quantitativo para avaliar alterações na força de ligação dos fatores de transcrição das vias canônica e não canônica NF$\kappa \mathrm{B}$.

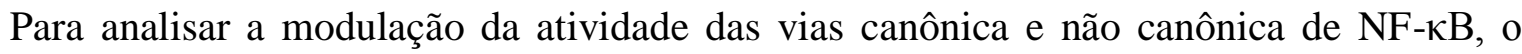
DNA imunoprecipitado (DNA IP) foi sujeito as reações de qPCR, utilizando primers $\begin{array}{llllll}\text { específicos para } & \text { a } & \text { região } & \text { promotora do gene }\end{array}$ (F:AGCTTCAGCAGTGAGAGCAAC; R:AAAGGGTCTTGTTGCAGAGG), desenhados com auxílio das ferramentas Blat (http://genome.ucsc.edu/cgi-bin/hgBlat) e Primer3Plus (http://primer3plus.com). As reações de qPCR foram realizadas em duplicata, utilizando os primers, o reagente Power SYBR®Green (AppliedBiosystems, Foster City, CA, EUA) e as amostras de DNA, no aparelho 7300 Real Time PCR System (AppliedBiosystems, Foster City, CA, EUA). As condições de termociclagem compreenderam uma incubação de $50^{\circ} \mathrm{C}$ por 2 minutos, em seguida $95^{\circ} \mathrm{C}$ por 10 minutos (para ativação da DNA polimerase), e por fim 40 ciclos de $95^{\circ} \mathrm{C}$ por 15 segundos (desnaturação) e $60^{\circ} \mathrm{C}$ por 1 minuto (anelamento e extensão simultâneos), sendo os resultados de CT exportados para planilhas no software Microsoft Excel, utilizando software Sequence Detection System V1.3.

Os resultados dos ensaios de qPCR (CT) foram normalizados, ao subtrair o valor do CT obtido daquele observado no controle endógeno GAPDH da mesma amostra (obtendo o valor de $\Delta \mathrm{Ct}$ ). Para o cálculo dos valores de expressão relativa $\left(2^{-\Delta \Delta \mathrm{Ct}}\right)$, foi utilizada a condição do DNA fragmentado, mas não imunoprecipitado, sendo os valores das amostras estimuladas 
com ligantes para TLR normalizados com base no valor encontrado na amostra não estimulada.

\subsection{Avaliação da modulação da via não-canônica NF-кB - High Content Screening} (HCS)

Tendo em vista os resultados observados a partir do ensaio de ChIP, foi realizado um ensaio para avaliar alterações na atividade da via não canônica $\mathrm{NF}-\kappa \mathrm{B}$, por meio de técnicas de imunofluorescência. Este ensaio possibilita visualizar a localização celular da proteína de interesse, utilizando-se anticorpos marcados com fluoróforos. As áreas do núcleo e citoplasma foram marcadas com o uso de marcadores específicos, e a proteína RelB foi marcada com anticorpos primários anti-RelB, seguida de uma marcação com anticorpos secundários fluorescentes contra os primários.

Para tanto, CTM provenientes de três doadores foram cultivadas em placas de 96 poços de

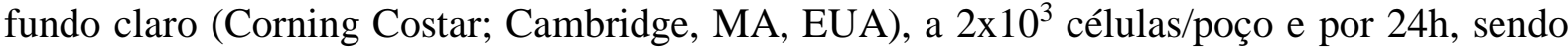
em seguida estimuladas com LPS $(1 \mu \mathrm{g} / \mathrm{ml})$, DSP30 $(1 \mu \mathrm{M})$ ou ambos os reagentes simultaneamente, por um período de $6 \mathrm{~h}$. Após o período de tratamento o meio de cultura foi removido e as células lavadas por duas vezes com $200 \mu 1$ de PBS, sendo adicionados $100 \mu \mathrm{L}$ de Metanol absoluto a $0^{\circ} \mathrm{C}$, por cinco minutos, com intuito de fixar e permeabilizar as células. Após a remoção do metanol e secagem ao ar livre por 5 minutos, foram adicionados $100 \mu \mathrm{l}$ de PBS contendo soro fetal bovino a $1 \%$ por uma hora, a temperatura ambiente, no intuito de bloquear as ligações inespecíficas. Passado este período, as células foram lavadas por três vezes com $200 \mu 1$ de PBS, sendo então adicionado $50 \mu 1$ dos anticorpos primários específicos para RelB (IgG de coelho, Santa Cruz Biotechnology; Santa Cruz, CA, EUA) a 2,5 $\mu \mathrm{g} / \mathrm{ml}$, seguido de incubação por uma hora e duas lavagens com $200 \mu \mathrm{l}$ de PBS. Posteriormente, foi adicionado $10 \mu \mathrm{g} / \mathrm{ml}$ de anticorpos secundários conjugados com FITC, específicos aos 
anticorpos primários (anti-IgG de coelho, Life Technologies; Grand Island, NY), por um período de incubação de uma hora.

No intuito de corar o citoplasma celular, as células foram então lavadas por três vezes com $200 \mu 1$ de PBS, marcadas com $100 \mu 1$ de uma solução contendo o corante CellMask ${ }^{\mathrm{TM}}$, contido no produto comercial HCS CellMask ${ }^{\mathrm{TM}}$ Deep Red (Invitrogen; Carlsbad, CA, EUA), por 20 minutos, seguido de duas lavagens com $200 \mu \mathrm{l}$ de PBS. Em seguida, no intuito de marcar a região nuclear, as células foram incubadas com uma solução de DAPI a 0,3 nM (Life Technologies; Grand Island, NY, EUA), por cinco minutos, seguido de duas lavagens com $200 \mu 1$ de PBS.

Finalmente, a placa de cultura celular foi disposta no aparelho de HCS, sendo selecionada uma objetiva de 10X para aquisição de imagens, correspondentes a quatro campos de cada poço da placa de cultura celular. Através do software MetaXpress, foi selecionado o módulo de análise de imagens "multi-wavelength cell scoring", a partir do qual foi possível estabelecer a área nuclear e citoplasmática ao serem selecionados os filtros correspondentes aos espectros de emissão do DAPI e CellMask ${ }^{\mathrm{TM}}$ Deep Red, respectivamente, que tiveram a sua intensidade mínima de fluorescência (treshold) e área determinadas. Finalmente, a partir do mesmo módulo de análises foi selecionado o filtro correspondente ao espectro de emissão do FITC e analisada a intensidade média de fluorescência correspondente a presença de RelB no núcleo (Nucleus Average Intensity) e citoplasma (Cytoplasm Average Intensity). Os resultados destas análises foram sumarizados em uma planilha no software Microsoft Excel e submetidos a análises estatísticas, no intuito de observar possíveis alterações na magnitude da presença da proteína RelB, nos diferentes compartimentos celulares. 


\subsection{Eficiência do protocolo de marcação com anticorpos anti-TLR}

Tendo em vista as contradições presentes na literatura acerca da expressão dos receptores do tipo Toll em CTM, um protocolo de marcação com anticorpos anti-TLR foi primeiramente avaliado quanto a sua eficiência em monócitos isolados de PBMC, para então ser utilizado em CTM de medula óssea.

Como esperado, foi observado que os monócitos, isolados através da estratégia de gate, apresentaram níveis elevados para todos os TLR avaliados, confirmando a eficiência dos anticorpos e do protocolo de marcação (figura 11). Estes resultados foram então sumarizados para posterior comparação com os níveis de expressão proteica encontrada em CTM (tabela 2). Uma vez observada a sua eficiência, o protocolo utilizado foi selecionado para avaliar os níveis de expressão proteica de receptores do tipo-Toll em CTM de medula óssea.

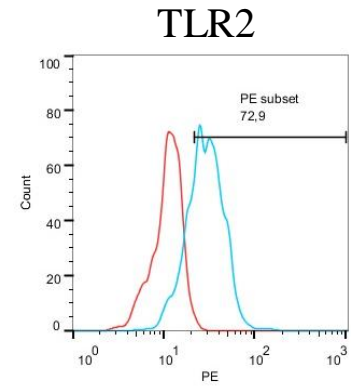

TLR3

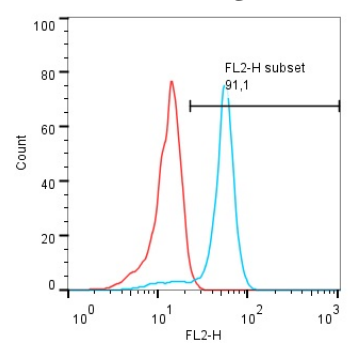

TLR4

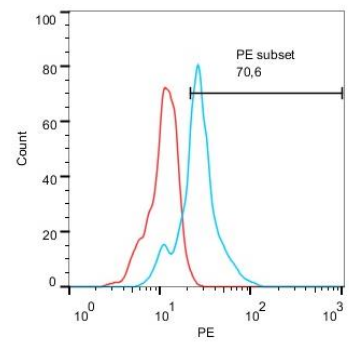

TLR9

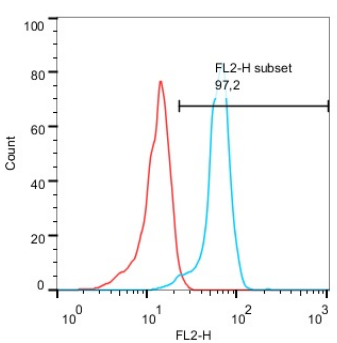

Extracelular

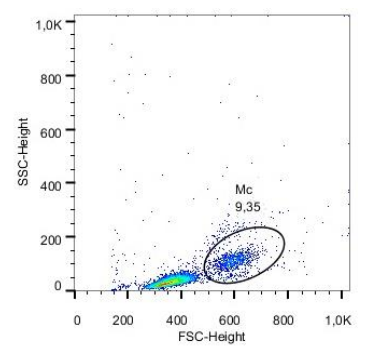

Intracelular

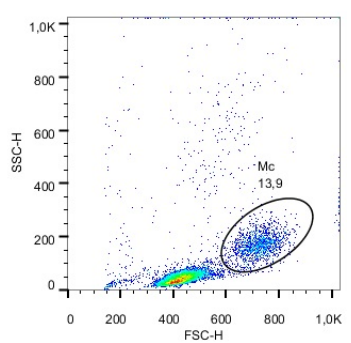

Figura11. Imagens representativas dos resultados dos níveis de expressão proteicos (PE subset) dos receptores do tipo Toll (linha azul): TLR2, TLR3, TLR4 e TLR9, em relação ao isotipo controle (linha vermelha), em monócitos derivados de PBMC, bem como o isolamento por estratégia de gate após as marcações extracelular e intracelular. 


\begin{tabular}{c|c|c|c|c}
\hline & \multicolumn{4}{|c}{ FL2-H Subset } \\
\hline Amostra & TLR2 & TLR3 & TLR4 & TLR9 \\
\hline PBMC 1 & 90,9 & 74,4 & 96,9 & 75,4 \\
PBMC 2 & 92,2 & 65,7 & 93,8 & 72,6 \\
PBMC 3 & 74,4 & 87,85 & 89,8 & 85,1 \\
\hline
\end{tabular}

Tabela2. Níveis de expressão proteica (FL2-H Subset) de receptores do tipo Toll em monócitos isolados de PBMC.

\subsection{Expressão de receptores do tipo Toll em células-tronco mesenquimais de medula} óssea

Devido a observação prévia da eficiência tanto dos anticorpos anti-TLR, quanto do protocolo utilizado, foi avaliada a expressão a níveis proteicos dos receptores do tipo Toll: TLR2, TLR3, TLR4 e TLR9, em CTM de medula óssea. Após este procedimento, foi observada a intensidade de fluorescência para cada TLR em relação ao isotipo controle (figura 12), sendo os dados então sumarizados e comparados com os níveis de expressão apresentados por monócitos derivados de PBMC.

Como resultados, foi observado que as CTM analisadas apresentaram baixos níveis de expressão de TLR2, apresentando níveis de TLR3, TLR4 e TLR9 similares ao observado em monócitos (figura 13). Estes resultados indicam que as células utilizadas pelo presente estudo são capazes de interagir com os ligantes POLY IC, LPS e oligonucleotídeos com motivos CpG, e possivelmente com lipopeptídeo. 
TLR2

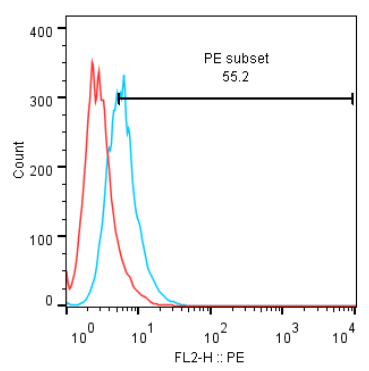

TLR3

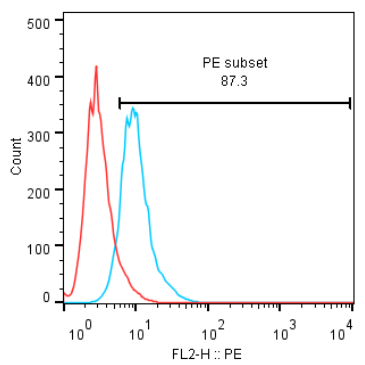

TLR4

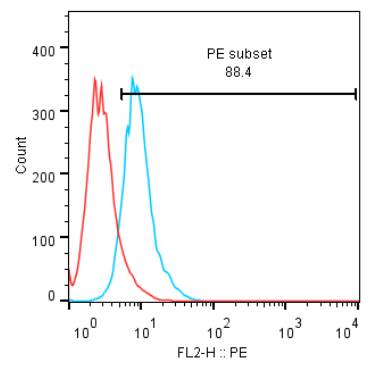

TLR9

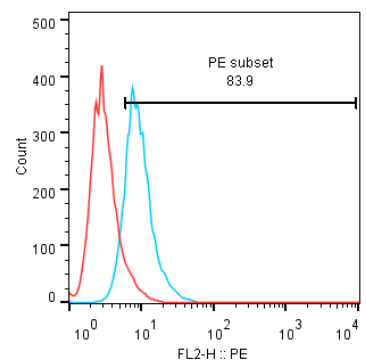

Figura12. Imagens representativas dos resultados dos níveis de expressão proteicos (PE subset) dos receptores do tipo Toll (linha azul): TLR2, TLR3, TLR4 e TLR9, em relação ao isotipo controle (linha vermelha), em CTM derivadas de medula óssea.

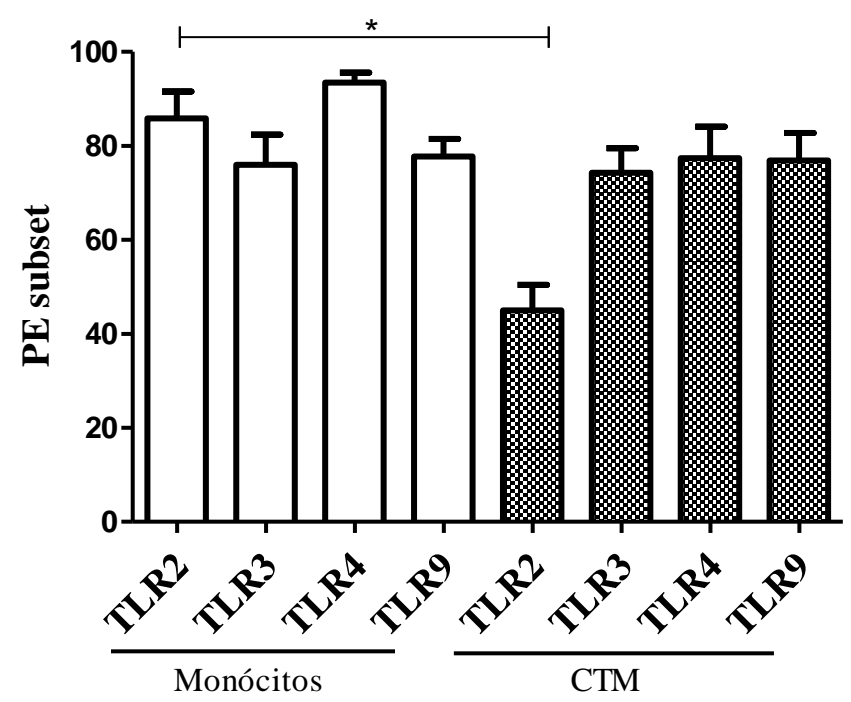

Figura13. Gráfico representando os níveis de expressão proteica (PE subset) dos receptores do tipo Toll: TLR2, TLR3, TLR4 e TLR9, observados em monócitos e CTM derivadas de medula óssea. *diferença estatisticamente significativa $(\mathrm{p}<0.05)$.

\subsection{Análises de pureza da população de linfócitos}

No intuito de avaliar a eficiência do produto comercial: Pan T Cell Isolation Kit II, human (Miltenyi Biotec; Bergisch Gladbach, Alemanha), em isolar os linfócitos T das demais 
populações celulares presentes nas PBMC, alíquotas celulares foram removidas após o procedimento de separação e marcadas com anticorpos isotipo controle ou anti-CD3 FITC. Após a análise por citometria de fluxo, em todo caso foi observada uma eficiência de isolamento superior a 90\%, como visto pela intensidade de fluorescência dos linfócitos marcados com anticorpo anti-CD3 FITC após determinado um intervalo delimitado pela fluorescência observada após a marcação com o isotipo controle (figura 14)

Controle

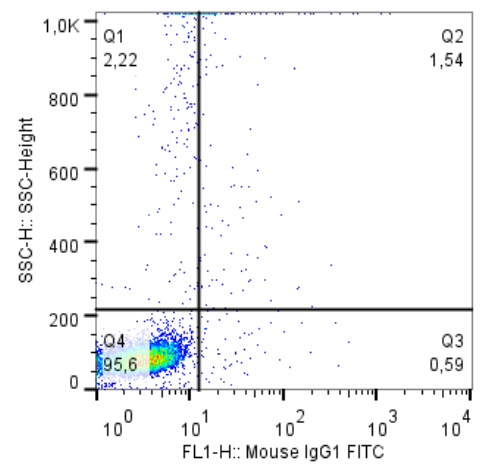

Anti-CD3 FITC

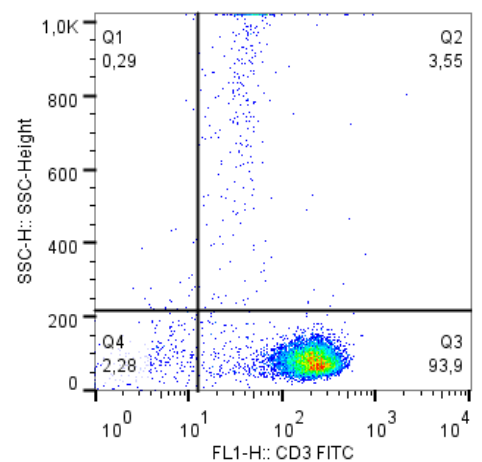

Figura14. Imagens representativas acerca das análises de pureza dos linfócitos T CD3+, isolados por separação imunomagnética, com destaque para o quadrante estabelecido através de amostras marcadas com isotipo controle (controle) a porcentagem de células T CD3+ marcadas com anticorpos anti-CD3 FITC (anti-CD3 FITC).

\subsection{Padronização do período de co-cultivo para o ensaio de imunossupressão}

Devido a necessidades de padronizações acerca do período de co-cultivo necessário para ser observada a imunossupressão, foram comparadas as proliferações de linfócitos após 3 e 5 dias de co-cultivo com as CTM, a uma razão linfócitos:CTM de 5:1. Neste último caso, houve adição de $100 \mathrm{U}$ de IL-2 ao terceiro dia, tendo em vista a necessidade desta citosina para continuação da proliferação dos linfócitos. Como resultados, foi observado que após o isolamento da população de linfócitos através da estratégia de gate, a proliferação dos linfócitos foi similar entre o controle positivo (linfócitos) e os linfócitos co-cultivados com as CTM ao $3^{\circ}$ dia, havendo somente ao $5^{\circ}$ dia, uma proliferação significativamente menor dos linfócitos co-cultivados com as CTM (figura 15). Este período de tempo necessário a 
imunossupressão, possivelmente se deve a necessidade do acúmulo fatores solúveis em concentrações adequadas no meio de cultura, no sentido de inibir a proliferação celular dos linfócitos ativados.

(A)

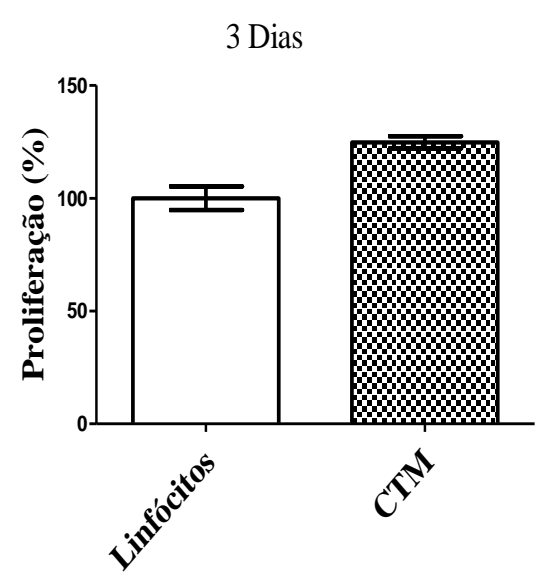

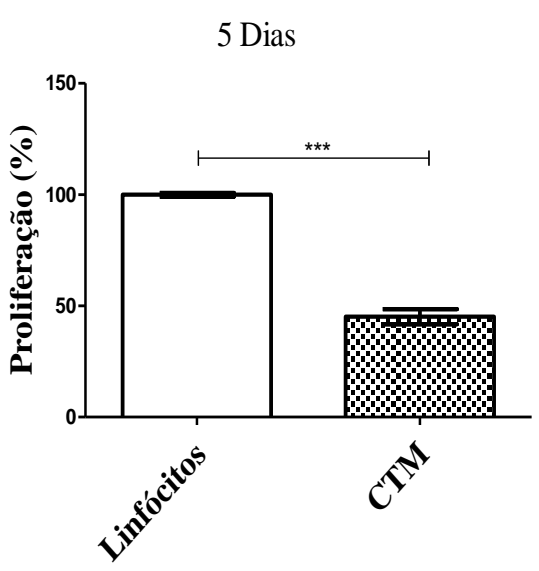

(C)

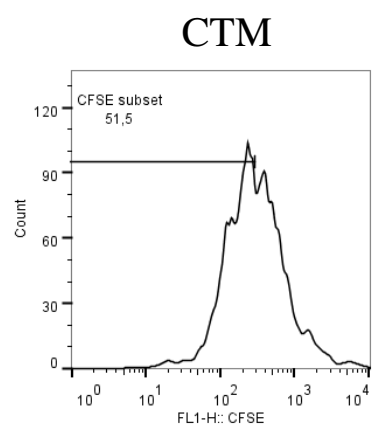

(B)

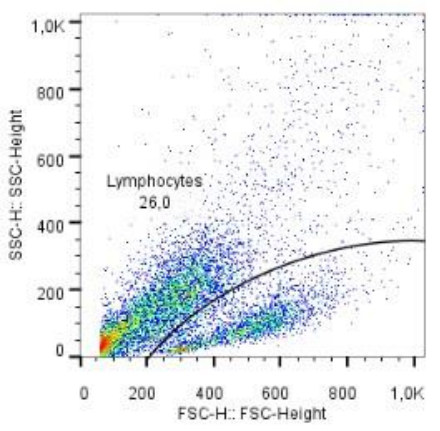

(D)

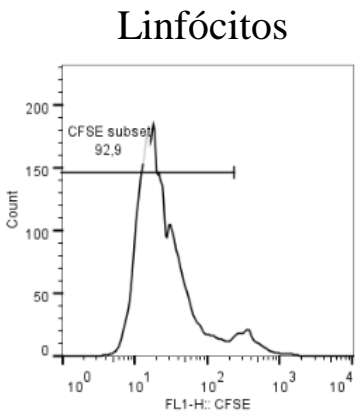

CTM

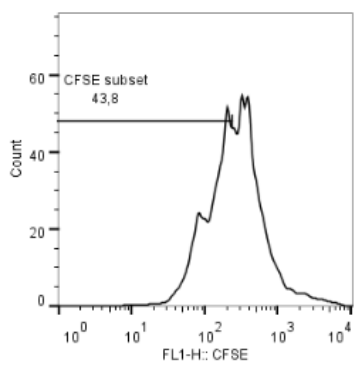

Figura 15. Padronização do período de co-cultivo durante o ensaio de imunossupressão. Gráficos acerca da avaliação da proliferação do controle positivo (linfócitos) ou linfócitos co-cultivados com CTM (CTM), após 3 ou 5 dias (A). Imagem representativa sobre a estratégia de gate para isolamento dos linfócitos a serem analisados quanto a proliferação celular (B). Imagens representativas acerca da perda de intensidade de fluorescência do corante CFSE, no controle positivo (linfócitos) ou linfócitos co-cultivado com CTM (CTM) após 3 dias (C) e 5 $\operatorname{dias}(\mathrm{D})$.

\subsection{Padronização da razão linfócitos:CTM para o ensaio de imunossupressão}

Embora uma razão linfócitos:CTM de 5:1 tenha sido suficiente para ser observada a imunossupressão realizada por CTM, a frequente utilização de razões mais elevadas por estudos anteriores nos fez questionar acerca da possibilidade desta menor quantidade de linfócitos utilizada, ser insuficiente para poder observar modulações em menor magnitude na 
imunorregulação exercida por CTM. Esta possibilidade se faz presente devido ao alto potencial imunossupressor das CTM, que mesmo prejudicada pode ser suficiente para suprimir a proliferação de linfócitos em pequenas quantidade. Com isso em vista, foram avaliados o potencial imunossupressor das CTM após 5 dias de co-cultivo a razões de 5:1, 10:1 e 20:1 (Figura 16).

Como resultados, foi observado que em todas as condições avaliadas o potencial de imunossupressão das CTM foi estatisticamente significativo. De outro modo, quando comparados os potenciais de supressão entre as diferentes condições de co-cultivo, não houveram diferenças significativas, indicando que mesmo em razões elevadas de 20:1, o potencial imunossupressor das CTM mantêm-se essencialmente equivalente ao observado em razões menores. Deste modo, para evitar que alterações de baixa magnitude no potencial imunossupressor das CTM não sejam observadas, a razão de 10:1 foi escolhida para realização dos ensaios de imunossupressão subsequentes. 
(A)
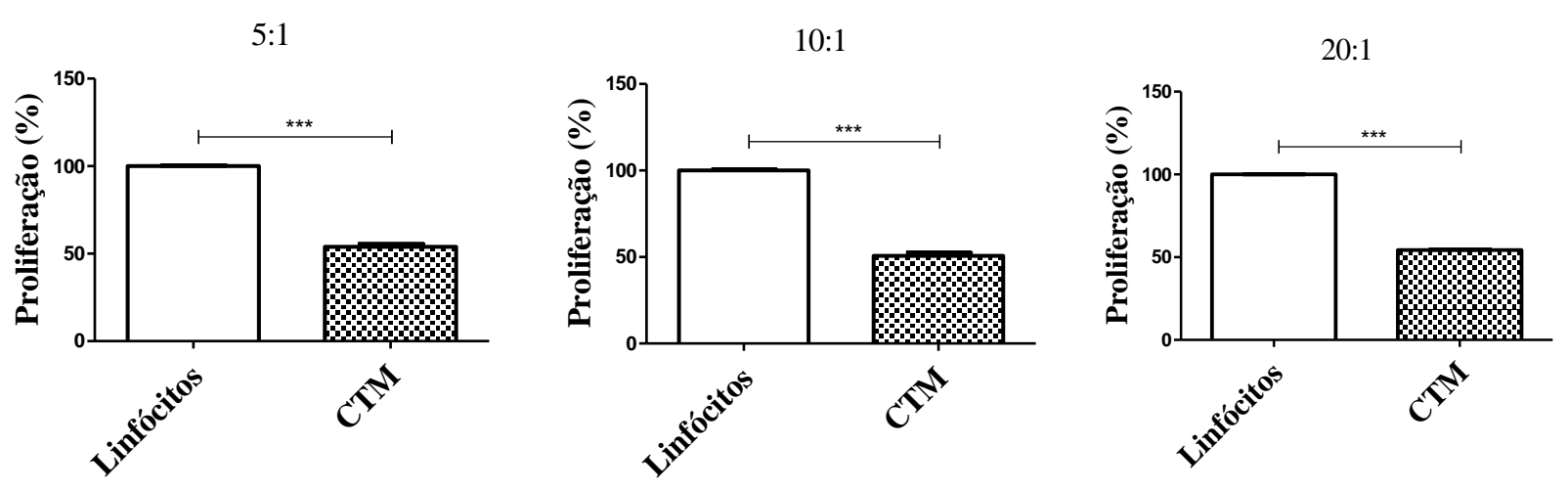

(B)

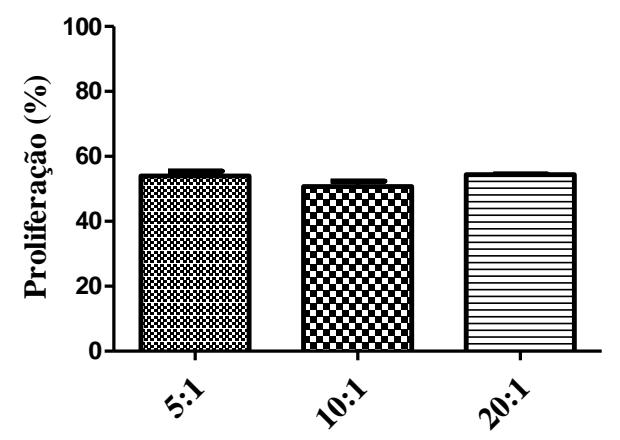

Figura 16. Padronização da razão linfócitos:CTM para o ensaio de imunossupressão. Comparações acerca da proliferação do controle positivo (linfócitos) e linfócitos co-cultivados com CTM (CTM) em razões de 5:1, 10:1 e 20:1 (A). Comparação entre a proliferação dos linfócitos co-cultivados com CTM a razões de 5:1, 10:1 e 20:1 (B). *diferença estatisticamente significativa $(\mathrm{p}<0.05)$.

\subsection{A modulação da imunossupressão exercida por agonistas de receptores do Tipo Toll}

Tendo em vista a elevada quantidade de ligantes para receptores do tipo Toll a serem avaliados, inicialmente foi realizado uma triagem em triplicata experimental (utilizando CTM derivadas de apenas um paciente), no sentido de avaliar alterações na imunossupressão decorrentes do estímulo com diversos agonistas de TLR. Para tanto, foi realizado um ensaio de imunosupressão de CTM estimuladas ou não com os ligantes: LPS, POLY IC, DSP30, CpG-A e CpG-B, a uma razão de co-cultivo linfócitos:CTM de 10:1 e por um período de 5 dias.

Além de corroborar nossos experimentos anteriores acerca da atividade imunossupressora das CTM não estimuladas, os resultados deste experimento indicam que esta atividade é prejudicada pela ação do LPS, tendo em vista que o estímulo deste ligante 
resulta na proliferação dos linfócitos a níveis semelhantes ao observado na ausência das CTM. De outro modo, a estimulação com o oligonucleotídeo CpG: DSP30 resultou no aprimoramento significativo da imunossupressão. Não foram observados efeitos significativos decorrentes dos estímulos com o POLY IC e outros oligonucleotídeos $\mathrm{CpG}$, tais como CpG-A e CpG-B (Figura 17).

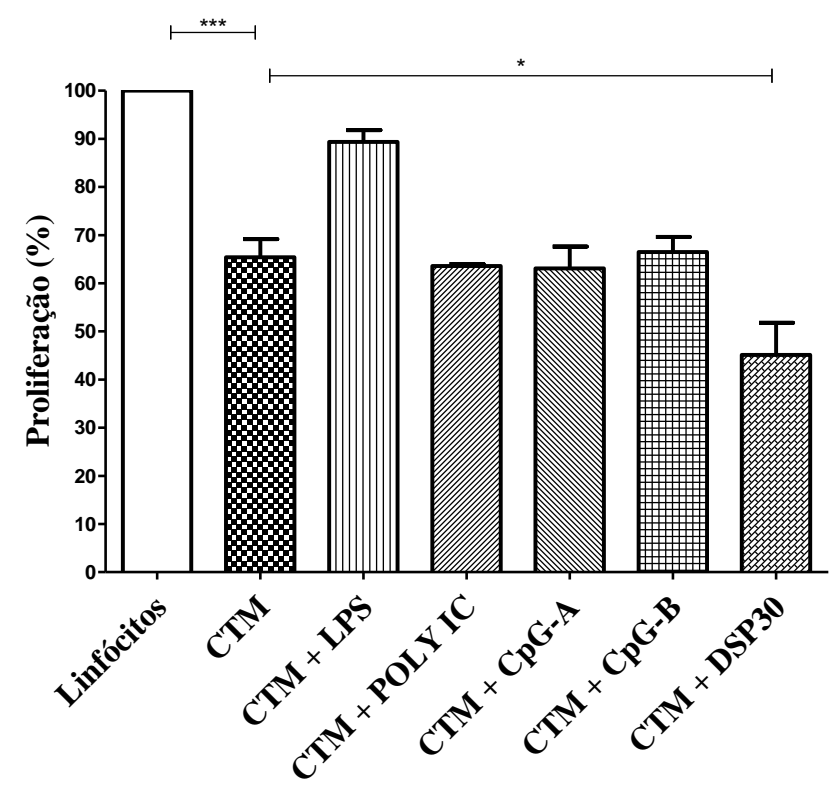

Figura 17. Gráfico acerca da triagem em triplicata experimental comparando a proliferação do controle positivo (Linfócitos) e de linfócitos co-cultivados com CTM não tratadas (CTM), ou estimuladas com LPS (CTM + LPS), POLY IC (CTM + POLY IC), CpG-A (CTM + CpG-A), CpG-B (CTM + CpG-B) ou DSP30 (CTM + DSP30). *diferença estatisticamente significativa $(\mathrm{p}<0.05)$.

No intuito de corroborar estes resultados com o uso de réplicas biológicas, um total de 4 amostras de diferentes doadores foram selecionadas para o ensaio de imunossupressão. Deste modo, as CTM foram estimuladas ou não $(n=3)$ com os ligantes: LPS e DSP30, por 24 horas. Após este período, foi realizado o co-cultivo com linfócitos a uma razão de 10:1 linfócitos:CTM e por um período de 5 dias.

Os resultados deste experimento corroboraram o que foi observado pela triagem inicial em triplicatas experimentais, tendo em vista a perda da imunossupressão em virtude do estímulo com LPS, bem como sua acentuação devido ao estímulo com DSP30. Adicionalmente, foi observado que o estímulo conjunto de LPS e DSP30 resultou na 
manutenção da imunossupressão a níveis normais, o que indica o potencial do DSP30 não apenas em acentuar esta atividade, mas também em reverter a ação do LPS (figura 18).

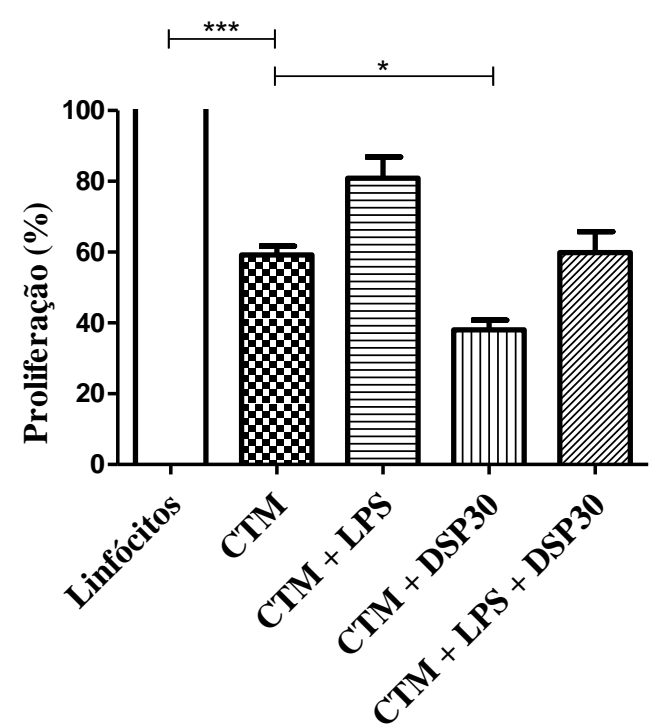

Figura 18. Gráfico representando o ensaio de imunossupressão em triplicata biológica, comparando a proliferação observada no controle positivo (Linfócitos) e linfócitos co-cultivados com CTM não tratadas (CTM) ou estimuladas com LPS (CTM + LPS), DSP30 (CTM + DSP30) ou com LPS e DSP30 simultaneamente (CTM + LPS + DSP30). *diferença estatisticamente significativa $(\mathrm{p}<0.05)$.

\subsection{Alterações na proliferação celular - High Content Screening (HCS)}

Tendo em vista a heterogeneidade de constructos de CpG ODNs, bem como de seus efeitos em induzir a proliferação em células do sistema imune, uma possível indução para a proliferação das CTM, em virtude do estímulo com DSP30, poderia estar relacionado ao aumento da imunossupressão observada. Para avaliar a ocorrência deste fenômeno, um ensaio inicial foi realizado a partir de CTM derivadas de um paciente, sendo sujeitas ou não a estimulação com os agonistas de TLR: LPS, DSP30, CpG-A, CpG-B e POLY IC. As células marcadas com o corante intracelular CellMask ${ }^{\mathrm{TM}}$ Deep Red Stain, foram analisadas quanto a quantidade total de células, em um aparelho de HCS.

Como resultados, foi observado que apenas o agonista DSP30, mas não o LPS, POLY IC e outros ligantes de TLR9, como o CpG-A e CpG-B, foram capazes de induzir um aumento significativo na quantidade total de células (figura 19). 
(A)

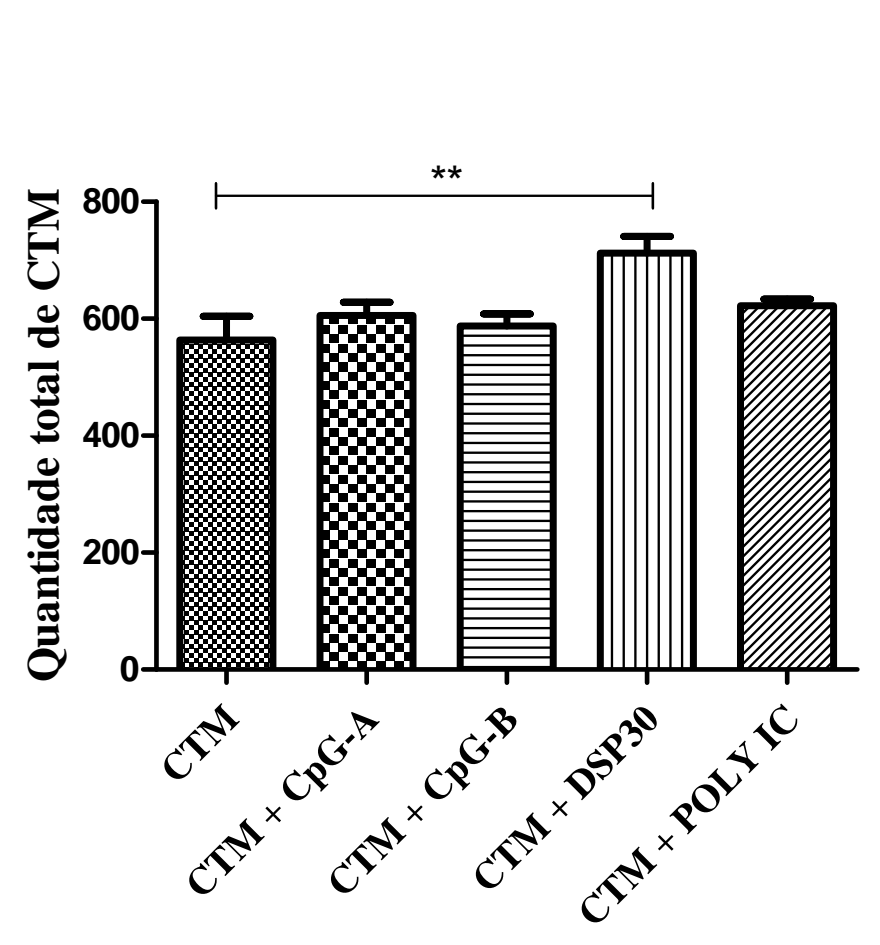

(B)

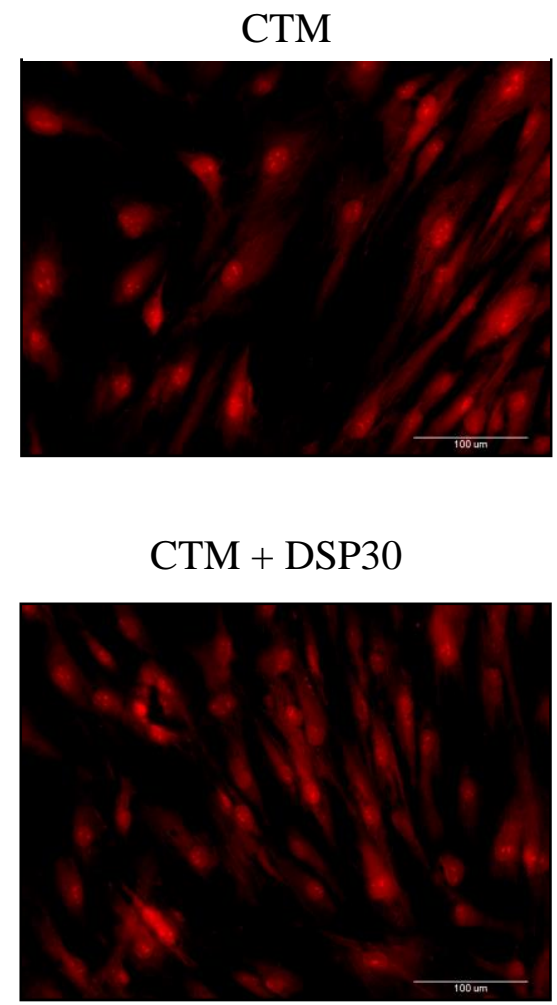

Figura 19. Alterações na proliferação celular em virtude do estímulo com agonistas de TLR. Gráfico representando o aumento significativo da quantidade das CTM tratadas com DSP30, em relação as células não tratadas (CTM) (A). Imagens representativas acerca do aumento na quantidade de células em virtude do tratamento com DSP30 (B). *diferença estatisticamente significativa $(\mathrm{p}<0.05)$.

\subsection{Alterações na proliferação celular - Síntese de DNA}

No intuito de corroborar os resultados de proliferação celular em réplicas biológicas, CTM derivadas de três doadores foram estimuladas com os agonistas de TLR: LPS, DSP30, CpG-A e CpG-B, sendo então submetidas ao kit comercial: Click-iT® EdU Alexa Fluor® 488 Flow Cytometry assay (Life Technologies; Paisley, UK), para avaliar alterações na síntese de DNA decorrente dos tratamentos, com auxílio de um aparelho de citometria de fluxo. De modo similar ao observado no ensaio de proliferação celular, foi observado que somente nas células tratadas com DSP30, houve um aumento significativo e de grande magnitude na síntese de DNA (Figura 20). 


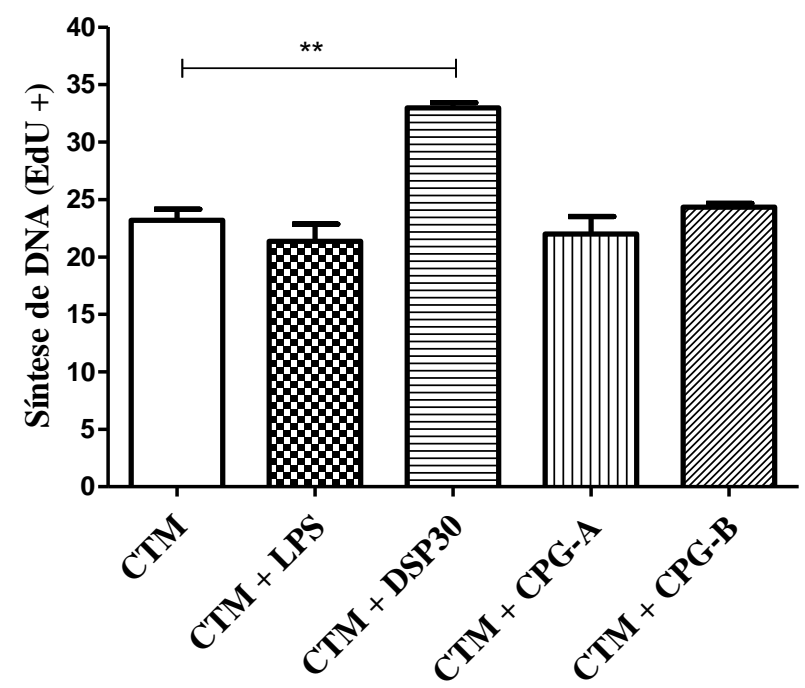

Figura 20. Alterações na síntese de DNA em virtude do estímulo com ligantes de TLR. Gráfico acerca do aumento significativo da quantidade de DNA sintetizado em virtude do estímulo com DSP30 (CTM + DSP30) em relação a CTM não estimuladas (CTM). *diferença estatisticamente significativa $(\mathrm{p}<0.05)$.

\subsection{Modulações da expressão gênica}

No intuito de avaliar a modulação da síntese de fatores relacionados a imunossupressão, as CTM foram estimuladas com agonistas de TLR, havendo extração do RNA e posterior conversão em cDNA, para então serem mensurados os níveis de expressão gênicas das citocinas IL-1 $\beta$, IL-4, IL-10 e TGF $\beta$ em reações de qPCR. Como resultados, não foram observadas a expressão das citocinas IL-4 e IL-10, nem a modulação dos seus níveis de expressão através da ação dos agonistas para TLR. De outro modo, o tratamento com LPS foi capaz de induzir um aumento significativo na síntese de IL-1 $\beta$, não alterando a expressão de TGF $\beta$, efeito contrário ao da estimulação por DSP30. Em ambos os casos, quando combinados os estímulos de LPS e DSP30, os níveis de expressão tanto de IL-1 $\beta$ quanto de TGF $\beta$ alcançaram níveis intermediários àqueles observados pelos tratamentos isoladamente (Figura 21). 
IL-1 $\beta$

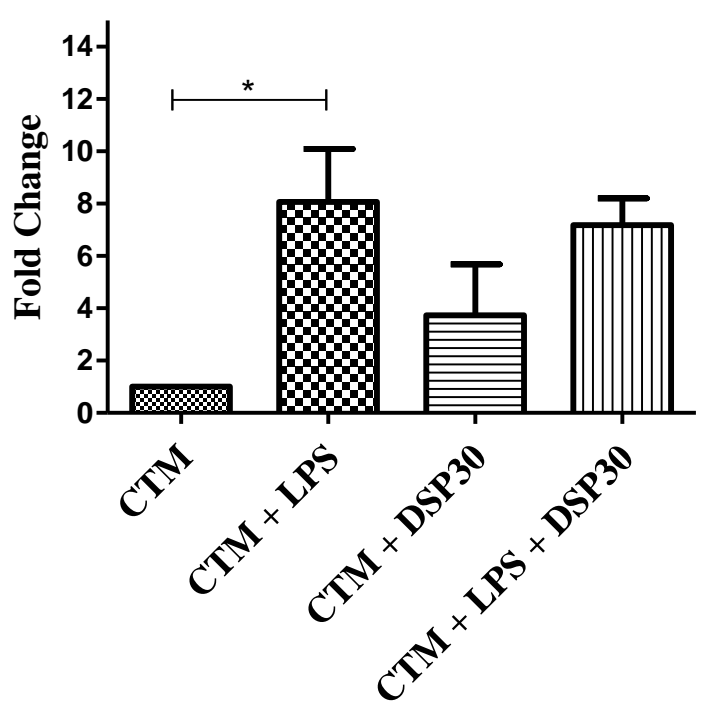

TGF $\beta$

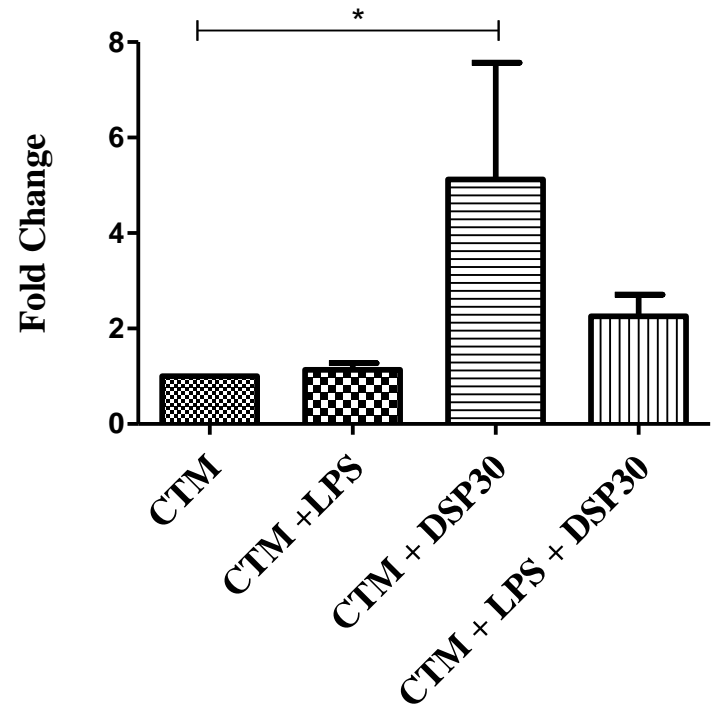

Figura 21. Gráficos representando alterações dos níveis de expressão gênica (Fold Change) de IL-1b e TGF $\beta$ entre as condições experimentais: CTM não estimuladas (CTM), estimuladas com LPS (CTM + LPS), DSP30 $(\mathrm{CTM}+\mathrm{DSP} 30)$ ou LPS e DSP30 simultaneamente (CTM + LPS + DSP30). *diferença estatisticamente significativa $(\mathrm{p}<0.05)$.

\subsection{Modulações da Atividade das vias canônica e não-Canônica NF-кB - ChIP}

Para avaliar uma possível contribuição das vias canônica e não canônica NF-ผB, na modulação da imunossupressão e expressão gênica, foi realizado um ensaio de imunoprecipitação de cromatina (ChIP), em CTM estimuladas com agonistas de TLR, com posterior ensaio de qPCR para avaliar a força de ligação dos fatores de transcrição das vias canônica e não canônica NF-kB.

Como resultados, foi observado que o estímulo por LPS resultou em um aumento na força de ligação apenas do fator de transcrição da via canônica NF-kB, enquanto o estímulo com DSP30 não alterou as forças de ligação de ambas as vias (figura 22). No entanto, o estímulo simultâneo do LPS e DSP30 resultou na ativação das vias canônica e não-canônica NF- $\kappa$ B. 


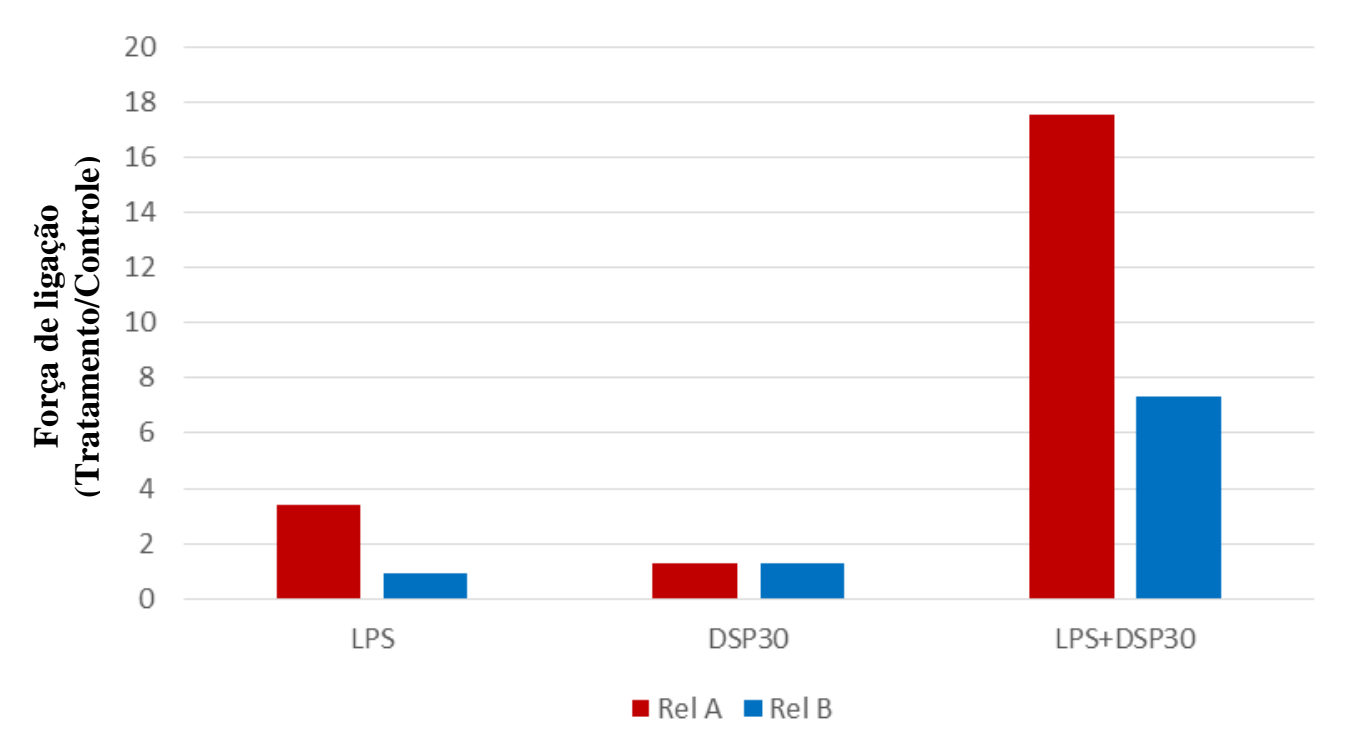

Figura 22. Modulações por agonistas de TLR, na magnitude da força de ligação dos fatores de transcrição das

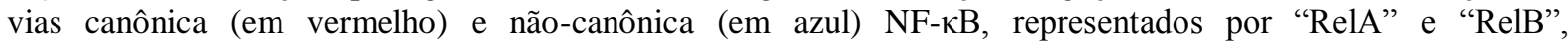
respectivamente.

\subsection{Modulações da atividade da via não canônica NF-кB - High Content Screening (HCS)}

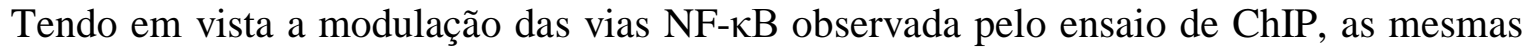
condições experimentais e período de tratamento foram reproduzidas em um ensaio de imunofluorescência, no intuito de observar a reprodutibilidade dos resultados observados,

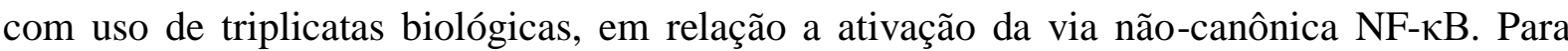
tanto, CTM foram estimuladas com os ligantes LPS e DSP30, sendo coradas nos compartimentos celulares: núcleo e citoplasma. Posteriormente, as células foram marcadas quanto a proteína RelB, sendo analisada sua presença nos compartimentos celulares com auxílio de um aparelho de HCS.

Como resultados, não foram observadas alterações na intensidade de fluorescência da proteína RelB no núcleo das células sob as condições experimentais deste ensaio. Entretanto, uma intensidade significativamente maior, embora em pequena magnitude, foi observada no citoplasma somente de células estimuladas simultaneamente com LPS e DSP30 (Figura 23), indicando que apesar de não ter sido possível mensurar uma translocação nuclear a níveis 
significativos, provavelmente este tratamento induziu a formação desta proteína em maiores magnituges.

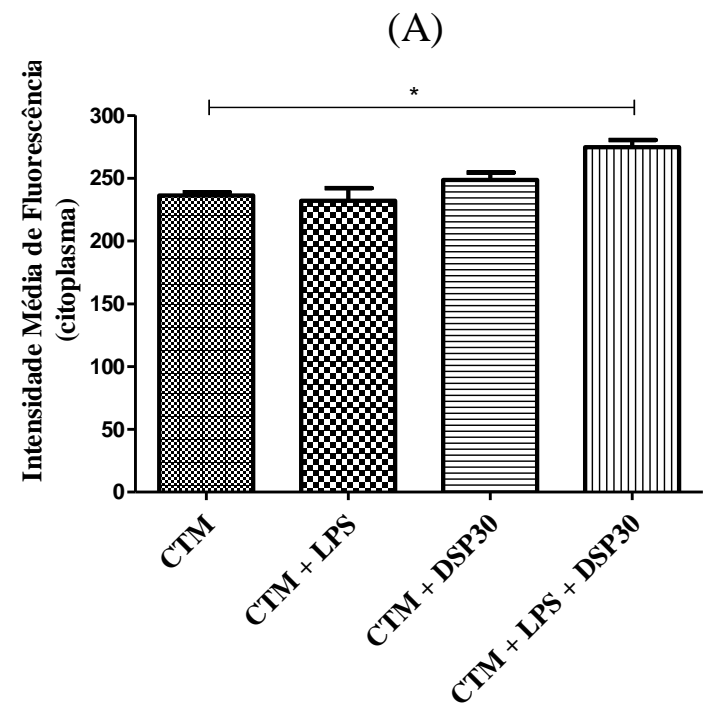

(B)
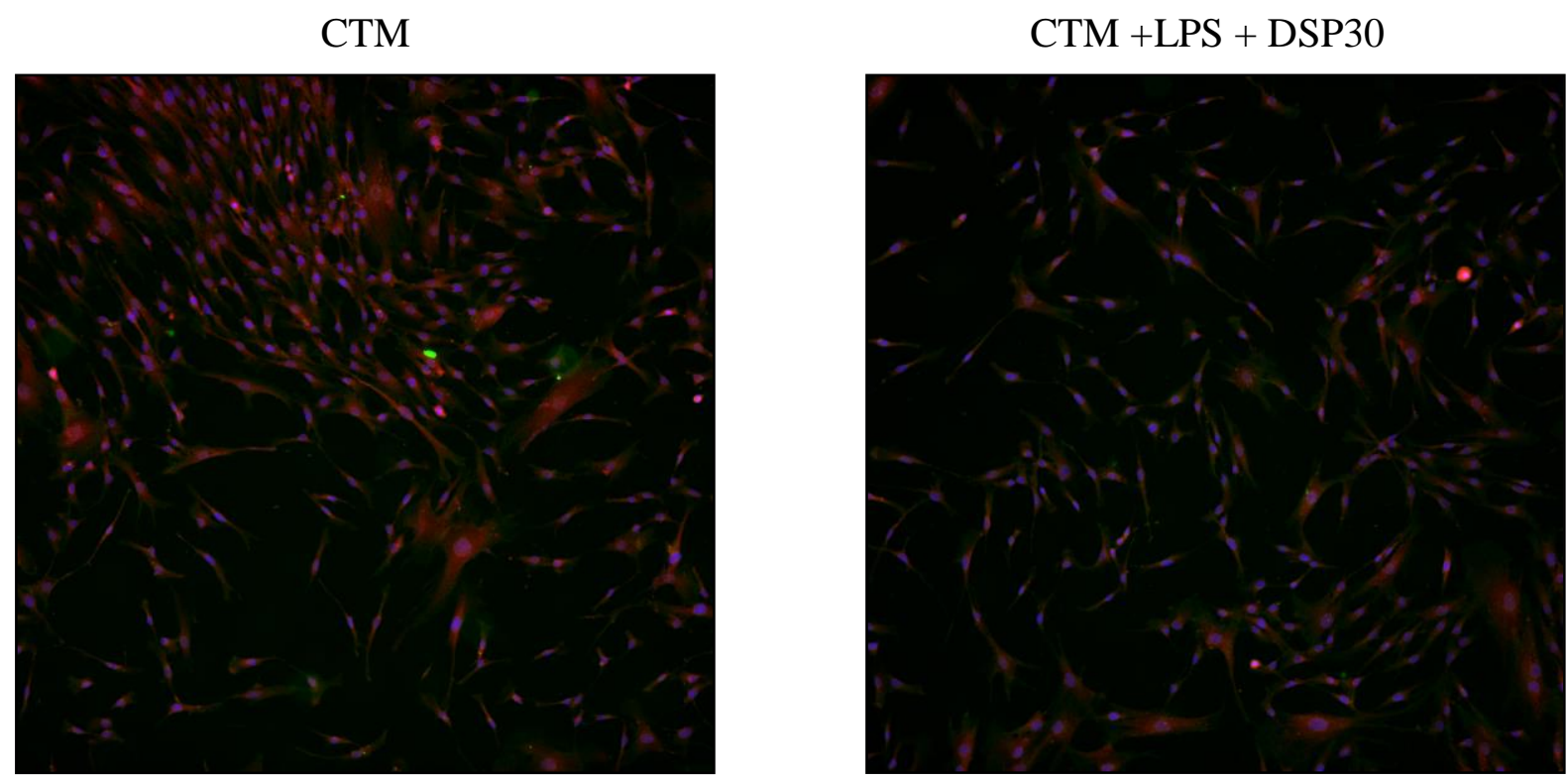

Figura 23. Gráfico da intensidade média de fluorescência no citoplasma, correspondente a proteína RelB, em CTM não estimuladas (CTM) ou estimuladas com LPS (CTM + LPS), DSP30 (CTM + DSP30) e ambos os ligantes simultaneamente (CTM + LPS + DSP30) (A). Imagens representativas acerca da intensidade de fluorescência observada em CTM não estimuladas (CTM) ou estimuladas simultaneamente com LPS e DSP30 $(\mathrm{CTM}+\mathrm{LPS}+\mathrm{DSP} 30)(\mathrm{B}) . *$ diferença estatisticamente significativa $(\mathrm{p}<0.05)$. 
Apesar das diversas fontes de obtenção, tais como medula óssea, cordão umbilical, tecido adiposo e sangue periférico, as células-tronco mesenquimais apresentam-se relativamente homogêneas quanto a sua capacidade in vitro de suprimir a proliferação de linfócitos T ativados (Saldanha-Araujo et al., 2012; Verfaillie et al., 2010; Kronsteiner et al., 2011; Sheng et al., 2008; Spaggiari et al., 2008; Zhang et al., 2008; Krampera et al., 2006; Delarosa et al., 2009). Entretanto, existe uma grande diversidade na literatura sobre os protocolos utilizados tanto para realizar co-cultivos entre CTM e linfócitos, quanto para ativar e mensurar a proliferação de linfócitos, o que provavelmente contribui para a heterogeneidade de observações encontradas acerca da modulação na imunossupressão das CTM em virtude do estímulo com agonistas para TLR. Tal variação dificulta o estabelecimento de um padrão de alterações do potencial imunossupressor, o que faz necessária a realização de mais estudos, no intuito de corroborar um mesmo fenômeno através de procedimentos diferentes.

No intuito de simular a interação entre as CTM infundidas no paciente e linfócitos ativados em virtude de desordens do sistema imune, os estudos conduzidos até o momento realizaram o co-cultivo de CTM com as PBMC derivadas de indivíduos saudáveis (Opitz et al., 2009; Waterman et al., 2010; Chen et al., 2013; Verfaillie et al., 2010; Crop et al., 2010; Raicevic et al., 2010) ou linfócitos T isolados de sangue periférico (Saldanha-Araujo et al., 2012; Liotta et al., 2008; Lombardo et al., 2009). A princípio, apesar da interação entre CTM e as diversas células do sistema imune, presentes nas PBMC, represente uma situação mais próxima a encontrada em ensaios in vivo, a sinalização entre células do sistema imune inato, moduladas através da interação com as CTM (Eggenhofer e Hoogduijn, 2012), e linfócitos ativados dificulta a atribuição dos fenômenos observados a ação exclusiva das CTM. De outro modo, o co-cultivo entre CTM e linfócitos T isolados, permite uma maior segurança em se afirmar que determinado fenômeno observado, de fato decorre de uma interação entre estas duas populações celulares. 
Além da diversidade entre protocolos de co-cultivo, diferentes técnicas de ativação dos linfócitos foram realizadas por estudos presentes na literatura até o momento, que de um modo geral compreendem na reação mista de linfócitos (MLR) (Opitz et al., 2009; Raicevic et al., 2010) ou utilização de beads acopladas a anticorpos (Saldanha-Araujo et al., 2012; Lombardo et al., 2009; Delarosa e Lombardo, 2010). A MLR compreende em induzir a ativação dos linfócitos através do co-cultivo com linfócitos ou PBMC provenientes de outro indivíduo, o que apresenta limitações quanto a possíveis interferências resultantes de interações entre ambas, apesar da maior verossimilhança quanto ao fenômeno de ativação dos linfócitos observados na DECH. De outro modo, a estimulação por beads acopladas a anticorpos proporciona a ativação de linfócitos T CD4+ e T CD8+, permitindo uma maior segurança em atribuir os efeitos observados a interações exclusivamente entre as CTM e estas populações de linfócitos, o que é particularmente verdadeiro quando realizado o co-cultivo entre CTM e linfócitos isolados.

Finalmente, para avaliar a magnitude de imunossupressão das CTM em diferentes condições experimentais, a proliferação dos linfócitos co-cultivados foi avaliada por diferentes estudos através de ensaios de incorporação de nucleosídeos (geralmente BrdU) (Saldanha-Araujo et al., 2012; Verfaillie et al., 2010; Kronsteiner et al., 2011) ou marcação intracelular por CFSE (Sheng et al., 2008; Spaggiari et al., 2008; Zhang et al., 2008). Apesar dos protocolos inerentes a tais procedimentos serem diferentes, de um modo geral a avaliação da magnitude de proliferação dos linfócitos é feita ao $5^{\circ}$ ou $6^{\circ}$ dia, sendo similares os resultados obtidos através do uso tanto do CFSE quanto do BrdU, entre estudos que utilizaram ambas as técnicas (Krampera et al., 2006; Delarosa et al., 2009).

Apesar da similaridade encontrada acerca do potencial imunossupressor das CTM derivadas de diversas fontes, os estudos clínicos realizados até o momento, de um modo geral, utilizaram CTM derivadas da medula óssea no intuito de reverter o quadro clínico de 
enfermidades do sistema imune (Connick et al., 2012; Ciccocioppo et al., 2011; Duijvestein et al., 2010; Le Blanc et al., 2008; Herrmann et al., 2012; Christensen et al., 2010). Isto pode atribuído a um maior período de tempo qual as células derivada desta fonte têm sido estudadas, tendo em vista que sua descoberta foi realizada na medula óssea (Caplan, 1991; Friedenstein et al., 1966; Friedenstein, 1980; Owen et al., 1987; Owen, 1988), proporcionando um maior conhecimento e segurança acerca de seu fenótipo e suas propriedades. Como um todo, os resultados da terapia celular utilizando CTM de medula óssea demonstraram a segurança deste procedimento, no sentido da ausência de formações de tecidos ectópicos e de neoplasias durante o tempo de observação. Apesar de seguro, a eficiência da terapia celular com CTM apresenta muitas variações com relação a sua eficácia, de acordo com os estudos clínicos realizados em larga escala em pacientes com DECH (Le Blanc et al., 2004; Le Blanc et al., 2008; Lazarus et al., 2005; Caimi et al., 2010; Kim et al., 2013).

A hipótese abordada neste trabalho, qual tais variações seriam resultado da modulação da imunossupressão em decorrência da interação com PAMPs, presentes na corrente sanguínea, encontra respaldo no fato de que vias inflamatórias e não inflamatórias podem ser moduladas através da estimulação por receptores do tipo Toll (Wingender et al., 2006; Mellor et al., 2005; Hayden, 2004). Adicionalmente, tal modulação pode resultar na polarização de fenótipos pró-inflamatório e imunossupressor em células do sistema imune inato (Mazzoni e Segal, 2004; Porta et al., 2009; Sica e Mantovani, 2012). O conhecimento acerca da imunomodulação exercida por agonistas de TLR em CTM apresenta implicações terapêuticas, tendo em vista a possibilidade de estimulação destas células, com ligantes específicos, no intuito de aprimorar ou evitar a perda da imunossupressão durante a imunoterapia.

No presente estudo, objetivamos avaliar possíveis alterações na capacidade imunorregulatória das CTM de medula óssea, decorrentes do estímulo com agonistas para 
receptores do tipo Toll. Tal avaliação foi realizada no sentido de simular uma possível interação entre as CTM infundidas e fragmentos de patógenos presentes na corrente sanguínea, decorrentes de infecções sabidamente associadas a enfermidades do sistema imune, que são alvos da imunoterapia com CTM (Jacobsohn e Vogelsang, 2007; Deeg, 2007; Goerner et al., 2002; Rahman e Isenberg, 2008; Ulff-Moller et al., 2010). Tendo em vista que a própria expressão dos TLR em CTM oriundas de diversas fontes ainda se encontra contraditória na literatura atual, realizamos também ensaios no sentido de determinar os níveis de expressão proteica em CTM derivadas de medula óssea.

Para mensurar a expressão de receptores do tipo Toll em amostras de CTM de medula óssea, células expandidas em placas de cultura celular foram avaliadas quanto aos níveis de expressão dos receptores do tipo Toll: TLR2, TLR3, TLR4 e TLR9, através da marcação com anticorpos fluorescentes, seguido da quantificação por citometria de fluxo. No presente estudo, foi observada a expressão de todos os TLR avaliados, embora tenha sido observado níveis reduzidos de expressão do TLR2 em relação aos demais receptores. Tendo em vista a expressão equivalente de todos os TLR mensurados em monócitos isolados de PBMC, é possível afirmar que este padrão de expressão dos TLR, observado em células-tronco mesenquimais de medula óssea, não decorre de uma menor afinidade do anticorpo anti-TLR2 utilizado.

Estes resultados estão de acordo com estudos anteriores, que utilizaram a técnica de citometria de fluxo para avaliar os níveis de expressão de TLR. De um modo geral, nos estudos que determinaram a presença de TLR através desta técnica, foi possível observar a distinção entre as intensidades de fluorescência do isotipo controle daquela apresentada pelo anticorpo específico, em CTM derivadas de tecido adiposo (Hwa Cho et al., 2006; Lombardo et al., 2009), medula óssea (Liotta et al., 2008; Tomchuck et al., 2008) e cordão umbilical (Chen et al., 2013). Entretanto, foi observado que o padrão de níveis de expressão dos TLR 
avaliados pelo presente trabalho obteve mais semelhança com o estudo de Cho e Colaboradores (Hwa Cho et al., 2006), no qual foi utilizado CTM derivadas de tecido adiposo, em relação ao estudo de Tomchuck e colabores (Tomchuck et al., 2008), no qual foi utilizada a medula óssea como fonte de obtenção. Isto decorre da observação de baixos níveis de expressão de TLR2 observados no estudo de Chen e colaboradores, o que não foi observado pelo estudo de Tomchuck e colaboradores. Esta dissimilaridade imunofenotípica corrobora observações anteriores de que as CTM são um grupo heterogêneo de células (Pevsner-Fischer et al., 2011; Wong, 2011; Shi et al., 2012), havendo variações fenotípicas não apenas entre fontes distintas mas entre amostras de uma mesma fonte de obtenção.

Uma vez observada a presença de diversos TLR a níveis proteicos em CTM derivadas de medula óssea, foi realizada a padronização do ensaio de imunossupressão a partir do cocultivo entre CTM e linfócitos T separados magneticamente de PBMC provenientes de doadores saudáveis, sendo então marcados com CFSE e ativados com beads acopladas a anticorpos, induzindo a ativação de linfócitos T CD4+ e T CD8+. Como resultados, foi observado que um período de 3 dias não foi suficiente para que as CTM exercessem o seu papel imunossupressor, o que pode ser atribuída a cinética de síntese e secreção de fatores solúveis imunossupressores, que somente ao $5^{\circ}$ dia de co-cultivo acumularam-se a ponto de exercer um efeito imunossupressor significativo. Adicionalmente, foi observado que a magnitude de imunossupressão das CTM permaneceu similar entre as razões CTM:Linfócitos de 5:1, 10:1 e 20:1, o que em parte está de acordo com o descrito na literatura, tendo em vista a observação por estudos anteriores da imunossupressão exercida a razões de 5:1 e 10:1 (Liotta et al., 2008; Hemeda et al., 2010), sendo observado no entanto, por Krampera e colaboradores, a perda do potencial imunossupressor em co-cultivos a razões superiores a 10:1(Krampera et al., 2006). 
Devido a limitação de material disponível para o presente estudo, o que pode ser atribuído ao procedimento invasivo inerente a coleta das CTM de medula óssea, a estratégia de uma triagem em triplicata experimental foi inicialmente realizada para avaliação das alterações na imunorregulação, decorrentes de interações com agonistas para TLR. Como resultados, observamos que o estímulo com LPS e DSP30 levaram a efeitos opostos, prejudicando e potencializando a imunorregulação das CTM, respectivamente, enquanto o estímulo por POLY IC e outros CpG ODNs não levaram a efeitos significativos. A partir destas observações, este ensaio foi repetido em triplicata biológica, sendo possível corroborar os efeitos observados para LPS e DSP30, além de ter sido observado também a manutenção da atividade normal de imunossupressão em virtude da estimulação com ambos os reagentes, o que provavelmente indica uma complementaridade dos efeitos negativos e positivos, observados nos tratamentos com estes ligantes isoladamente.

Tendo em vista as contradições presente na própria literatura, acerca da modulação da atividade imunorregulatória das CTM em virtude da estimulação com agonistas para TLR, os resultados deste trabalho corroboraram, mas também entraram em contradição com outros estudos publicados. Portanto, nossas observações acerca do efeito prejudicial do LPS encontra respaldo em estudos utilizando como fonte de obtenção as CTM de medula óssea, tais como os estudos de Liotta e colaboradores ${ }^{108}$, bem como de Waterman e colaboradores ${ }^{111}$, nos quais foram observados a perda do potencial imunossupressor das CTM, efeito contrário ao observado pelo estudo de Opitz e colaboradores ${ }^{110}$. Adicionalmente, apesar da existência de estudos na literatura nos quais não foram observados efeitos significativos na imunossupressão em virtude da estimulação com CpG-ODNs (Liotta et al., 2008; Lombardo et al., 2009; Tomchuck et al., 2008), sua potencialização foi observada recentemente pelo grupo de Chen e colaboradores (Chen et al., 2013) em CTM derivadas de cordão umbilical, embora tenha sido utilizado o $\mathrm{CpG}-\mathrm{B}$, um ligante utilizado pelo presente estudo qual não foi 
observado efeitos biológicos significativos. Neste caso, é importante destacar que as diferenças não somente entre a fonte das CTM possam ter contribuído para os diferentes efeitos observados, mas também diferenças experimentais, devido ao estudo de Chen e colaboradores ter realizado o ensaio de co-cultivo entre CTM e PBMC, induzidas a proliferação a partir da indução a mitose com fitohemaglutinina (PHA).

Tendo em vista a heterogeneidade de constructos de CpG ODN, bem como seus efeitos em induzir a proliferação em diferentes células do sistema imune (Sivori et al., 2006), foi investigado se este fenômeno poderia ocorrer também em CTM derivadas de medula óssea. Nossos resultados tanto acerca da contagem direta de células em HCS, quanto da síntese de DNA quantificada por citometria de fluxo, foram conclusivos quanto ao aumento da proliferação celular, em virtude do estímulo com DSP30. Estes resultados indicam uma possível contribuição do aumento da quantidade de células na potencialização da imunossupressão, decorrente do estímulo por DSP30, devido a disponibilidade de uma maior superfície de contato e secreção de fatores solúveis.

No intuito de investigar possíveis mecanismos moleculares inerentes a imunomodulação causada por agonistas de TLR, o nível de expressão de citocinas inflamatórias foi avaliado em CTM, sob os mesmos estímulos efetuados no ensaio de imunossupressão. Como resultados, foi encontrada a expressão e modulação das citocinas IL$1 \beta$ e TGF $\beta 1$, mas não de IL-4 e IL10. Estas observações apresentam implicações relevantes tanto em relação as interações entre CTM e linfócitos, quanto acerca de propriedades das próprias CTM.

A citocina pró-inflamatória IL-1 $\beta$ é membro de uma família de citocinas relacionadas, que sinalizam através de receptores celulares quais apresentam um domínio de imunoglobulina extracelular e um domínio citoplasmático idêntico ao dos receptores do tipoToll (Toll/IL1R) (O'neill, 2008). Deste modo, a sinalização através do receptor para IL-1 
(IL1R) leva a ativação da via dependente de MyD88 e consequentemente da via canônica NF$\kappa \mathrm{B}$, resultando na síntese de citocinas pró-inflamatórias em células do sistema imune inato, tais como macrófagos e células dendríticas (Weber et al., 2010). A presença sistêmica de IL$1 \beta$ está associada ao desenvolvimento de febre (Dinarello, 2011; Horai et al., 1998), enquanto em tecidos danificados, a estimulação de TLR e síntese de IL-1 $\beta$ está associada a exacerbação do dano tecidual, devido ao recrutamento de neutrófilos que destroem tecidos através da secreção de proteases, fosfolipases e espécies reativas de oxigênio (Bujak et al., 2008; Simi et al., 2007; Garlanda et al., 2007).

Além da sua ação em células do sistema imune inato, estudos recentes têm estabelecido que esta citocina apresenta um papel central na diferenciação de células T CD4+ em células do tipo Th17, um subconjunto de linfócitos secretores de IL-17, IL-22 e IL-26 (Mills et al., 2013; Nambu e Nakae, 2010; Mesquita Jr et al., 2009). Estas observações apresentam implicações relevantes acerca dos resultados do presente estudo, tendo em vista que a presença desta citocina está associada ao desenvolvimento de enfermidades do sistema imune que são alvos terapêuticos para imunoterapias com CTM, a exemplo da DECH (Carlson et al., 2009; Ratajczak et al., 2010; Cheng et al., 2012), esclerose múltipla (JadidiNiaragh e Mirshafiey, 2011; Lovett-Racke et al., 2011) e doença de Crohn (Brand, 2009; Waite e Skokos, 2012).

O aumento da expressão e possível síntese de IL-1 $\beta$ por CTM de medula óssea, em virtude da estimulação por LPS, está de acordo com observações anteriores (Raicevic et al., 2010; Cassatella et al., 2011), embora o estudo conduzido pelo grupo de Liotta e colaboradores não tenha observado este fenômeno (Liotta et al., 2008). De qualquer modo, este resultado fornece indícios de que o LPS circulante em pacientes com infecções bacterianas têm o potencial de mitigar o potencial imunossupressor das CTM, ao induzir a síntese de IL-1 $\beta$ e proporcionar a proliferação de linfócitos T CD4+ e T CD8+. Entretanto, a 
estimulação por outros agonistas de TLR pode exercer o efeito contrário, tendo em vista a observação de que o DSP30 potencializou a imunossupressão das CTM de medula óssea, induzindo a expressão de TGFß.

A família de citocinas anti-inflamatórias TGF $\beta$, da qual TGF $\beta 1$ se encontra mais expressa em seres humanos, apresenta efeitos pleiotrópicos em diversas linhagens celulares, estando envolvidas em processos fisiológicos como embriogênese (Oshimori e Fuchs, 2012; Sakaki-Yumoto et al., 2013), carcinogênese (Bierie e Moses, 2006; Katz et al., 2013) e respostas imunes (Li e Flavell, 2008; Tran, 2012). A interação com estas citocinas ocorre através do receptor de TGF $\beta$ (TGF $\beta$ R), ativando vias de sinalização distintas a exemplo da via dependente da família de fatores de transcrição SMAD, além de vias independentes de SMAD (não clássicas), que em conjunto operam na regulação de diversos genes responsáveis pelos efeitos descritos na literatura (Moustakas e Heldin, 2005; Massague e Chen, 2000; Engel et al., 1999).

A importância de TGFß1 para a manutenção da homeostase do sistema imune foi demonstrada por estudos anteriores, ao ser observada que sua ausência propicia o desenvolvimento de doenças auto-imunes, sendo a sua presença capaz revertê-las em modelos in vivo (Grewal et al., 2002; Prud'homme e Piccirillo, 2000; Shull et al., 1992). Este papel crucial na regulação do sistema imune decorre de observações acerca da atividade desta citocina em inibir a diferenciação de células T CD4+, impedindo a sua ação em desencadear respostas inflamatórias, bem como a ativação de diferenciação de linfócitos citotóxicos $\mathrm{T}$ CD8+ (Li e Flavell, 2008; Kubiczkova et al., 2012; Belladonna et al., 2009; Bommireddy e Doetschman, 2004). Deste modo, o aumento da expressão desta citocina observado nos ensaios de qPCR, além de revelar um mecanismo responsável pelo aumento da imunossupressão em decorrência da estimulação com DSP30, fornece mais indícios acerca dos efeitos benéficos do uso deste agonista em CTM destinadas a imunoterapias. 
Além de desempenhar funções relevantes no sistema imune, o grupo de Jian e colabores observou que o estímulo por TGFß1 pode resultar em um aumento na proliferação de CTM de medula óssea, fenômeno este dependente da translocação nuclear da proteína $\beta$ catenina e subsequente associação com o fato de transcrição TCF/LEF, o que foi corroborado pela indução a expressão constitutiva desta proteína nas CTM (Jian et al., 2006). Deste modo, existe a possibilidade do aumento da síntese de TGF $\beta 1$, desencadeado pelo estímulo por DSP30, ter sido responsável pelo aumento tanto da imunossupressão quanto da proliferação das CTM, como observado por ensaios conduzidos em HCS e citometria de fluxo. Esta possibilidade faz necessária a realização de mais estudos, no intuito de observar a atividade de diferentes vias de sinalização indutoras da proliferação celular, após o estímulo por TGF $\beta 1$, em CTM de medula óssea.

Tendo em vista que a ativação das vias canônica e não-canônica NF-אB tem como resultado o aumento e inibição da síntese de fatores pro-inflamatórios, respectivamente, em células do sistema imune inato (Sun, 2012; Schmukle e Walczak, 2012), a modulação destas vias foi avaliada através do ensaio de ChIP, com uso de anticorpos específicos a subunidades das proteínas RelA e RelB, componentes dos fatores de transcrição inerentes as vias NF- $\kappa \mathrm{B}$ canônica e não-canônica, respectivamente (Gilmore, 2006; Oeckinghaus e Ghosh, 2009; Ghosh et al., 2012; Sun, 2012). Para avaliar a atividade destas vias, CTM cultivadas em garrafas de cultura celular foram estimuladas com os ligantes LPS, DSP30 e com ambos simultaneamente, sendo submetidas ao ensaio de ChIP com auxílio de um produto comercial. Após a purificação do DNA IP, a magnitude de ligação destes fatores de transcrição foi avaliada através de um ensaio de qPCR utilizando primers específicos para a região promotora do gene VCAM-1, alvo da via NF-кB (Oeckinghaus e Ghosh, 2009; Sun, 2012; Siomek, 2012). 
É importante ressaltar que este ensaio necessita de uma grande quantidade de células, sendo comparativamente mais laborioso que os demais realizados neste estudo, portanto, as condições experimentais não foram avaliadas em réplicas experimentais ou biológicas. Adicionalmente a este fato, o uso de primers específicos a região promotora de somente um gene faz com que estes resultados sejam interpretados como preliminares, apesar de sugestivos e relevantes, necessitando de corroborações futuras com réplicas biológicas e uso de diversas regiões promotoras, para monitorar a modulação destas vias de forma ampla e estatisticamente significativa. Independentemente, os resultados do ensaio de ChIP indicaram que o estímulo por LPS leva a ativação exclusivamente do fator de transcrição RelA, a uma magnitude três vezes maior aquela observada nas CTM não estimuladas. Este resultado está de acordo com o observado nos ensaio de modulação da expressão gênica, tendo em vista que

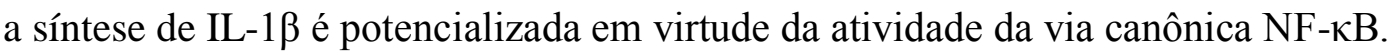

Diferente do observado para LPS, a força de ligação dos fatores de transcrição para vias canônica e não-canônica permaneceram inalterados após estímulo por DSP30, sugerindo que a enzima IDO, expressa em função da ativação da via não-canônica, pode não ter participado no aumento da imunossupressão das CTM estimuladas somente por DSP30. Entretanto, o estímulo das CTM com LPS e DSP30, resultou em um aumento de grande magnitude na ligação de RelA e RelB, indicando que somente no estímulo conjunto de ambos

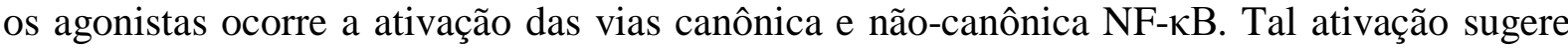
que ao serem estimuladas por LPS e DSP30, as CTM de medula óssea podem não somente aumentar a síntese de TGF $\beta$, mas também de IL-1 $\beta$ e da enzima IDO, resultando na imunossupressão a níveis normais, possivelmente devido a complementaridade de efeitos dos fatores pró-inflamatórios e anti-inflamatórios.

Devido aos resultados interessantes obtidos a partir do ensaio de ChIP, foi avaliada a atividade da via não canônica NF-אB através de ensaios de microscopia de fluorescência em 
um aparelho de HCS. Para tanto, foram formadas triplicatas biológicas de CTM, sendo cultivada em placas de 96 poços de fundo claro e estimuladas ou não com LPS, DSP30 e ambos os ligantes simultaneamente, pelo mesmo período de tratamento efetuado no ensaio de ChIP (6h). Posteriormente, as imagens adquiridas nos poços da placa de cultura celular foram analisadas acerca da magnitude de fluorescência, correspondente a presença de RelB, nos compartimentos nuclear e citoplasmático.

Como resultados, foi observado que a intensidade média de fluorescência desta proteína no compartimento nuclear permaneceu similar entre todos os tratamentos, o que não esteve de acordo com os resultados de ChIP, qual foi possível observar uma maior atividade

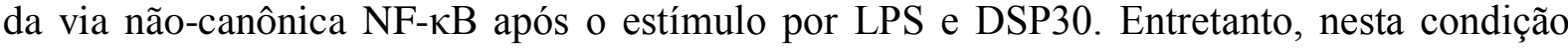
experimental foi possível observar um aumento significativo na intensidade de fluorescência de RelB no citoplasma, indicando a presença em maior magnitude do fator de transcrição para a via não-canônica neste compartimento celular. Embora uma maior presença no compartimento nuclear tenha sido esperada devido aos resultados do ensaio de ChIP, este resultado pode representar uma limitação do próprio ensaio, qual um maior período de tempo possa ser necessário para se observar um acúmulo significativo desta proteína no núcleo.

De um modo geral, os resultados deste trabalho indicam que o estímulo por diferentes TLR apresentam efeitos distintos quanto a modulação da imunossupressão em CTM de medula óssea, influenciando vias moleculares relacionadas a proliferação celular e expressão de fatores inflamatórios. Em acordo com estudos publicados recentemente, quais afirmam que as CTM podem ser "licenciadas" após o estímulo com agonistas de TLR, observamos a polarização de fenótipos de modo similar ao observado em células do sistema imune inato. Mais especificamente, através de diferentes mecanismos moleculares que ainda precisam de maior elucidação, foi observado que a estimulação por DSP30 e LPS resultaram em fenótipos acentuadamente imunossupressor ou pró-inflamatório, respectivamente. 
Como um todo, nossos resultados sugerem que a estimulação das CTM com o agonista de TLR9: DSP30, têm como efeito a indução no aumento da proliferação celular e também da expressão da citocina anti-inflamatória TGF $\beta$, resultando na acentuação da atividade imunossupressora. Do contrário, foi observado que a estimulação das CTM pelo agonista do TLR4: LPS, resultou na perda do potencial imunossupressor e aquisição de um fenótipo pró-inflamatório, como observado pelo aumento da atividade da via canônica $\mathrm{NF}-\kappa \mathrm{B}$ e síntese da citocina pró-inflamatória IL-1 $\beta$. Supreendentemente, a estimulação de ambos os agonistas foi seguida de um aumento na atividade da via não-canônica NF- $\kappa B$, o que pode ter contribuído para a manutenção da imunossupressão através de uma indução a síntese da enzima IDO.

Os resultados deste trabalho fornecem indícios de que a infusão de CTM em pacientes com infecções bacterianas pode resultar na potencialização de infecções e danos teciduais, através da indução na diferenciação de células Th17 e T CD8+, realizada por CTM polarizadas em um fenótipo pró-inflamatório. Do contrário, o tratamento com DSP30, em CTM de medula óssea expandidas em cultura e previamente a sua infusão em pacientes com doenças autoimunes ou GVHD, possivelmente irá resultar no aprimoramento do seu potencial imunossupressor, ao induzir a redução na ativação de linfócitos T CD4+ e T CD8+ (Figura 24). Todavia, os fenômenos observados nos ensaios in vitro realizados neste estudo necessitam ainda serem avaliados quanto a sua reprodutibilidade em modelos in vivo, no sentido de se estabelecer novas diretrizes de imunoterapias utilizando CTM. 


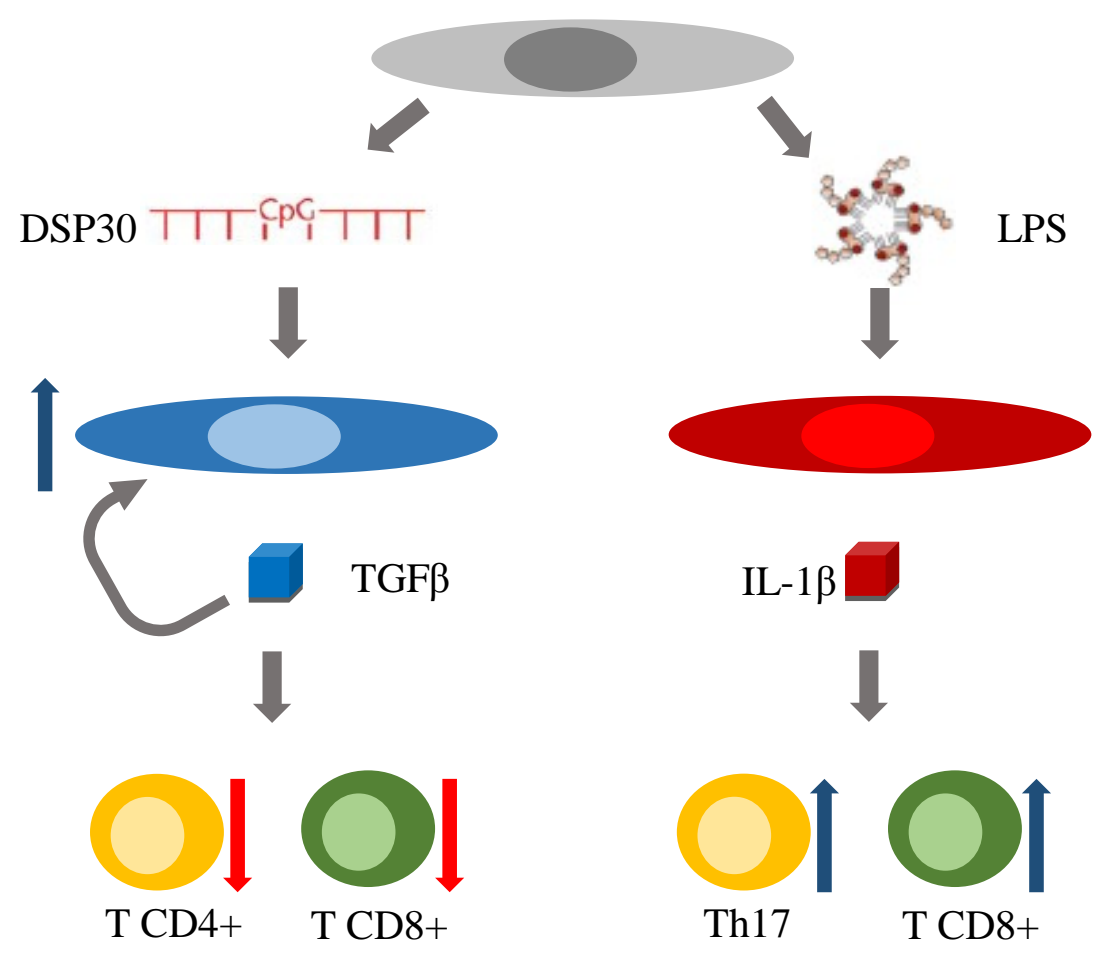

Figura 24. Ilustração acerca da polarização de fenótipos acentuadamente imunossupressor ou pró-inflamatório em virtude da estimulação com os agonistas de TLR DSP30 e LPS, respectivamente. Em destaque, está a expressão de TGF $\beta$ após estimulação por DSP30 e seu efeito em induzir a proliferação das CTM e reduzir a ativação de células T CD4+ e T CD8+. Adicionalmente, foi destacada a expressão de IL-1 $\beta$ após estimulação por LPS e seu efeito em propiciar a diferenciação de células Th17 e T CD8+. 
As principais conclusões obtidas ao decorrer da realização deste trabalho estão sumarizadas a seguir:

- As células-tronco mesenquimais de medula óssea apresentam receptores do tipo Toll funcionais.

- O estímulo do TLR4, em CTM de medula óssea, resulta na perda do potencial imunossupressor, em virtude da ativação da via canônica NF-kB e consequente síntese de citocinas inflamatórias, a exemplo de IL1 $\beta$.

- O estímulo do TLR9 via DSP30, mas não outros oligonucleotídeos com motivos CpG, resulta na indução a proliferação celular e acentuação da imunossupressão em CTM de medula óssea, ao induzir um aumento na expressão de TGF $\beta$.

- A estimulação simultânea do TLR4 e TLR9 via LPS e DSP30, respectivamente, não resulta na alteração da capacidade imunossupressora das CTM de medula óssea,

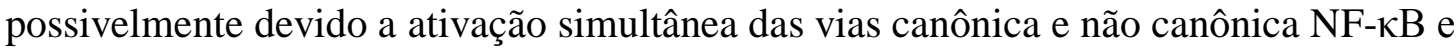
síntese de citocinas pró e anti-inflamatórias. 
7. REFERÊNCIAS BIBLIOGRÁFICAS 
RAMALHO-SANTOS, M. et al. "Stemness": transcriptional profiling of embryonic and adult stem cells. Science, v. 298, n. 5593, p. 597-600, Oct 182002.

BONGSO, A.; TAN, S. Human blastocyst culture and derivation of embryonic stem cell lines. Stem Cell Rev, v. 1, n. 2, p. 87-98, 2005.

MARTINEZ-AGOSTO, J. A. et al. The hematopoietic stem cell and its niche: a comparative view. Genes Dev, v. 21, n. 23, p. 3044-60, Dec 12007.

UCCELLI, A.; MORETTA, L.; PISTOIA, V. Mesenchymal stem cells in health and disease. Nat Rev Immunol, v. 8, n. 9, p. 726-36, Sep 2008.

CHONG, J. J. et al. Adult cardiac-resident MSC-like stem cells with a proepicardial origin. Cell Stem Cell, v. 9, n. 6, p. 527-40, Dec 22011.

KAJSTURA, J. et al. Evidence for human lung stem cells. N Engl J Med, v. 364, n. 19, p. 1795806, May 122011.

SNIPPERT, H. J.; CLEVERS, H. Tracking adult stem cells. EMBO Rep, v. 12, n. 2, p. 113-22, Feb 2011.

CIVIN, C. I. et al. Antigenic analysis of hematopoiesis. III. A hematopoietic progenitor cell surface antigen defined by a monoclonal antibody raised against KG-1a cells. J Immunol, v. 133, n. 1, p. 157-65, Jul 1984.

DIGIUSTO, D. et al. Human fetal bone marrow early progenitors for $T$, B, and myeloid cells are found exclusively in the population expressing high levels of CD34. Blood, v. 84, n. 2, p. 421-32, Jul 151994.

KRAUSE, D. S. et al. CD34: structure, biology, and clinical utility. Blood, v. 87, n. 1, p. 1-13, Jan 11996.

PASSWEG, J. R. et al. Hematopoietic stem cell transplantation: a review and recommendations for follow-up care for the general practitioner. Swiss Med Wkly, v. 142, p. w13696, 2012.

DEANS, R. J.; MOSELEY, A. B. Mesenchymal stem cells: biology and potential clinical uses. Exp Hematol, v. 28, n. 8, p. 875-84, Aug 2000.

CAPLAN, A. I. Mesenchymal stem cells. J Orthop Res, v. 9, n. 5, p. 641-50, Sep 1991. 
STEWART, M. C.; STEWART, A. A. Mesenchymal stem cells: characteristics, sources, and mechanisms of action. Vet Clin North Am Equine Pract, v. 27, n. 2, p. 243-61, Aug 2011.

DOMINICl, M. et al. Minimal criteria for defining multipotent mesenchymal stromal cells. The International Society for Cellular Therapy position statement. Cytotherapy, v. 8, n. 4, p. 315-7, 2006.

COVAS, D. T. et al. Isolation and culture of umbilical vein mesenchymal stem cells. Braz J Med Biol Res, v. 36, n. 9, p. 1179-83, Sep 2003.

DE UGARTE, D. A. et al. Differential expression of stem cell mobilization-associated molecules on multi-lineage cells from adipose tissue and bone marrow. Immunol Lett, v. 89, n. 2-3, p. 267-70, Oct 312003.

PANEPUCCI, R. A. et al. Comparison of Gene Expression of Umbilical Cord Vein and Bone Marrow-Derived Mesenchymal Stem Cells. Stem Cells, v. 22, n. 7, p. 1263-1278, 2004.

JACKSON, W. M.; NESTI, L. J.; TUAN, R. S. Potential therapeutic applications of musclederived mesenchymal stem and progenitor cells. Expert Opin Biol Ther, v. 10, n. 4, p. 505-17, Apr 2010.

WAKITANI, S.; SAITO, T.; CAPLAN, A. I. Myogenic cells derived from rat bone marrow mesenchymal stem cells exposed to 5-azacytidine. Muscle Nerve, v. 18, n. 12, p. 1417-26, Dec 1995.

PLANAT-BENARD, $V$. et al. Spontaneous cardiomyocyte differentiation from adipose tissue stroma cells. Circ Res, v. 94, n. 2, p. 223-9, Feb 62004.

MARTIN-RENDON, E. et al. 5-Azacytidine-treated human mesenchymal stem/progenitor cells derived from umbilical cord, cord blood and bone marrow do not generate cardiomyocytes in vitro at high frequencies. Vox Sang, v. 95, n. 2, p. 137-48, Aug 2008.

FERRARI, G. et al. Muscle regeneration by bone marrow-derived myogenic progenitors. Science, v. 279, n. 5356, p. 1528-30, Mar 61998.

ORLIC, D. et al. Bone marrow cells regenerate infarcted myocardium. Nature, v. 410, n. 6829, p. 701-5, Apr 52001.

ALVAREZ-DOLADO, M. et al. Fusion of bone-marrow-derived cells with Purkinje neurons, cardiomyocytes and hepatocytes. Nature, v. 425, n. 6961, p. 968-73, Oct 302003. 
ACQUISTAPACE, A. et al. Human mesenchymal stem cells reprogram adult cardiomyocytes toward a progenitor-like state through partial cell fusion and mitochondria transfer. Stem Cells, v. 29, n. 5, p. 812-24, May 2011.

KOURIS, N. A. et al. Directed Fusion of Mesenchymal Stem Cells with Cardiomyocytes via VSV-G Facilitates Stem Cell Programming. Stem Cells Int, v. 2012, p. 414038, 2012.

PACARY, E. et al. Synergistic effects of $\mathrm{CoCl}(2)$ and ROCK inhibition on mesenchymal stem cell differentiation into neuron-like cells. J Cell Sci, v. 119, n. Pt 13, p. 2667-78, Jul 12006.

HAYASHI, T. et al. Autologous mesenchymal stem cell-derived dopaminergic neurons function in parkinsonian macaques. J Clin Invest, v. 123, n. 1, p. 272-84, Jan 22013.

SNYKERS, S. et al. In vitro differentiation of embryonic and adult stem cells into hepatocytes: state of the art. Stem Cells, v. 27, n. 3, p. 577-605, Mar 2009.

HAN, J. Y. et al. Cotransplantation of cord blood hematopoietic stem cells and cultureexpanded and GM-CSF-/SCF-transfected mesenchymal stem cells in SCID mice. J Korean Med Sci, v. 22, n. 2, p. 242-7, Apr 2007.

SUGIYAMA, T. et al. Maintenance of the hematopoietic stem cell pool by CXCL12-CXCR4 chemokine signaling in bone marrow stromal cell niches. Immunity, v. 25 , n. 6, p. 977-88, Dec 2006.

BERNSTEIN, A. et al. The murine W/c-kit and Steel loci and the control of hematopoiesis. Semin Hematol, v. 28, n. 2, p. 138-42, Apr 1991.

LI, T.; WU, Y. Paracrine molecules of mesenchymal stem cells for hematopoietic stem cell niche. Bone Marrow Res, v. 2011, p. 353878, 2011.

CARRANCIO, S. et al. Bone marrow mesenchymal stem cells for improving hematopoietic function: an in vitro and in vivo model. Part 2: Effect on bone marrow microenvironment. PLoS One, v. 6, n. 10, p. e26241, 2011.

ZHAO, E. et al. Bone marrow and the control of immunity. Cell Mol Immunol, v. 9, n. 1, p. 11-9, Jan 2012.

GERMAIN, R. N. T-cell development and the CD4-CD8 lineage decision. Nat Rev Immunol, v. 2, n. 5, p. 309-22, May 2002.

BARDA-SAAD, M. et al. Adhesion of thymocytes to bone marrow stromal cells: regulation by bFGF and IFN-gamma. Stem Cells, v. 15, n. 3, p. 229-36, 1997. 
BARDA-SAAD, $M$. et al. Adhesion molecules involved in the interactions between early T cells and mesenchymal bone marrow stromal cells. Exp Hematol, v. 27, n. 5, p. 834-44, May 1999.

$\mathrm{LI}, \mathrm{Y}$. et al. Evidence for migration of donor bone marrow stromal cells into recipient thymus after bone marrow transplantation plus bone grafts: A role of stromal cells in positive selection. Exp Hematol, v. 28, n. 8, p. 950-60, Aug 2000.

DI NICOLA, M. Human bone marrow stromal cells suppress T-lymphocyte proliferation induced by cellular or nonspecific mitogenic stimuli. Blood, v. 99, n. 10, p. 3838-3843, 2002.

ZHANG, W. et al. Effects of mesenchymal stem cells on differentiation, maturation, and function of human monocyte-derived dendritic cells. Stem Cells Dev, v. 13, n. 3, p. 263-71, Jun 2004.

NEMETH, K. et al. Bone marrow stromal cells attenuate sepsis via prostaglandin E(2)dependent reprogramming of host macrophages to increase their interleukin-10 production. Nat Med, v. 15, n. 1, p. 42-9, Jan 2009.

YAGI, H. et al. Mesenchymal Stem Cells: Mechanisms of Immunomodulation and Homing. Cell Transplantation, v. 19, n. 6, p. 667-679, 2010.

BASSI, E. J.; AITA, C. A.; CAMARA, N. O. Immune regulatory properties of multipotent mesenchymal stromal cells: Where do we stand? World J Stem Cells, v. 3, n. 1, p. 1-8, Jan 26 2011.

SOLEYMANINEJADIAN, E.; PRAMANIK, K.; SAMADIAN, E. Immunomodulatory properties of mesenchymal stem cells: cytokines and factors. Am J Reprod Immunol, v. 67, n. 1, p. 1-8, Jan 2012.

MELLOR, A. L.; MUNN, D. H. Tryptophan catabolism and T-cell tolerance: immunosuppression by starvation? Immunol Today, v. 20, n. 10, p. 469-73, Oct 1999.

SALDANHA-ARAUJO, F. et al. Mesenchymal stem cells promote the sustained expression of CD69 on activated T lymphocytes: roles of canonical and non-canonical NF-KB signalling. Journal of Cellular and Molecular Medicine, v. 16, n. 6, p. 1232-1244, 2012.

SALDANHA-ARAUJO, F. et al. Mesenchymal stromal cells up-regulate CD39 and increase adenosine production to suppress activated T-lymphocytes. Stem Cell Res, v. 7, n. 1, p. 6674, Jul 2011. 
RUPPELT, A. et al. Inhibition of $T$ cell activation by cyclic adenosine $5^{\prime}$-monophosphate requires lipid raft targeting of protein kinase $A$ type I by the A-kinase anchoring protein ezrin. J Immunol, v. 179, n. 8, p. 5159-68, Oct 152007.

RAMSTAD, $C$. et al. CAMP-dependent protein kinase (PKA) inhibits $T$ cell activation by phosphorylating ser-43 of raf-1 in the MAPK/ERK pathway. Cell Signal, v. 12, n. 8, p. 557-63, Aug 2000.

FRANQUESA, M. et al. Immunomodulatory effect of mesenchymal stem cells on B cells. Front Immunol, v. 3, p. 212, 2012.

UCCELLI, A.; LARONI, A.; FREEDMAN, M. S. Mesenchymal stem cells as treatment for MS progress to date. Mult Scler, v. 19, n. 5, p. 515-9, Apr 2013.

PAPADOPOULOU, A. et al. Mesenchymal stem cells are conditionally therapeutic in preclinical models of rheumatoid arthritis. Ann Rheum Dis, v. 71, n. 10, p. 1733-40, Oct 2012.

CONNICK, P. et al. Autologous mesenchymal stem cells for the treatment of secondary progressive multiple sclerosis: an open-label phase $2 a$ proof-of-concept study. Lancet Neurol, v. 11, n. 2, p. 150-6, Feb 2012.

CICCOCIOPPO, R. et al. Autologous bone marrow-derived mesenchymal stromal cells in the treatment of fistulising Crohn's disease. Gut, v. 60, n. 6, p. 788-98, Jun 2011.

CARRION, F. A.; FIGUEROA, F. E. Mesenchymal stem cells for the treatment of systemic lupus erythematosus: is the cure for connective tissue diseases within connective tissue? Stem Cell Res Ther, v. 2, n. 3, p. 23, 2011.

MAO, F. et al. Immunosuppressive effects of mesenchymal stem cells in collagen-induced mouse arthritis. Inflamm Res, v. 59, n. 3, p. 219-25, Mar 2010.

DUIJVESTEIN, M. et al. Autologous bone marrow-derived mesenchymal stromal cell treatment for refractory luminal Crohn's disease: results of a phase I study. Gut, v. 59, n. 12, p. 1662-9, Dec 2010.

ZHOU, K. et al. Transplantation of human bone marrow mesenchymal stem cell ameliorates the autoimmune pathogenesis in MRL/Ipr mice. Cell Mol Immunol, v. 5, n. 6, p. 417-24, Dec 2008.

CHEN, F. H.; TUAN, R. S. Mesenchymal stem cells in arthritic diseases. Arthritis Res Ther, v. 10, n. 5, p. 223, 2008. 
TOLAR, J.; VILLENEUVE, P.; KEATING, A. Mesenchymal stromal cells for graft-versus-host disease. Hum Gene Ther, v. 22, n. 3, p. 257-62, Mar 2011.

LE BLANC, K. et al. Treatment of severe acute graft-versus-host disease with third party haploidentical mesenchymal stem cells. Lancet, v. 363, n. 9419, p. 1439-41, May 12004.

WEISDORF, D. GVHD the nuts and bolts. Hematology Am Soc Hematol Educ Program, p. 627, 2007.

JACOBSOHN, D. A.; VOGELSANG, G. B. Acute graft versus host disease. Orphanet Journal of Rare Diseases, v. 2, n. 1, p. 35, 2007.

SUN, L. et al. Mesenchymal stem cell transplantation reverses multiorgan dysfunction in systemic lupus erythematosus mice and humans. Stem Cells, v. 27, n. 6, p. 1421-32, Jun 2009.

GARCIA-OLMO, D. et al. Expanded adipose-derived stem cells for the treatment of complex perianal fistula: a phase II clinical trial. Dis Colon Rectum, v. 52, n. 1, p. 79-86, Jan 2009.

LE BLANC, K. et al. Mesenchymal stem cells for treatment of steroid-resistant, severe, acute graft-versus-host disease: a phase II study. The Lancet, v. 371, n. 9624, p. 1579-1586, 2008.

LAZARUS, H. M. et al. Cotransplantation of HLA-identical sibling culture-expanded mesenchymal stem cells and hematopoietic stem cells in hematologic malignancy patients. Biol Blood Marrow Transplant, v. 11, n. 5, p. 389-98, May 2005.

CAIMI, P. F. et al. Emerging therapeutic approaches for multipotent mesenchymal stromal cells. Curr Opin Hematol, v. 17, n. 6, p. 505-13, Nov 2010.

$\mathrm{KIM}, \mathrm{N}$. et al. Mesenchymal stem cells for the treatment and prevention of graft-versus-host disease: experiments and practice. Ann Hematol, v. 92, n. 10, p. 1295-308, Oct 2013.

DEEG, H. J. How I treat refractory acute GVHD. Blood, v. 109, n. 10, p. 4119-26, May 152007.

GOERNER, M. et al. Morbidity and mortality of chronic GVHD after hematopoietic stem cell transplantation from HLA-identical siblings for patients with aplastic or refractory anemias. Biol Blood Marrow Transplant, v. 8, n. 1, p. 47-56, 2002.

ADEREM, A.; ULEVITCH, R. J. Toll-like receptors in the induction of the innate immune response. Nature, v. 406, n. 6797, p. 782-7, Aug 172000. 
WEST, A. P.; KOBLANSKY, A. A.; GHOSH, S. Recognition and signaling by toll-like receptors. Annu Rev Cell Dev Biol, v. 22, p. 409-37, 2006.

MCGETTRICK, A. F.; O'NEILL, L. A. J. Localisation and trafficking of Toll-like receptors: an important mode of regulation. Current Opinion in Immunology, v. 22, n. 1, p. 20-27, 2010.

BLASIUS, A. L.; BEUTLER, B. Intracellular Toll-like Receptors. Immunity, v. 32, n. 3, p. 305-315, 2010.

TAKEDA, K.; AKIRA, S. Toll-like receptors in innate immunity. Int Immunol, v. 17, n. 1, p. 1-14, Jan 2005.

KAISHO, T.; AKIRA, S. Toll-like Receptors. 2005.

UEMATSU, S.; AKIRA, S. Toll-like receptors and Type I interferons. J Biol Chem, v. 282, n. 21, p. 15319-23, May 252007.

WINGENDER, G. et al. Systemic application of CpG-rich DNA suppresses adaptive T cell immunity via induction of IDO. Eur J Immunol, v. 36, n. 1, p. 12-20, Jan 2006.

MELLOR, A. L. et al. Cutting edge: CpG oligonucleotides induce splenic CD19+ dendritic cells to acquire potent indoleamine 2,3-dioxygenase-dependent $T$ cell regulatory functions via IFN Type 1 signaling. J Immunol, v. 175, n. 9, p. 5601-5, Nov 12005.

GILMORE, T. D. Introduction to NF-kappaB: players, pathways, perspectives. Oncogene, v. 25, n. 51 , p. $6680-4$, Oct 302006.

HAYDEN, M. S. Signaling to NF- B. Genes \& Development, v. 18, n. 18, p. 2195-2224, 2004.

OECKINGHAUS, A.; GHOSH, S. The NF- B Family of Transcription Factors and Its Regulation. Cold Spring Harbor Perspectives in Biology, v. 1, n. 4, p. a000034-a000034, 2009.

GHOSH, G. et al. NF-kappaB regulation: lessons from structures. Immunol Rev, v. 246, n. 1, p. 36-58, Mar 2012.

BISWAS, S. K.; LEWIS, C. E. NF-kappaB as a central regulator of macrophage function in tumors. J Leukoc Biol, v. 88, n. 5, p. 877-84, Nov 2010.

SUN, S. C. The noncanonical NF-kappaB pathway. Immunol Rev, v. 246, n. 1, p. 125-40, Mar 2012. 
HWA CHO, H.; BAE, Y. C.; JUNG, J. S. Role of Toll-Like Receptors on Human Adipose-Derived Stromal Cells. Stem Cells, v. 24, n. 12, p. 2744-2752, 2006.

LIOTTA, F. et al. Toll-Like Receptors 3 and 4 Are Expressed by Human Bone Marrow-Derived Mesenchymal Stem Cells and Can Inhibit Their T-Cell Modulatory Activity by Impairing Notch Signaling. Stem Cells, v. 26, n. 1, p. 279-289, 2008.

LOMBARDO, E. et al. Toll-like receptor-mediated signaling in human adipose-derived stem cells: implications for immunogenicity and immunosuppressive potential. Tissue Eng Part A, v. 15, n. 7, p. 1579-89, Jul 2009.

OPITZ, C. A. et al. Toll-Like Receptor Engagement Enhances the Immunosuppressive Properties of Human Bone Marrow-Derived Mesenchymal Stem Cells by Inducing Indoleamine-2,3-dioxygenase-1 via Interferon- $\beta$ and Protein Kinase R. Stem Cells, v. 27, n. 4, p. 909-919, 2009.

WATERMAN, R. S. et al. A new mesenchymal stem cell (MSC) paradigm: polarization into a pro-inflammatory MSC1 or an Immunosuppressive MSC2 phenotype. PLoS ONE, v. 5, n. 4, p. e10088, 2010.

TOMCHUCK, S. L. et al. Toll-Like Receptors on Human Mesenchymal Stem Cells Drive Their Migration and Immunomodulating Responses. Stem Cells, v. 26, n. 1, p. 99-107, 2008.

CHEN, D. et al. Expression and role of Toll-like receptors on human umbilical cord mesenchymal stromal cells. Cytotherapy, v. 15, n. 4, p. 423-33, Apr 2013.

SIVORI, S. et al. Comparison of different CpG oligodeoxynucleotide classes for their capability to stimulate human NK cells. Eur J Immunol, v. 36, n. 4, p. 961-7, Apr 2006.

KRUG, A. et al. Identification of $\mathrm{CpG}$ oligonucleotide sequences with high induction of IFNalpha/beta in plasmacytoid dendritic cells. Eur J Immunol, v. 31, n. 7, p. 2154-63, Jul 2001.

KRIEG, A. M. CpG motifs in bacterial DNA and their immune effects. Annu Rev Immunol, v. 20, p. 709-60, 2002.

VAN OJIK, H. H. et al. CpG-A and B oligodeoxynucleotides enhance the efficacy of antibody therapy by activating different effector cell populations. Cancer Res, v. 63, n. 17, p. 5595600, Sep 12003.

VOLLMER, J. et al. Characterization of three CpG oligodeoxynucleotide classes with distinct immunostimulatory activities. Eur J Immunol, v. 34, n. 1, p. 251-62, Jan 2004. 
SILVA, W. A., JR. et al. The profile of gene expression of human marrow mesenchymal stem cells. Stem Cells, v. 21, n. 6, p. 661-9, 2003.

VENKEN, K. et al. A CFSE based assay for measuring CD4+CD25+ regulatory T cell mediated suppression of auto-antigen specific and polyclonal T cell responses. J Immunol Methods, v. 322, n. 1-2, p. 1-11, Apr 302007.

VERFAILLIE, C. M. et al. Pro-Inflammatory Cytokines, IFNY and TNF $\alpha$, Influence Immune Properties of Human Bone Marrow and Wharton Jelly Mesenchymal Stem Cells Differentially. PLoS ONE, v. 5, n. 2, p. e9016, 2010.

KRONSTEINER, B. et al. Human Mesenchymal Stem Cells from Adipose Tissue and Amnion Influence T-Cells Depending on Stimulation Method and Presence of Other Immune Cells. Stem Cells and Development, v. 20, n. 12, p. 2115-2126, 2011.

SHENG, $\mathrm{H}$. et al. A critical role of IFNgamma in priming MSC-mediated suppression of T cell proliferation through up-regulation of B7-H1. Cell Res, v. 18, n. 8, p. 846-57, Aug 2008.

SPAGGIARI, G. M. et al. Mesenchymal stem cells inhibit natural killer-cell proliferation, cytotoxicity, and cytokine production: role of indoleamine 2,3-dioxygenase and prostaglandin E2. Blood, v. 111, n. 3, p. 1327-33, Feb 12008.

ZHANG, B. et al. Mesenchymal stem cells induce mature dendritic cells into a novel Jagged2-dependent regulatory dendritic cell population. Blood, v. 113, n. 1, p. 46-57, 2008.

KRAMPERA, M. et al. Role for Interferon- $\gamma$ in the Immunomodulatory Activity of Human Bone Marrow Mesenchymal Stem Cells. Stem Cells, v. 24, n. 2, p. 386-398, 2006.

DELAROSA, O. et al. Requirement of IFN-gamma-mediated indoleamine 2,3-dioxygenase expression in the modulation of lymphocyte proliferation by human adipose-derived stem cells. Tissue Eng Part A, v. 15, n. 10, p. 2795-806, Oct 2009.

CROP, M. J. et al. Inflammatory conditions affect gene expression and function of human adipose tissue-derived mesenchymal stem cells. Clinical \& Experimental Immunology, v. 162, n. 3, p. 474-486, 2010.

RAICEVIC, G. et al. Inflammation modifies the pattern and the function of Toll-like receptors expressed by human mesenchymal stromal cells. Human Immunology, v. 71, n. 3, p. 235244, 2010.

EGGENHOFER, E.; HOOGDUIJN, M. J. Mesenchymal stem cell-educated macrophages. Transplant Res, v. 1, n. 1, p. 12, 2012. 
DELAROSA, O.; LOMBARDO, E. Modulation of Adult Mesenchymal Stem Cells Activity by TollLike Receptors: Implications on Therapeutic Potential. Mediators of Inflammation, v. 2010, p. 1-9, 2010.

HERRMANN, R. et al. Mesenchymal stromal cell therapy for steroid-refractory acute and chronic graft versus host disease: a phase 1 study. Int J Hematol, v. 95, n. 2, p. 182-8, Feb 2012.

CHRISTENSEN, M. E. et al. Mesenchymal stromal cells transiently alter the inflammatory milieu post-transplant to delay graft-versus-host disease. Haematologica, v. 95, n. 12, p. 2102-2110, 2010.

FRIEDENSTEIN, A. J.; PIATETZKY, S., II; PETRAKOVA, K. V. Osteogenesis in transplants of bone marrow cells. J Embryol Exp Morphol, v. 16, n. 3, p. 381-90, Dec 1966.

FRIEDENSTEIN, A. J. Stromal mechanisms of bone marrow: cloning in vitro and retransplantation in vivo. Haematol Blood Transfus, v. 25, p. 19-29, 1980.

OWEN, M. E.; CAVE, J.; JOYNER, C. J. Clonal analysis in vitro of osteogenic differentiation of marrow CFU-F. J Cell Sci, v. 87 ( Pt 5), p. 731-8, Jun 1987.

OWEN, M. Marrow stromal stem cells. J Cell Sci Suppl, v. 10, p. 63-76, 1988.

MAZZONI, A.; SEGAL, D. M. Controlling the Toll road to dendritic cell polarization. J Leukoc Biol, v. 75, n. 5, p. 721-30, May 2004.

121

PORTA, C. et al. Tolerance and M2 (alternative) macrophage polarization are related processes orchestrated by p50 nuclear factor kappaB. Proc Natl Acad Sci U S A, v. 106, n. 35, p. 14978-83, Sep 12009.

SICA, A.; MANTOVANI, A. Macrophage plasticity and polarization: in vivo veritas. J Clin Invest, v. 122, n. 3, p. 787-95, Mar 12012.

RAHMAN, A.; ISENBERG, D. A. Systemic lupus erythematosus. N Engl J Med, v. 358, n. 9, p. 929-39, Feb 282008.

ULFF-MOLLER, C. J. et al. Epstein-Barr virus-associated infectious mononucleosis and risk of systemic lupus erythematosus. Rheumatology (Oxford), v. 49, n. 9, p. 1706-12, Sep 2010.

PEVSNER-FISCHER, M.; LEVIN, S.; ZIPORI, D. The origins of mesenchymal stromal cell heterogeneity. Stem Cell Rev, v. 7, n. 3, p. 560-8, Sep 2011. 
WONG, R. S. Mesenchymal stem cells: angels or demons? J Biomed Biotechnol, v. 2011, p. 459510, 2011.

$\mathrm{SHI}, \mathrm{Y}$. et al. How mesenchymal stem cells interact with tissue immune responses. Trends in Immunology, v. 33, n. 3, p. 136-143, 2012.

HEMEDA, $H$. et al. Interferon- $\gamma$ and Tumor Necrosis Factor- $\alpha$ Differentially Affect Cytokine Expression and Migration Properties of Mesenchymal Stem Cells. Stem Cells and Development, v. 19, n. 5, p. 693-706, 2010.

O'NEILL, L. A. The interleukin-1 receptor/Toll-like receptor superfamily: 10 years of progress. Immunol Rev, v. 226, p. 10-8, Dec 2008.

WEBER, A.; WASILIEW, P.; KRACHT, M. Interleukin-1 (IL-1) pathway. Sci Signal, v. 3, n. 105, p. $\mathrm{cm} 1,2010$.

DINARELLO, C. A. Interleukin-1 in the pathogenesis and treatment of inflammatory diseases. Blood, v. 117, n. 14, p. 3720-32, Apr 72011.

HORAI, R. et al. Production of mice deficient in genes for interleukin (IL)-1alpha, IL-1beta, IL1alpha/beta, and IL-1 receptor antagonist shows that IL-1beta is crucial in turpentineinduced fever development and glucocorticoid secretion. J Exp Med, v. 187, n. 9, p. 1463-75, May 41998.

BUJAK, M. et al. Interleukin-1 receptor type I signaling critically regulates infarct healing and cardiac remodeling. Am J Pathol, v. 173, n. 1, p. 57-67, Jul 2008.

SIMI, A. et al. Interleukin-1 and inflammatory neurodegeneration. Biochem Soc Trans, v. 35, n. Pt 5, p. 1122-6, Nov 2007.

GARLANDA, $C$. et al. Damping excessive inflammation and tissue damage in Mycobacterium tuberculosis infection by Toll IL-1 receptor $8 /$ single Ig IL-1-related receptor, a negative regulator of IL-1/TLR signaling. J Immunol, v. 179, n. 5, p. 3119-25, Sep 12007.

MILLS, K. H. et al. The role of inflammasome-derived IL-1 in driving IL-17 responses. J Leukoc Biol, v. 93, n. 4, p. 489-97, Apr 2013.

NAMBU, A.; NAKAE, S. IL-1 and Allergy. Allergol Int, v. 59, n. 2, p. 125-35, Jun 2010.

MESQUITA JR, D. et al. Autoimmune diseases in the TH17 era. Braz J Med Biol Res, v. 42, n. 6, p. 476-86, Jun 2009. 
CARLSON, M. J. et al. In vitro-differentiated TH17 cells mediate lethal acute graft-versus-host disease with severe cutaneous and pulmonary pathologic manifestations. Blood, v. 113, n. 6, p. 1365-74, Feb 52009.

RATAJCZAK, P. et al. Th17/Treg ratio in human graft-versus-host disease. Blood, v. 116, n. 7, p. 1165-71, Aug 192010.

CHENG, $\mathrm{H}$. et al. TH17 cells are critical for skin-specific pathological injury in acute graftversus-host disease. Transplant Proc, v. 44, n. 5, p. 1412-8, Jun 2012.

JADIDI-NIARAGH, F.; MIRSHAFIEY, A. Th17 cell, the new player of neuroinflammatory process in multiple sclerosis. Scand J Immunol, v. 74, n. 1, p. 1-13, Jul 2011.

LOVETT-RACKE, A. E.; YANG, Y.; RACKE, M. K. Th1 versus Th17: are T cell cytokines relevant in multiple sclerosis? Biochim Biophys Acta, v. 1812, n. 2, p. 246-51, Feb 2011.

BRAND, S. Crohn's disease: Th1, Th17 or both? The change of a paradigm: new immunological and genetic insights implicate Th17 cells in the pathogenesis of Crohn's disease. Gut, v. 58, n. 8, p. 1152-67, Aug 2009.

WAITE, J. C.; SKOKOS, D. Th17 response and inflammatory autoimmune diseases. Int J Inflam, v. 2012, p. 819467, 2012.

CASSATELLA, M. A. et al. Toll-Like Receptor-3-Activated Human Mesenchymal Stromal Cells Significantly Prolong the Survival and Function of Neutrophils. Stem Cells, v. 29, n. 6, p. 10011011, 2011.

OSHIMORI, N.; FUCHS, E. The harmonies played by TGF-beta in stem cell biology. Cell Stem Cell, v. 11, n. 6, p. 751-64, Dec 72012.

SAKAKI-YUMOTO, M.; KATSUNO, Y.; DERYNCK, R. TGF-beta family signaling in stem cells. Biochim Biophys Acta, v. 1830, n. 2, p. 2280-96, Feb 2013.

BIERIE, B.; MOSES, H. L. Tumour microenvironment: TGFbeta: the molecular Jekyll and Hyde of cancer. Nat Rev Cancer, v. 6, n. 7, p. 506-20, Jul 2006.

KATZ, L. H. et al. Targeting TGF-beta signaling in cancer. Expert Opin Ther Targets, v. 17, n. 7, p. 743-60, Jul 2013.

LI, M. O.; FLAVELL, R. A. TGF-beta: a master of all T cell trades. Cell, v. 134, n. 3, p. 392-404, Aug 82008. 
TRAN, D. Q. TGF-beta: the sword, the wand, and the shield of FOXP3(+) regulatory T cells. J Mol Cell Biol, v. 4, n. 1, p. 29-37, Feb 2012.

MOUSTAKAS, A.; HELDIN, C. H. Non-Smad TGF-beta signals. J Cell Sci, v. 118, n. Pt 16, p. 3573-84, Aug 152005.

MASSAGUE, J.; CHEN, Y. G. Controlling TGF-beta signaling. Genes Dev, v. 14, n. 6, p. 627-44, Mar 152000.

ENGEL, M. E. et al. Interdependent SMAD and JNK signaling in transforming growth factorbeta-mediated transcription. J Biol Chem, v. 274, n. 52, p. 37413-20, Dec 241999.

GREWAL, I. S. et al. Expression of transgene encoded TGF-beta in islets prevents autoimmune diabetes in NOD mice by a local mechanism. J Autoimmun, v. 19, n. 1-2, p. 9-22, Aug-Sep 2002.

PRUD'HOMME, G. J.; PICCIRILLO, C. A. The inhibitory effects of transforming growth factorbeta-1 (TGF-beta1) in autoimmune diseases. J Autoimmun, v. 14, n. 1, p. 23-42, Feb 2000.

SHULL, M. M. et al. Targeted disruption of the mouse transforming growth factor-beta 1 gene results in multifocal inflammatory disease. Nature, v. 359, n. 6397, p. 693-9, Oct 22 1992.

KUBICZKOVA, L. et al. TGF-beta - an excellent servant but a bad master. J Transl Med, v. 10, p. 183, 2012.

BELLADONNA, M. L. et al. TGF- $\beta$ and kynurenines as the key to infectious tolerance. Trends in Molecular Medicine, v. 15, n. 2, p. 41-49, 2009.

BOMMIREDDY, R.; DOETSCHMAN, T. TGF-beta, T-cell tolerance and anti-CD3 therapy. Trends Mol Med, v. 10, n. 1, p. 3-9, Jan 2004.

JIAN, H. et al. Smad3-dependent nuclear translocation of beta-catenin is required for TGFbeta1-induced proliferation of bone marrow-derived adult human mesenchymal stem cells. Genes Dev, v. 20, n. 6, p. 666-74, Mar 152006.

SCHMUKLE, A. C.; WALCZAK, H. No one can whistle a symphony alone - how different ubiquitin linkages cooperate to orchestrate NF- B activity. Journal of Cell Science, v. 125, n. 3, p. 549-559, 2012.

SIOMEK, A. NF-kappaB signaling pathway and free radical impact. Acta Biochim Pol, v. 59, n. 3, p. 323-31, 2012. 